THE RESPONSE OF GLACIERS TO CLIMATE CHANGE

Lisette Klok 
Dukker: PrintPartners Ipskamp, Enschede

Ontwerp omslag en concept binnenwerk: Coen Hamming, Amsterdam

ISBN 90-393-3547-8 


\section{DE REACTIE VAN GLETSJERS OP KLIMAATVERANDERING}

(met een samenvatting in het Nederlands)

Proefschrift ter verkrijging van de graad van doctor aan de Universiteit Utrecht op gezag van de Rector Magnificus,

Prof. Dr. W.H. Gispen, ingevolge het besluit van het College voor Promoties in het openbaar te verdedigen op woensdag 3 december 2003 des middags te 12.45 uur door Elisabeth Jantina Klok

geboren op 15 maart 1976, te Bennekom 
promotor: Prof. Dr. J. Oerlemans

Instituut voor Marien en Atmosferisch Onderzoek Utrecht (IMAU)

Faculteit Natuur- en Sterrenkunde, Universiteit Utrecht

paranimfen: Francien van Soest en Janneke Zinkstok

Dit proefschrift werd mogelijk gemaakt door financiële steun van de Nederlandse Organisatie voor Wetenschappelijk Onderzoek, Aard- en Levenswetenschappen (NWO-ALW). 
José Arcadio Buendia begreep hem niet en stak zijn hand uit om het geheimzinnige blok aan te raken, maar de reus duwde zijn arm weg. 'Vijf realen meer om het aan te raken,' zei hij. José Arcadio Buendia betaalde en toen legde hij zijn hand op het ijs en liet hem daar minutenlang liggen, terwijl zijn hart opzwol van angst en vervoering bij de aanraking van dit mysterie.

Hij betaalde nog vijf realen en met zijn hand op het blok ijs, alsof hij een eed aflegde op de bijbel, riep hij uit:

'Dit is de uitvinding van onze tijd!'

Uit: 'Honderd jaar eenzaamheid' van Gabriel García Márquez. 

aan mijn ouders 



\section{CONTENTS}

$\begin{array}{ll}\text { SUMMARY } & 13\end{array}$

$\begin{array}{ll}\text { SAMENVATTING } & 19\end{array}$

1 INTRODUCTION 25

1.1 GLACIERS AND CLIMATE $\quad 25$

$\begin{array}{ll}1.2 \text { BACKGROUND } & 27\end{array}$

$\begin{array}{ll}\text { 1.2.1 Glacier mass balance } & 27\end{array}$

1.2.2 Mass-balance models $\quad 30$

1.2.4 Albedo 32

1.2.5 Automatic weather stations 34

1.2.6 Glacier length fluctuations $\quad 35$

$\begin{array}{ll}\text { 1.2.7 Inverse modelling } & 37\end{array}$

1.3 CONTENTS OF THIS THESIS

$\begin{array}{ll}\text { REFERENCES } & 39\end{array}$

2 TEMPORAL AND SPATIAL VARIATION OF THE SURFACE ALBEDO OF
MORTERATSCHGLETSCHER, SWITZERLAND, AS DERIVED FROM TWELVE LANDSAT IMAGES $\quad 43$

2.1 INTRODUCTION 44

2.2 RETRIEVAL METHOD 46

2.3 UNCERTAINTIES IN THE RETRIEVAL METHOD 51

2.3.1 Topography 51

2.3.2 Radiometric calibration $\quad 52$

2.3.3 Atmospheric composition 53

2.3.4 Diffuse, direct and reflected radiation $\quad 53$

2.3.5 BRDF parameterisations 54

2.3.6 Narrow-to-broadband conversion $\quad 55$

2.4. RESULTS AND INTERPRETATION

2.4.1 Spatial distribution of the surface albedo of the entire glacier 55

2.4.2 Albedo of the ablation area $\quad 56$

2.4.3 Mean albedo over height intervals $\quad 57$

2.4.4 Albedo along two centrelines $\quad 58$ 
2.4.5 Comparison with ground measurements $\quad 60$

2.4.6 Relation between rainfall and an increase in surface albedo $\quad 61$

$\begin{array}{ll}2.5 \text { SUMMARY AND CONCLUSIONS } & 61\end{array}$

$\begin{array}{ll}\text { REFERENCES } & 63\end{array}$

\section{MODEL STUDY OF THE SPATIAL DISTRIBUTION OF THE ENERGY AND MASS BALANCE OF MORTERATSCHGLETSCHER, SWITZERLAND 67}

$\begin{array}{ll}3.1 \text { INTRODUCTION } & 68\end{array}$

$\begin{array}{ll}\text { 3.2 MORTERATSCHGLETSCHER } & 70\end{array}$

$\begin{array}{ll}3.3 \text { THE DATA } & 70\end{array}$

$\begin{array}{ll}\text { 3.4 MODEL DESCRIPTION } & 72\end{array}$

3.4.1 Incoming solar radiation $\quad 72$

$\begin{array}{ll}3.4 .2 \text { Reflected shortwave radiation } & 74\end{array}$

$\begin{array}{ll}\text { 3.4.3 Longwave radiation } & 75\end{array}$

3.4.4 Turbulent fluxes $\quad 76$

$\begin{array}{ll}\text { 3.4.5 Glacier heat flux and surface temperature } & 77\end{array}$

$\begin{array}{ll}\text { 3.4.6 Snow accumulation } & 78\end{array}$

$\begin{array}{ll}\text { 3.4.7 Snow depth } & 78\end{array}$

$\begin{array}{ll}\text { 3.5. PARAMETER SENSITIVITY } & 78\end{array}$

$\begin{array}{ll}3.6 \text { RESULTS } & 79\end{array}$

3.6.1 Comparison with observations at M1, M2 and M3 79

3.6.2 Spatial distribution of the energy fluxes and the specific mass balance $\quad 84$

3.6.3 Topographical effects on solar radiation 86

3.6.4 Energy fluxes at M1, a sunny and a shaded location $\quad 88$

3.6.5 Climate sensitivity 90

$\begin{array}{ll}\text { 3.7 CONCLUDING REMARKS } & 91\end{array}$

$\begin{array}{ll}\text { REFERENCES } & 92\end{array}$

\begin{tabular}{lr}
\hline MODELLED CLIMATE SENSITIVITY OF THE MASS BALANCE OF \\
MORTERATSCHGLETSCHER AND ITS DEPENDENCE ON ALBEDO \\
PARAMETERISATION
\end{tabular}


4.4 MASS-BALANCE CALCULATIONS FOR THE PERIOD 1980-2002 102

$\begin{array}{ll}\text { 4.5 ALBEDO PARAMETERISATIONS } & 104\end{array}$

4.5.1 Parameterisation I 104

$\begin{array}{ll}\text { 4.5.2 Parameterisation II } & 105\end{array}$

4.5.3 Parameterisation III 106

$\begin{array}{ll}\text { 4.5.4 Parameterisation IV } & 107\end{array}$

4.6 RESULTS FROM DIFFERENT ALBEDO PARAMETERISATIONS 108

4.6.1 Mass balance 108

$\begin{array}{ll}\text { 4.6.2 Mass-balance sensitivity } & 108\end{array}$

$\begin{array}{ll}4.7 \text { DISCUSSION } & 110\end{array}$

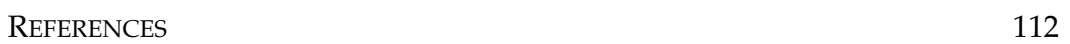

5 CLIMATE RECONSTRUCTIONS DERIVED FROM GLOBAL GLACIER
LENGTH RECORDS INCLUDING A CASE-STUDY FOR EUROPEAN $\begin{array}{ll}\text { GLACIERS } & 115\end{array}$

5.1 INTRODUCTION 116

5.2 THE ANALYTICAL MODEL 119

5.2.1 Linear response equation $\quad 119$

5.2.2 Calculation of the length response time and the climate sensitivity $\quad 121$

$\begin{array}{ll}\text { 5.3 PARAMETER SENSITIVITY } & 125\end{array}$

5.4 CASE STUDY: EUROPEAN GLACIERS 129

5.4.1 Length response time and climate-sensitivity results 129

5.4.2 Reconstructions of the equilibrium line altitude 130

5.4.3 Comparison of the results with other records 133

5.5.4 Conclusions of the case-study 136

5.5 GLOBAL GLACIERS AND THEIR LENGTH RECORDS 136

$\begin{array}{ll}\text { 5.5.1 Canada } & 138\end{array}$

5.5.2 U.S.A. 139

5.5.3 South America 139

$\begin{array}{ll}\text { 5.5.4 Europe } & 140\end{array}$

$\begin{array}{ll}\text { 5.5.5 Asia } & 140\end{array}$

5.5.6 New Zealand 141

5.6 RESULTS FOR WORLDWIDE GLACIERS 141

5.6.1 Length response times and climate sensitivities 141

$\begin{array}{ll}\text { 5.6.2 ELA reconstructions } & 142\end{array}$

5.6.3 Worldwide pattern in ELA fluctuations $\quad 142$

5.6.4 Reconstructions of temperature 144 
5.7 DISCUSSION

5.8 SUMMARY 146

REFERENCES

147

NAWOORD

151

CURRICULUM VITAE

153

LIST OF PUBLICATIONS

155 


\section{SUMMARY}

Small glaciers, which constitute all of the earth's glaciers and ice caps, except for the great ice sheets of Antarctica and Greenland, have retreated significantly during the $20^{\text {th }}$ century. Compared to the great ice sheets, small glaciers are often more sensitive to changes in climate and in addition reflect changes in climate by advancing or retreating with a much shorter time delay. In other words, small glaciers are characterised by a large climate sensitivity and a short response time. For this reason they contribute significantly to sea level rise when climate warms and also serve as good climate indicators. Information on the extent of small glaciers at different times in the past is therefore very useful for inferring information on the historical climate.

Changes in glacier length are connected to changes in climate by the mass balance of the glacier surface. The mass balance is the change in mass per unit area over a period of time. It is the sum of all processes by which snow and ice are added to the glacier and lost from the glacier, for example due to snowfall, sublimation, melting and evaporation. The amount of glacier melt depends on the surface energy balance of the glacier. The surface energy balance is, in turn, determined by the energy fluxes between the atmosphere and the glacier surface. These are the incoming and reflected solar radiation, the incoming and outgoing longwave radiation, and the sensible and latent heat fluxes. The sum of these energy fluxes is used for warming or cooling of the snow or ice pack and for melting. The solar radiation budget often plays a dominant role in the surface energy balance of a glacier. It depends largely on the reflected fraction of the incoming solar radiation, which is called albedo.

To understand the response of glaciers to changes in climate the physical processes that govern their interaction need to be studied, making use of measurements and physically based models. To translate historic length fluctuations of glaciers into information on the past climate generalised parameterisations are necessary.

The research described in this thesis addresses these two aspects. The first aspect, physical processes, was treated by studying the spatial and temporal variation of the glacier albedo from satellite images (Chapter 2), by investigating the spatial distribution of the surface energy and mass balance of a glacier using a two-dimensional mass-balance model (Chapter 3 ), and by investigating the sensitivity of the mass balance to changes in climate and its dependence on albedo parameterisation (Chapter 4). All of these studies were focused on Morteratschgletscher in Switzerland because IMAU (Institute for Marine and Atmospheric research, Utrecht) has been 
operating automatic weather stations on this glacier since 1995. The second aspect, the climatic interpretation of glacier length fluctuations, was dealt with by developing a method that calculates historical mass-balance records from global glacier length fluctuations (Chapter 5). This method was tested on European glaciers and applied to global glacier length records.

\section{PHYSICAL PROCESSES LINKING GLACIERS AND CLIMATE}

To increase our understanding of the variations in glacier albedo, we studied a large series of satellite images of Morteratschgletscher (Chapter 2). A better understanding of the glacier albedo is needed to improve the current albedo parameterisations used in energy-balance models, as they are often inadequate to represent the changes in surface albedo in space and time. We derived surface albedos from twelve Landsat images from days in 1999 and 2000. The retrieval of surface albedo from Morteratschgletscher, using Landsat images, constituted a stringent test for the methodology applied. This glacier has a very steep and rugged accumulation zone, which strongly influences the satellite signal. We aimed to retrieve surface albedos while taking into account all important processes that influence the relationship between the satellite signal and the surface albedo, e.g. the topographic effects on direct and diffuse solar radiation, and the reflected solar radiation from the surrounding terrain. As ice and snow are anisotropic reflectors, which implies that reflected radiation is not the same in all directions, we also corrected for the anisotropic nature of the reflected radiation field. To our knowledge, this has not yet been attempted before for both ice and snow surfaces. This correction can be as much as 0.10 in albedo, depending on wavelength band of the satellite sensor, solar zenith angle and surface type. We analysed uncertainties in the retrieval method and found that errors are mainly expected in satellite-derived albedos for areas with a large variation in topography and areas with high albedos. Areas with a large variation in topography show unrealistically low satellite-derived surface albedos and a larger scatter in albedo. This is associated with the accuracy of the image geolocation, which influences the estimation of the slope and aspect of each pixel, which in turn affects corrections for topography and anisotropy. The uncertainty in the surface albedo due the inaccuracy of the image geolocation was estimated at 0.05 . Application of parameterisations for the anisotropic correction to albedos outside the parameterisations' validity, mostly too high albedos, leads to uncertainties of about 0.05 . In order to improve the retrieval method, it would be useful to determine parameterisations for the anisotropic correction for a wider range of surface albedos, solar zenith angles and surface conditions. 
We compared the Landsat-derived albedo to albedo measurements from an automatic weather station on the glacier tongue. On average, satellite-derived albedos exceed the measured surface albedo with 0.03 . The satellite derived surface albedo indicates that the ice of the glacier tongue is characterised by longitudinal bands with a more or less constant albedo. A central band with an albedo of about 0.3 is flanked on both sides by bands of lower albedo (0.15). This is due to debris, the gathering of dust and rock fragments on the glacier surface. We concluded that the ice albedo does not depend on altitude. During summer, the albedo of the glacier ice increases by about 0.06 . This is most likely associated with rainfall washing away debris, as concluded from a comparison between summer rainfall and measured albedos. Concerning the parameterisations of albedo, the glacier ice albedo of Morteratschgletscher should not be parameterised as a function of altitude.

We studied the spatial distribution of the energy and mass-balance fluxes of Morteratschgletscher using a two-dimensional mass-balance model based on the surface energy balance (Chapter 3). The twodimensional mass-balance model is an improvement over earlier massbalance models, which are either zero- or one-dimensional and do not account for the full spatial variation in the energy and mass-balance fluxes. Since Morteratschgletscher is located between high mountains, we corrected incoming solar radiation for shading, aspect, slope, reflection from slopes, and obstruction of the sky. We investigated the effects of these topographical corrections on the incoming solar radiation and the mass balance. We also determined the sensitivity of the mass balance to changes in climate. We based our results on simulations of the two years 1999 and 2000. Meteorological data from four synoptic weather stations in the vicinity of Morteratschgletscher serve as input for the model instead of data from the automatic weather stations located on Morteratschgletscher. The difference between these two types of data is that instruments on the glacier measure the microclimate of the glacier boundary layer, whereas the synoptic weather stations register an atmosphere that depicts the microclimate of an alpine area. In order to study the effect of climate changes, a mass-balance model should be able to generate a mass-balance field from data that are not influenced by the glacier. We tuned the model by changing the turbulent exchange parameter, needed for calculating the sensible and latent heat fluxes, such that the calculated melt was in agreement with observed melt on the glacier tongue.

Model results are most sensitive to uncertainties in the albedo of ice, the threshold temperature between rain and snowfall, and the fractional cloud cover. The latter causes a change in the mass balance of $-0.18 \mathrm{~m}$ w.e. (water equivalent) for an increase in the fractional cloud cover of 0.2 . The modelled mass balance of Morteratschgletscher is $-0.47 \mathrm{~m}$ w.e. for 1999 and $0.23 \mathrm{~m}$ w.e. for 2000 . The energy fluxes vary mainly with elevation, but 
shortwave radiation also varies laterally and supplies most of the melting energy. Ignoring the topographical effects results in an increase of $37 \%$ in the annual incoming shortwave radiation on the glacier. It causes a decrease in the mass balance of $0.34 \mathrm{~m}$ w.e. Therefore, it is important to take into account topographic effects on shortwave radiation when modelling the mass balance. A $1{ }^{\circ} \mathrm{C}$ increase in the air temperature changes the mass balance of 1999 by $-0.67 \mathrm{~m}$ w.e., while increasing the precipitation by $10 \%$ causes a change of $0.17 \mathrm{~m}$ w.e.

We investigated the modelled climate sensitivity of the mass balance of Morteratschgletscher and its dependence on albedo parameterisation (Chapter 4), as albedo parameterisations are often regarded as a main source of errors in models. For this study we used the same twodimensional mass-balance model. We ran the model for a period of 23 years, from 1980 to 2002, and forced the model with data from synoptic weather stations in the vicinity of Morteratschgletscher. We compared the mass-balance simulations with measurements carried out on Morteratschgletscher and six other glaciers. The first albedo parameterisation used for the simulations relates the snow albedo to snow age and snow depth, whereas it considers the ice albedo to be constant in time and space (0.34). The simulated net mass balance of Morteratschgletscher is somewhat lower than the measurements of six glaciers located up to $123 \mathrm{~km}$ away from Morteratschgletscher. It correlates best with mass-balance measurements of Silvretta ( $R=0.91)$, which is the glacier closest to Morteratschgletscher. We calculated the mass-balance sensitivity by perturbing the air temperature by values ranging from -2 to $+2 \mathrm{~K}$ and precipitation by values ranging from -20 to +20 percent. The mass-balance sensitivity to temperature and precipitation are $-0.59 \mathrm{~m}$ w.e. $\mathrm{a}^{-1} \mathrm{~K}^{-1}$ and $0.17 \mathrm{~m}$ w.e. $\mathrm{a}^{-1}$ per 10 percent respectively.

We then investigated the impact of using three other albedo parameterisations on mass-balance sensitivity. One parameterisation uses ice albedo values that varies in space, acquired from a Landsat image. Another parameterisation calculates the snow albedo from accumulated daily maximum temperatures since snowfall. The fourth parameterisation is the simplest and uses two constant albedo values, one for snow and one for ice. The differences between the mass-balance sensitivities, calculated with the various albedo parametersations, are generally small. However, when the simplest parameterisation is used, the mass-balance sensitivity to temperature decreases to $-0.52 \mathrm{~m}$ w.e. $\mathrm{a}^{-1} \mathrm{~K}^{-1}$. This is mainly due to the constant snow albedo. For an accurate estimate of the mass-balance sensitivity, the albedo parameterisation should capture the process of a decreasing snow albedo when a snow pack gets older or thinner. 


\section{CLIMATIC INTERPRETATION OF GLACIER FLUCTUATIONS}

To extract a climate signal from worldwide glacier length fluctuations, we developed a simple analytical model (Chapter 5). The climate signal extracted from length records is represented as a mass-balance history and as a reconstruction of the equilibrium line altitude (ELA), which is the fictitious line where the specific mass balance is zero. The analytical model takes into account the main characteristics of a glacier, including the response time and the geometry. An advantage of this model over the use of numerical flowline models is that it requires less input information. The simple analytical model is based on the assumption that the change in glacier length can be described by a linear response equation. A parameter sensitivity test shows that uncertainties in the width of the glacier tongue, the melt rate at the glacier terminus and the mass-balance gradient have the largest impact on the ELA reconstruction.

The analytical model was tested on 17 European glacier length records. The results reveal that the ELA of these glaciers increased on average $54 \mathrm{~m}$ between 1920 and 1950. The calculated mass-balance fluctuations are in agreement with mass-balance reconstructions derived from numerical flowline models and from temperature and precipitation records, but are shifted forward in time by a decade. This is due to one of the model assumptions that glacier length immediately starts to respond to a change in the mass balance. The analytical model is not suitable for glaciers with strong variations in the slope or width of the glacier valley and it is only valid for relatively small glacier length fluctuations.

We then derived historic fluctuations of the equilibrium line altitude on the basis of nineteen glacier length records from different parts of the world. The results show that all glaciers in our data set experienced an increase in the ELA between 1900 and 1960. Between 1910 and 1959, the average increase was $33 \mathrm{~m}$. This implies that during the first half of the twentieth century, the climate was warmer or drier than before. The ELAs decreased to lower elevations after 1960 and up till 1980, when most of our ELA reconstructions end. ELA reconstructions also revealed regional differences. Changes in the ELA were most pronounced for North America, Europe and New Zealand, but less pronounced for Asia and South America. The results were translated into a global temperature increase of about $0.8 \mathrm{~K}$ for the period 1910-1959. 


\section{SAMENVATTING}

Kleine gletsjers, en dat zijn alle gletsjers op aarde met uitzondering van de grote ijskappen op Antarctica en Groenland, hebben zich sterk teruggetrokken tijdens de afgelopen eeuw. Kleine gletsjers zijn in vergelijking tot grote ijskappen vaak gevoeliger voor veranderingen in het klimaat, en daarnaast reageren zij sneller op een klimaatverandering. Met andere woorden, kleine gletsjers hebben een grote klimaatgevoeligheid en een kleine responstijd. Om deze redenen dragen zij aanzienlijk bij aan een zeespiegelstijging als het klimaat opwarmt en de gletsjers zich terugtrekken, maar fungeren zij ook goed als klimaatindicator. Informatie over vroegere gletsjerstanden is daarom erg bruikbaar om het klimaatverleden te reconstrueren.

Veranderingen in gletsjerlengte zijn gerelateerd aan klimaatveranderingen via de massabalans van het gletsjeroppervlak. De massabalans is de verandering in massa per oppervlakte- en tijdseenheid. Het is de som van de processen waarbij sneeuw en ijs worden toegevoegd aan de gletsjer, bijvoorbeeld door sneeuwval, en waarbij sneeuw en ijs verdwijnen door onder andere afsmelting en verdamping. De hoeveelheid smeltwater hangt af van de energiebalans van het gletsjeroppervlak. De energiebalans wordt bepaald door alle energiestromen tussen de atmosfeer en het oppervlak, waaronder de inkomende en gereflecteerde zonnestraling, de inkomende en uitgaande langgolvige straling en de voelbare en latente warmtestromen. Het totaal van deze energiestromen wordt gebruikt voor opwarming of afkoeling van de sneeuw- of ijslaag en voor afsmelting. De energiebalans van een gletsjer wordt normaalgesproken gedomineerd door de hoeveelheid zonnestraling die het oppervlak absorbeert. Deze hangt sterk af van de fractie die gereflecteerd wordt door het oppervlak, ook wel albedo genoemd.

Om de wijze waarop gletsjers op klimaatveranderingen reageren beter te kunnen begrijpen, moet de wisselwerking tussen gletsjers en klimaat worden onderzocht. Daarbij moet gebruik gemaakt worden van metingen en van modellen die gebaseerd zijn op fysische wetten. Om klimaatreconstructies af te leiden uit historische veranderingen in lengte van gletsjers zijn echter ook generalisaties nodig.

Het onderzoek dat beschreven is in dit proefschrift heeft betrekking op deze twee aspecten. Bij het eerste aspect, de wisselwerking tussen gletsjers en klimaat, is gekeken naar de ruimtelijke en tijdsafhankelijke verdeling van de gletsjeralbedo aan de hand van satellietdata (Hoofdstuk 2 ), naar de ruimtelijke verdeling van de energiebalans en massabalans van een gletsjer gebruikmakend van een tweedimensionaal massabalansmodel 
(Hoofdstuk 3) en naar de klimaatgevoeligheid van de massabalans in relatie tot de parametrisatie van de albedo (Hoofdstuk 4). Deze onderzoekingen zijn alle uitgevoerd voor de Morteratschgletsjer in Zwitserland, omdat het IMAU (Instituut voor Marien en Atmosferisch onderzoek, Utrecht) sinds 1995 metingen uitvoert op deze gletsjer met automatische weerstations. Het tweede aspect, het afleiden van een klimaatreconstructie uit gletsjerfluctuaties, is bestudeerd aan de hand van de ontwikkeling van een model dat historische massabalansreeksen berekent uit veranderingen in gletsjerlengte (Hoofdstuk 5). Dit model is getest op een set Europese gletsjers en daarna toegepast op wereldwijde gletsjerdata.

\section{WISSELWERKING TUSSEN GLETSJERS EN KLIMAAT}

Om de variatie in de gletsjeralbedo beter te begrijpen, hebben we een reeks satellietbeelden van de Morteratschgletsjer bestudeerd (Hoofdstuk 2). Deze kennis is nodig om de huidige albedoparametrisaties die gebruikt worden in energiebalansmodellen te verbeteren, omdat zij vaak de tijdsafhankelijke en ruimtelijke veranderingen in de gletsjeralbedo niet goed representeren. Wij hebben de albedo afgeleid uit twaalf Landsat-beelden die genomen zijn tijdens dagen in 1999 en 2000. Het berekenen van de albedo van de Morteratschgletsjer uit satellietdata was een ingewikkelde opgave, omdat het accumulatiegebied van de Morteratschgletsjer erg steil en ruig is. Dit beïnvloedt het signaal dat de satelliet meet. We hebben geprobeerd rekening te houden met alle factoren die van invloed zijn op het satellietsignaal, zoals de topografische effecten op diffuus, direct en door de omliggende berghellingen gereflecteerd zonlicht. Omdat sneeuw en ijs anisotrope reflectoren zijn (dat wil zeggen dat zij niet in alle richtingen evenveel straling weerkaatsen), hebben we het satellietsignaal gecorrigeerd voor de anisotrope eigenschap van ijs en sneeuw. Zover wij weten, is dit nog niet eerder gebeurd voor sneeuw- en ijsoppervlakken tegelijk. Deze correctie kan oplopen tot een verandering in de albedo van 0.10 , afhankelijk van de zonshoogte, het type oppervlak en de golflengteband waarin de satelliet meet. We hebben de onzekerheden in de afgeleide oppervlaktealbedo geanalyseerd, en concluderen dat de onzekerheden het grootst zijn voor gebieden met een grote variatie in topografie en met een hoge albedo. Onzekerheden in de albedo voor ruige gebieden, zoals het accumulatiegebied, hangen samen met de nauwkeurigheid van de plaatsbepaling van het satellietbeeld. Dit beïnvloedt de bepaling van de helling en de oriëntatie van elk satellietpixel, en heeft op zijn beurt weer effect op de correctie van het satellietsignaal voor de topografie en de anisotropie. De onzekerheid in de afgeleide albedo die hiermee samenhangt, is geschat op 0.05. Doordat we parametrisaties voor de correctie voor anisotropie hebben toegepast op albedo's die buiten het geldigheidsgebied van die parametrisaties liggen, 
veelal te hoge albedo's, is een onzekerheid in de albedo van 0.05 gecreëerd. Daarom zou het nuttig zijn wanneer parametrisaties voor de correctie van anisotropie ontwikkeld werden die bruikbaar zijn voor een groter bereik van albedo's, maar ook van zonshoogtes en oppervlaktetypes.

We hebben de Landsat-afgeleide albedo's vergeleken met grondmetingen op de gletsjertong. De Landsat-afgeleide albedo's zijn gemiddeld 0.03 hoger dan de grondmetingen. De satelliet-afgeleide albedo's laten zien dat het ijs van de gletsjer gekarakteriseerd kan worden door overlangse banden met een vrijwel constante albedo. Een band in het midden met een albedo van ongeveer 0.3 wordt begrensd door banden met een lagere albedo (0.15). Dit komt door stof en puin die het oppervlak bedekken. We hebben geconcludeerd dat de albedo van het gletsjerijs niet verandert met de hoogte. In de zomer neemt de albedo van het gletsjerijs toe met 0.06. Dit is waarschijnlijk een gevolg van regenwater dat stof en kleine rotsdeeltjes van het gletsjeroppervlak wegspoelt, en blijkt uit een vergelijking tussen gemeten neerslag in de zomer en gemeten albedo op de gletsjertong. Wat betreft de parametrisatie van de albedo in energiebalansmodellen hebben we geconcludeerd dat de ijsalbedo van de Morteratschgletsjer niet als functie van de hoogte zou moeten worden geparametriseerd.

We hebben de ruimtelijke verdeling in de energie- en massabalans van de Morteratschgletsjer bestudeerd aan de hand van een tweedimensionaal massabalansmodel dat gebaseerd is op de energiebalans van een gletsjer (Hoofdstuk 3). Het tweedimensionale model is een verbetering ten opzichte van eerdere modellen, die nul- of eendimensionaal van aard zijn en daardoor de ruimtelijke verdeling niet volledig meenemen. Omdat de Morteratschgletsjer steil is en tussen hoge bergen ligt, hebben we de inkomende zonnestraling gecorrigeerd voor schaduweffecten, helling, oriëntatie, reflectie van de zijwanden en afscherming van een deel van de hemelkoepel. We hebben de effecten van deze topografische correcties op de inkomende straling en de massabalans geanalyseerd. Daarnaast hebben we de gevoeligheid van de massabalans op een verandering in het klimaat onderzocht. We baseerden onze resultaten op modelsimulaties van twee jaar: 1999 en 2000. Meteorologische data van synoptische weerstations in de omgeving van de Morteratschgletsjer dienen als input voor het model in plaats van data van de weerstations die op de Morteratschgletsjer zijn geplaatst. Het verschil tussen deze twee data is dat de instrumenten op de Morteratschgletsjer het microklimaat van de grenslaag boven de gletsjer meten, terwijl de data van de synoptische weerstations het lokale klimaat van een alpien gebied weergeven. Om de verandering in de massabalans als gevolg van een klimaatverandering te kunnen bestuderen, moet de massabalans gegenereerd worden uit data die niet beïnvloed zijn door de gletsjer. We hebben het model gekalibreerd door de turbulente uitwisselingscoëfficiënt, die nodig is om de voelbare en latente warmtestroom te 
berekenen, zo te kiezen dat de hoeveelheid gesimuleerde afsmelting overeenkwam met gemeten afsmelting op de gletsjertong.

De modelresultaten zijn het gevoeligst voor onzekerheden in de waarde van de ijsalbedo, de keuze van de temperatuur waarbij regen overgaat in sneeuw en de bewolkingsgraad. Een toename in de bewolkingsgraad van 0.2 zorgt voor een verandering in de massabalans van de Morteratschgletsjer van $0.18 \mathrm{~m}$ w.e. (water equivalent). De gesimuleerde massabalans is $-0.47 \mathrm{~m}$ w.e. voor het jaar 1999 en $0.23 \mathrm{~m}$ w.e. voor 2000. De energiestromen variëren vooral met de hoogte, maar zonnestraling varieert ook lateraal. Als de topografische effecten op de zonnestraling niet mee zouden worden genomen, dan zou het gletsjeroppervlak $37 \%$ meer zonnestraling ontvangen. Hierdoor zou de gemiddelde massabalans met $0.34 \mathrm{~m}$ w.e. afnemen. Het is dus belangrijk voor het modelleren van de massabalans om de effecten van topografie op zonnestraling mee te nemen. Een temperatuurstijging van $1{ }^{\circ} \mathrm{C}$ zorgt voor een verandering in de massabalans van 1999 van $-0.67 \mathrm{~m}$ w.e., en een toename in de neerslag van $10 \%$ zorgt voor een verandering in de massabalans van $0.17 \mathrm{~m}$ w.e.

Albedoparametrisaties vormen vaak een belangrijke bron van onzekerheden in massabalansmodellen. Daarom onderzochten we de klimaatgevoeligheid van de massabalans van de Morteratschgletsjer in meer detail en hoe zij afhangt van de gebruikte albedoparametrisatie (Hoofdstuk 4). We gebruikten hiervoor wederom het tweedimensionale massabalansmodel en forceerden het model met meteorologische gegevens van synoptische weerstations in de omgeving van de Morteratschgletsjer. We simuleerden de massabalans over een periode van 23 jaar, van 1980 tot 2002 , en vergeleken de modelresultaten met metingen die zijn uitgevoerd op de Morteratschgletsjer en zes andere gletsjers. De eerste albedoparametrisatie die gebruikt werd, relateert de sneeuwalbedo aan de sneeuwdiepte en de ouderdom van de sneeuw, terwijl de ijsalbedo constant is in tijd en ruimte (0.34). De gesimuleerde massabalans is over het algemeen iets lager dan de gemeten massabalans van de zes nabijgelegen gletsjers (tot een afstand van $123 \mathrm{~km}$ ) en correleert het beste met de dichtstbijgelegen gletsjer, Silvretta $(\mathrm{R}=0.91)$. We berekenden de gevoeligheid van de massabalans door de temperatuur te variëren met waarden tussen -2 en $+2 \mathrm{~K}$ en neerslag met waarden tussen -20 tot $+20 \%$. De gevoeligheid van de massabalans is $-0.59 \mathrm{~m}$ w.e. $\mathrm{a}^{-1} \mathrm{~K}^{-1}$ voor een temperatuurverandering en $0.17 \mathrm{~m}$ w.e. $\mathrm{a}^{-1}$ per $10 \%$ voor een verandering in neerslag.

Daarna berekenden we de massabalansgevoeligheid met drie andere albedoparametrisaties. Eén albedoparametrisatie lijkt op de eerdergenoemde parametrisatie, maar gebruikt een ijsalbedo die varieert in de ruimte en is afgeleid uit satellietbeelden. Een andere parametrisatie berekent de sneeuwalbedo als functie van de som van dagelijkse maximumtemperaturen sinds de laatste sneeuwval. De vierde parametrisatie is erg 
eenvoudig: er worden twee constante albedowaarden gebruikt, één voor sneeuw en één voor ijs. De verschillen in de berekende massabalansgevoeligheden zijn over het algemeen klein. Alleen de eenvoudigste parametrisatie zorgt voor een duidelijke afname in de massabalansgevoeligheid voor temperatuur naar een waarde van $-0.52 \mathrm{~m}$ w.e. $\mathrm{a}^{-1} \mathrm{~K}^{-1}$. Dit wordt veroorzaakt door de constante albedo van sneeuw. Daarom moet, om een nauwkeurige klimaatgevoeligheid van de massabalans te kunnen berekenen, een albedoparametrisatie in ieder geval het proces van een afnemende albedo meenemen wanneer de sneeuwlaag dunner en de sneeuw ouder wordt.

\section{KLIMAATRECONSTRUCTIES AFGELEID UIT GLETSJERFLUCTUATIES}

Met als doel een klimaatsignaal af te leiden uit wereldwijde veranderingen in de lengte van gletsjers, hebben we een eenvoudig analytisch model ontwikkeld (Hoofdstuk 5). Het afgeleide klimaatsignaal bestaat uit een reconstructie van de massabalans of de hoogte van de evenwichtslijn. De evenwichtslijn is een fictieve lijn op de gletsjer die punten met een massabalans van nul met elkaar verbindt.

Het analytische model houdt rekening met de belangrijkste eigenschappen van de gletsjer, zoals de responstijd en de geometrie. Een voordeel van het model boven het gebruik van een numeriek stromingsmodel is dat minder inputgegevens nodig zijn. Het eenvoudige analytische model is gebaseerd op de aanname dat de reactie van de gletsjerlengte op een klimaatverandering kan worden beschreven door een lineaire responsvergelijking. Een gevoeligheidstest heeft aangetoond dat onzekerheden in de breedte van de gletsjertong en de hoeveelheid afsmelting op de gletsjertong, alsmede de gradiënt van de massabalans met de hoogte de grootste invloed hebben op de klimaatreconstructie.

We hebben het model getest voor 17 Europese gletsjers. De resultaten geven aan dat tussen 1920 en 1950 de hoogte van de evenwichtslijn gemiddeld met $54 \mathrm{~m}$ is toegenomen. De berekende massabalansreconstructies komen overeen met reconstructies die zijn afgeleid uit numerieke stromingsmodellen of berekend zijn met historische temperatuur- en neerslagreeksen. Echter, de reconstructies berekend met het analytische model zijn ongeveer 10 jaar vooruitgeschoven in tijd. Dit wordt veroorzaakt door één van de modelaannames, namelijk dat de gletsjerlengte direct reageert op een verandering in de massabalans. Het analytische model is niet geschikt voor gletsjers met een sterke variatie in de helling en breedte van het gletsjerdal en is alleen geldig voor relatief kleine gletsjerfluctuaties.

Daarna hebben we het model toegepast om van negentien gletsjers uit verschillende gebieden op aarde de hoogte van de evenwichtslijn te 
reconstrueren. De resultaten geven aan dat tussen 1900 en 1960 alle gletsjers een stijging in de hoogte van de evenwichtslijn ondervonden. Tussen 1910 en 1959 steeg de evenwichtslijn gemiddeld met $33 \mathrm{~m}$. Dit betekent dat de eerste helft van de twintigste eeuw droger of warmer was dan daarvoor. De hoogte van de evenwichtslijn daalde vanaf 1960 tot aan 1980, wanneer de meeste reconstructies eindigen. De reconstructies laten ook regionale verschillen zien. Veranderingen in de hoogte van de evenwichtslijn waren sterker in Noord Amerika, Europa en Nieuw-Zeeland dan in Zuid-Amerika en Azië. De resultaten kunnen vertaald worden in een globale opwarming van ongeveer $0.8 \mathrm{~K}$ tijdens de periode 1910-1959, wanneer we aannemen dat de hoeveelheid neerslag niet veranderd is over deze periode. 


\section{$1^{\text {NNTroouctron }}$}

\subsection{GLACIERS AND CLIMATE}

Glaciers form where the snow that falls each year does not entirely melt, and thus accumulates. When this occurs over an extended period of time, the remaining snow gradually transforms into ice and forms a glacier. The final glacier extent and geometry depend on the land topography and the physical properties of ice, as well as on the climate.

Glacier ice covers 10 per cent of the earth's land surface, but during the ice ages this was three times as much (Paterson, 1994). All but one per cent of the present ice is stored in two great ice sheets on Greenland and Antarctica. The total glacier area outside these two ice sheets is estimated at $680000 \mathrm{~km}^{2}$ (Dyurgerov, 2002). This area consists of ice caps, ice fields, valley and mountain glaciers, which are also described as small glaciers. Figure 1.1 shows where the world's small glaciers are located.

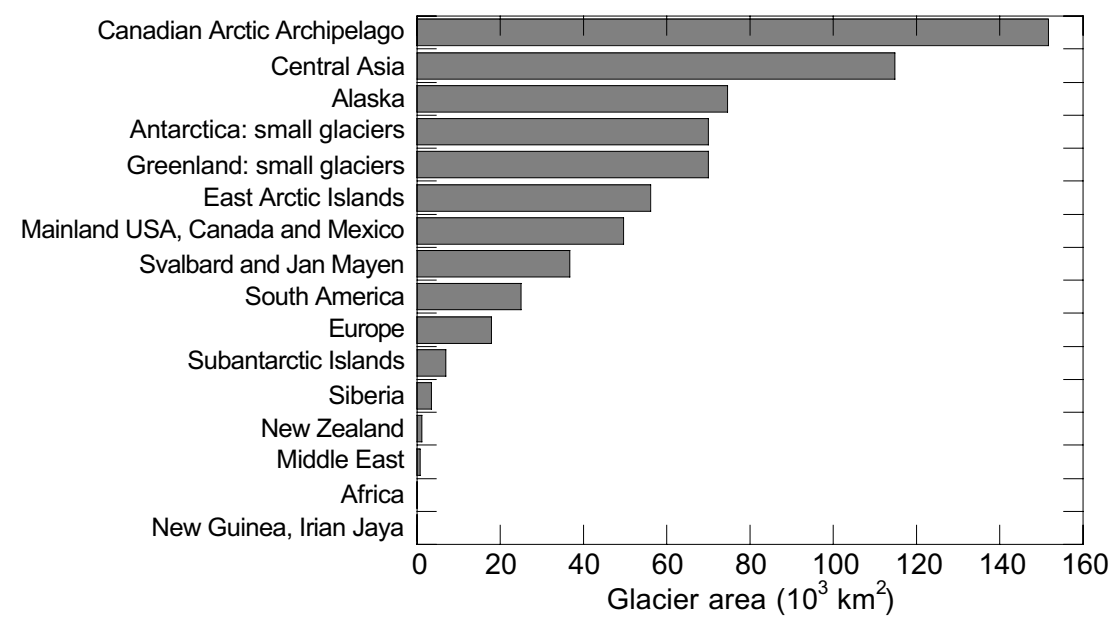

Figure 1.1: Surface area of small glaciers from data compiled by Dyurgerov (2002).

Although the total ice volume stored in small glaciers is small compared to the volume of the great ice sheets, they are of great concern in the context of climate change. Small glaciers are more sensitive to changes in climate than the ice sheets on Greenland and Antarctica because they are mostly located in warmer and wetter areas (Oerlemans and Fortuin, 1992). Because the temperature in these regions is more often close to freezing point, a temperature rise will not only result in an increase in melt, but also in the occurrence of rain, which implies less snow accumulation. In 
addition, small glaciers reflect changes in climate with a much shorter delay than the great ice sheets. In other words, small glaciers have a shorter response time.

During the $20^{\text {th }}$ century, global surface air temperature increased by $0.6{ }^{\circ} \mathrm{C}$ (IPCC, 2001) and many small glaciers retreated. Observations and models indicate that the loss of ice due to this glacier retreat contributed 0.2 to $0.4 \mathrm{~mm}$ per year to sea-level rise between 1910 and 1990. This is large compared to the estimated contributions from the great ice sheets: 0.0 to 0.1 $\mathrm{mm}$ per year for Greenland and -0.2 to $0.0 \mathrm{~mm}$ per year for Antarctica. The estimated total rate of observed global sea level rise during the 20th century ranges between 1.0 and $2.0 \mathrm{~mm}$ per year. Other processes that explain this sea level rise are thermal expansion of the ocean and changes in permafrost and the terrestrial storage of surface and ground water.

Because small glaciers are sensitive to changes in climate and have short response times, they serve as good climate indicators. Information on the limits of small glaciers at different times in the past can be used to make inferences about the historical climate. This type of information complements meteorological records, as glacier length records generally extend further back in time, and are often from remote areas and higher altitudes, for which meteorological data are scarce (IPCC, 2001).

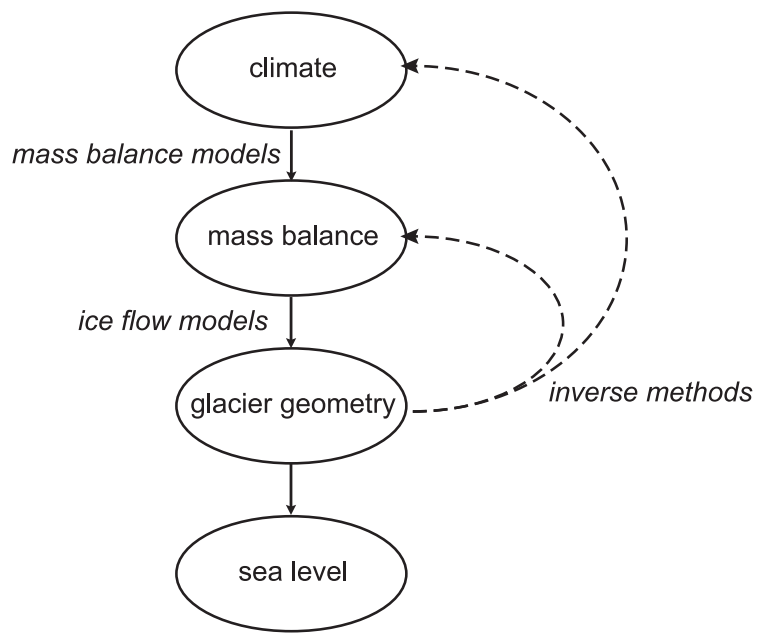

Figure 1.2: Schematic visualisation of the climate-glacier system.

Inferring climate information from glacier fluctuations can be regarded as inverse modelling. This is clarified in Figure 1.2, which shows a flow diagram of the interaction between climate and glaciers. Climate forces the mass balance of glaciers, which is the sum of all processes by which snow and ice are added to the glacier, e.g. in the form of snowfall, or removed from it, for example by melting and evaporation. The interactions between climate and the mass balance can be investigated using mass- 
balance models. A positive or negative mass balance will lead to an advance or retreat of the glacier respectively. Ice flow models simulate the dynamical response of the glacier geometry to a change in the mass balance. A change in the total volume of many glaciers will finally be reflected by a change in sea level.

Small glaciers are not merely interesting study objects for their contribution to sea level change or for interpretation of the past climate. Their melt water is also important for water supply, irrigation systems and hydroelectric power schemes in many countries. For these reasons, research should be conducted on the relationships between climate and small glaciers and on how they respond to a climate change.

This thesis addresses two issues for small glaciers: the physical processes that govern the interaction between the climate and the glacier mass balance (Chapters 2 to 4 ), and the climatic interpretation of glacier length fluctuations using an inverse method (Chapter 5). The first issue is concerned with the spatial and temporal variation in glacier albedo, and the spatial variation of the mass balance as studied from a mass-balance model. It also deals with the sensitivity of the mass balance to changes in climate. This section focuses on Morteratschgletscher in Switzerland. The second issue includes the development of a method that derives mass-balance records from glacier length fluctuations. This method allows for reconstruction of the historical climate from a global dataset of glacier length fluctuations.

In the next section, I explain some of the basic concepts and terminology related to these research subjects. Section 1.3 describes the contents of this thesis in more detail.

\subsection{BACKGROUND}

\subsubsection{GLACIER MASS BALANCE}

The net mass balance of a glacier is the change in mass per unit area over a period of time. It is the sum of accumulation and ablation.

Accumulation includes all processes which add snow and ice to the glacier, such as snowfall, avalanches, rime and freezing of rain, and ablation includes all processes by which snow and ice are lost from the glacier: melting, run off, evaporation, snowdrift, and calving (Paterson, 1994). The mass balance is often expressed in metres water equivalent per year ( $m$ w.e. $\mathrm{a}^{-1}$ ), and is normally measured over a balance year, which starts and ends at the end of the ablation season. The specific mass balance refers to the net mass balance at a certain location on the glacier. Specific balance rate, mean specific mass balance, surface mass balance, annual mass balance or simply mass balance are also terms used in literature and in this thesis that indicate 
how much mass is gained or lost per unit area over a certain period. From the text, it is normally clear which area and time period are meant. When the total amount of accumulation on a glacier equals the total amount of ablation over a period of many years, the glacier is in equilibrium with the climate. This is called a steady-state glacier.
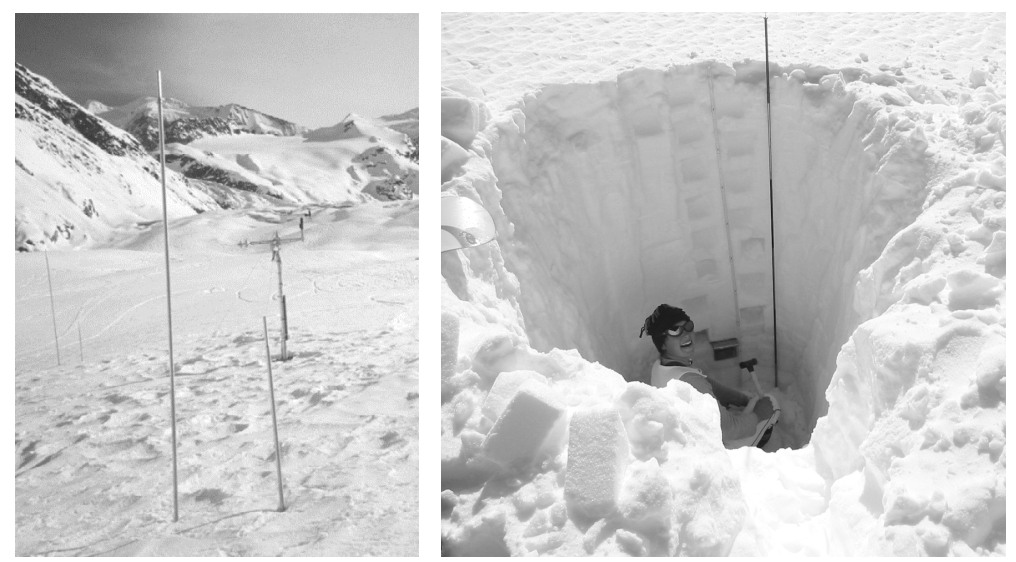

Figure 1.3: Left: Two stakes drilled into the glacier and in the background an automatic weather station. Right: Measuring snow density in a snow pit.

There are several methods of measuring the mass balance of a glacier, for instance the geodetic method and the glaciological method. The first method estimates the volume change between two different times from the change in surface elevation derived from topographic maps or remote sensing techniques. The latter estimates the change in mass from stakes, which are drilled into the glacier at several locations, and from snow density measurements (Figure 1.3).

Figure 1.4 shows the measured specific mass balance as function of elevation averaged over several years for five glaciers. The accumulation area of the glacier is the area where the net specific mass balance is positive and the ablation area is where the net specific mass balance is negative. These two areas are separated by an imaginary line where the balance is zero: the equilibrium line. Compared to the other glaciers, the equilibrium line altitude (ELA) of Nigardsbreen is very low and its specific mass balance at the glacier tongue also reaches very low values $\left(-10 \mathrm{~m}\right.$ w.e. $\left.\mathrm{a}^{-1}\right)$. This is due to its maritime climate, which implies much snowfall in winter and high melt rates in summer. The average ELA of the glaciers in the European Alps is $2900 \mathrm{~m}$ a.s.l., reflecting the continental climate. This can also be seen in differences in the mass-balance gradients (Munro, 1991), which is the dependence of the mass balance on altitude. The mass-balance gradient of the ablation area is largest for South Cascade: $0.023 \mathrm{~m}$ w.e. $\mathrm{a}^{-1}$ $\mathrm{m}^{-1}$. This large gradient indicates that the glacier is located in a maritime 
climate and that the mass turnover is large. The lowest mass-balance gradient shown in the figure is for Griesgletscher: $0.007 \mathrm{~m}$ w.e. $\mathrm{a}^{-1} \mathrm{~m}^{-1}$, which is typical of glaciers in the European Alps (Oerlemans, 2001).

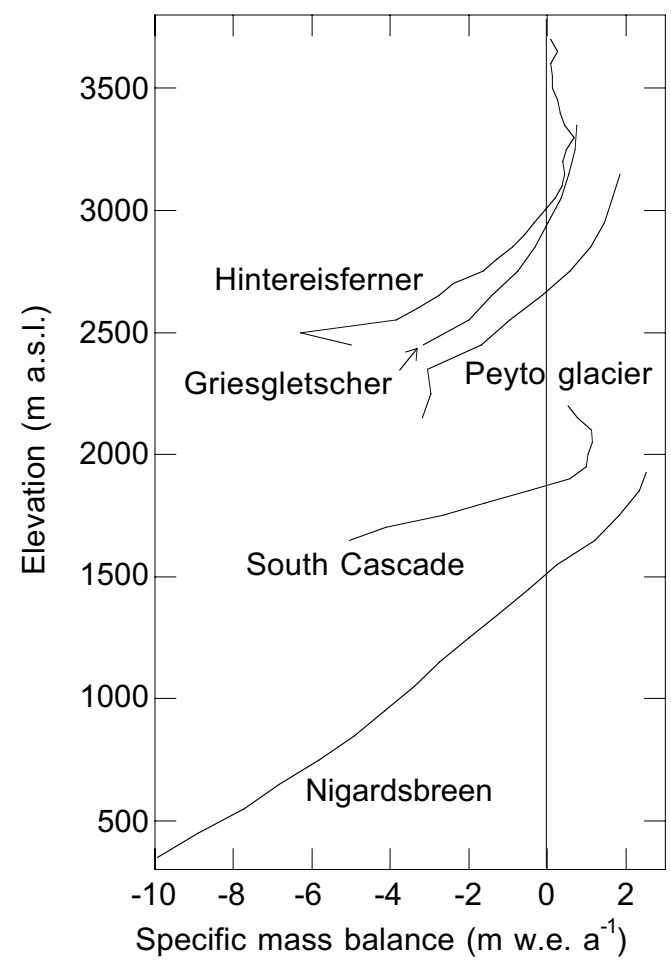

Figure 1.4: Measured net specific mass balance as function of elevation, averaged over several years for Hintereisferner (Austria), Griesgletscher (Switzerland), Peyto glacier (Canada), South Cascade (U.S.A.) and Nigardsbreen (Norway). The accumulation area of the glacier is the area where the specific mass balance is positive and the ablation area is where the specific mass balance is negative. The equilibrium line is located at the altitude where the balance is zero.

The net mass balance of a glacier can be calculated from the specific mass balance shown in Figure 1.4 using an area-weighted integration. In the literature, the accumulated net mass balance of a glacier is often plotted (see Figure 1.5). Since 1962, Nigardsbreen has gained mass, while the other glaciers have all lost mass. Although it is tempting to suppose that this figure reflects the regional climate variability, the depicted lines are also influenced by different climate sensitivities of the glaciers due to differences in hypsometry (Kuhn et al., 1985) and climate. Glaciers located in maritime climates are often more sensitive to changes in air temperature than continental glaciers (Oerlemans and Fortuin, 1992) and will therefore show larger fluctuations in the mass balance for a given change in temperature. 
And glaciers with a large accumulation area will benefit more from an increase in snowfall than glaciers with a small accumulation area, reflected in a larger net mass balance. Another important point to consider is that a changing glacier geometry also influences the mass balance of a glacier. For instance, a temperature increase will result in a more negative net mass balance for a retreating glacier that is recovering from an earlier change in climate, than for a steady-state glacier. Therefore, one should be careful in linking the (accumulated) net mass balance to instantaneous changes in climate (Oerlemans, 2001).

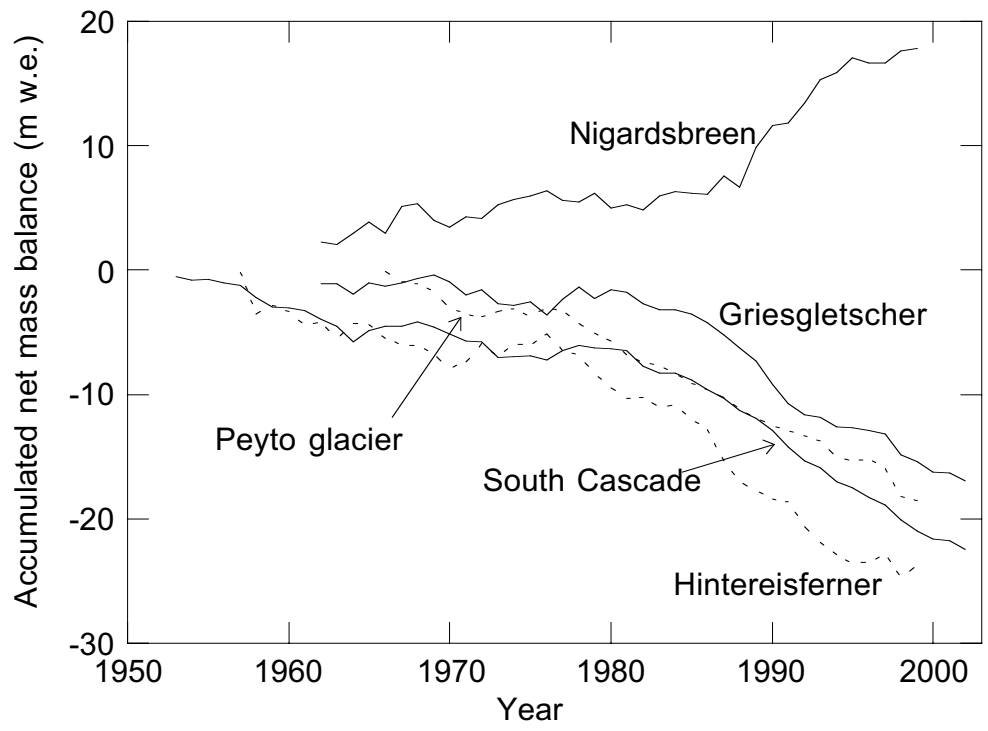

Figure 1.5: Accumulated net mass balance of five glaciers (see Figure 1.4).

\subsubsection{MASS-BALANCE MODELS}

Among the simplest models that relate the mass balance or melt rate to climate are degree-day models (e.g. Braithwaite, 1995). These regression models use correlations between the melt rate and mean summer air temperature, or positive degree-days, to estimate the annual ablation. Although these models perform very well in simulating the melt rate, they do not give insight into the physical processes of glacier melt. Besides, it is questionable whether the coefficients of the degree-day models also hold for a different climate, as they are often calibrated for the present climate. Climate experiments carried out with degree-day models should therefore be interpreted with care.

A more sophisticated approach is to calculate glacier melt from the surface energy-balance of a glacier. This considers the physical processes 
governing the melt. The energy balance of a glacier surface can be written as:

$$
S_{\text {in }}-S_{\text {out }}+L_{\text {in }}-L_{\text {out }}+Q_{H}+Q_{L}+Q_{R}=Q_{m}+G
$$

$S_{\text {in }}$ and $S_{\text {out }}$ are incoming and reflected solar radiation, $L_{\text {in }}$ and $L_{\text {out }}$ are incoming and outgoing longwave radiation, and $Q_{H}$ and $Q_{L}$ are respectively the sensible and the latent heat flux, together called the turbulent fluxes. The turbulent fluxes are positive when directed towards the surface. $Q_{R}$ is the heat flux supplied by rain, which in most cases is very small. These fluxes determine the total energy flux between the atmosphere and the glacier surface (Figure 1.6). $G$ is the loss or gain of heat of the snow or ice pack and $Q_{m}$ is the heat used to melt snow and ice. Melt water that penetrates into the glacier may refreeze, in which case it does not contribute to a change in the mass balance. Melt water that refreezes raises the temperature of the glacier, by the release of latent heat.

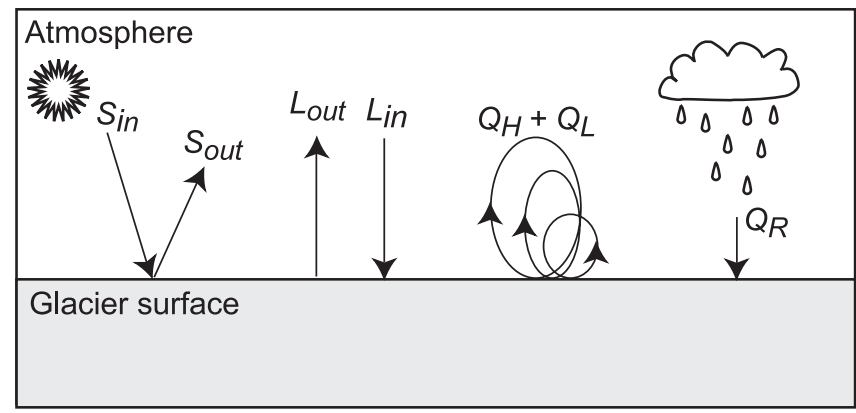

Figure 1.6: Surface energy fluxes between glacier surface and atmosphere. Symbols are explained in the text.

The amount of solar radiation received by the glacier's surface depends on the solar zenith angle, the state of the atmosphere and the surface topography. During its path through the atmosphere, a part of the solar radiation is scattered back or absorbed by clouds, gases, molecules and aerosols. For mountainous areas, topographical effects such as the orientation of the surface, shading, reflection of radiation from surrounding slopes and obstruction of the sky play an important role in the amount of solar radiation that reaches the glacier surface (Greuell et al., 1997). This is one of the topics that are investigated in Chapter 3.

The surface albedo is the fraction of the incoming solar radiation that is reflected at the glacier surface (Section 1.2.4). It varies widely between fresh snow and dirty ice, from 0.97 to 0.10 (Paterson, 1994). A small amount of radiation also penetrates into the snow pack, and contributes to the warming of the snow or ice $(G)$ or causes melting. Generally, net shortwave 
radiation is the main contributor to the energy available for melting. Therefore, accurate estimations of the incoming solar radiation and the surface albedo are important for determining the melt rate.

Incoming longwave radiation is the amount of infra-red radiation emitted by the atmosphere. Snow and ice act as a black bodies in the infrared and thus absorb virtually all of the received longwave radiation, but also emit longwave radiation according to their temperature.

The sensible and latent heat fluxes are the transport of respectively heat and water vapour between the atmosphere and the glacier surface. For a melting glacier, the air immediately above the surface is normally warmer than the ice. Eddies then conduct heat to the surface, and depending on the water vapour pressure gradient, the surface gains heat when vapour condenses onto it or loses heat when water vapour evaporates from the surface.

All of the fluxes mentioned above need to be modelled or measured to determine the mass balance. Oerlemans (2000) analysed the mass balance from the surface energy balance for one point on Morteratschgletscher, using measurements from an automatic weather station located on the glacier. Modelling the mass balance at several points along the centre line of a glacier can be regarded as one-dimensional (e.g. Munro, 1991). To estimate the mass balance of the entire glacier, the melt rate and accumulation of every single point on the glacier should be determined. Spatiallydistributed or two-dimensional models are used for this purpose. The model that we used to study the spatial distribution of the mass balance and its sensitivity to a change in climate (Chapters 3 and 4), is a twodimensional model based on the surface energy balance of a glacier.

Using mass-balance models, the mass-balance sensitivity with regard to a change in climate can be determined. This is the response of the mass balance to a perturbation in temperature, precipitation or for instance cloudiness. The mass-balance sensitivity depends on several factors, such as the climate in which the glacier is located and the glacier geometry (accumulation area, ablation area, and slope). The slope of the glacier is important for the mass balance - surface elevation feedback. This positive feedback enhances a change of the mass balance by the response of the surface elevation. For instance, a temperature decrease will result in less melt and more snowfall and hence in an increase in surface elevation. With increasing height, the temperature decreases, which in turn causes less melt and more snowfall. For gentle slopes, this feedback is stronger, as glaciers can grow thicker on gentle slopes than on steep slopes (Oerlemans, 2001).

\subsubsection{Albedo}

Variations in the surface albedo explain differences in the glacier melt rate to a large extent (Van de Wal et al., 1992) because net shortwave radiation 
is often the largest energy source for the melting process. Small changes in the surface albedo can have a large impact on the melt rate (e.g. Oerlemans and Hoogendoorn, 1989; Munro, 1991). In addition, the variability in the surface albedo of a glacier can be very large as dry fresh snow reflects up to $97 \%$ of the incoming solar radiation, melting snow between 66 and $88 \%$ and ice only 10 to 51\% (Paterson, 1994). Differences in the surface albedo mainly depend on grain size, impurity content, cloudiness, water content, solar inclination and surface roughness (Warren, 1982).

The glacier albedo also influences the climate sensitivity of the mass balance by means of the albedo feedback. This positive feedback results from the fact that a warmer climate leads to larger melt rates, which in turn cause a faster disappearance of the snow pack and a longer period of bare ice. Since ice is less reflective than snow, the glacier will absorb more solar radiation, which in turn leads to more melt. Greuell and Böhm (1998) estimated that due to the albedo feedback, the mass-balance sensitivity of a glacier to a change in temperature of $1 \mathrm{~K}$ increased by $91 \%$.

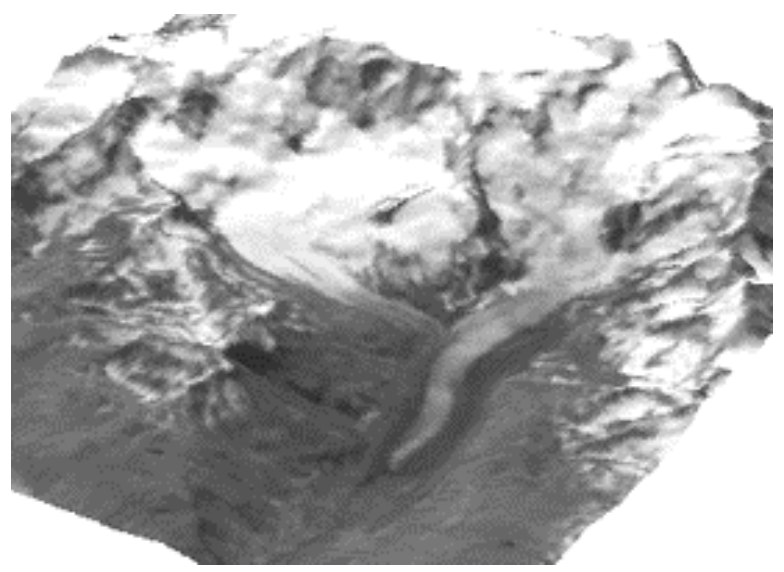

Figure 1.7: Landsat-5 TM image (Band 4) of Morteratschgletscher from 24 June 1999, projected on a digital elevation model.

For these reasons, many studies have investigated the temporal and spatial variations in albedo over a glacier surface and have aimed to develop parameterisations to estimate the albedo when measurements are not available. Most albedo models separate ice and snow albedo. The ice albedo is often taken to be constant, while the snow albedo is a function of snow age, snow depth or accumulated melt (e.g. Oerlemans and Knap, 1998; Brock et al. 2000). Chapter 4 of this thesis investigates the effect of four different albedo parameterisations on the mass balance of Morteratschgletscher and its sensitivity to climate change.

Besides ground-based measurements, satellite images are also used to study the spatial patterns of the glacier albedo (e.g. Koelemeijer et al., 1993; 
Knap et al., 1999). Chapter 2 uses a series of satellite images of Morteratschgletscher to investigate both the spatial and temporal variation of the albedo of Morteratschgletscher.

Satellite sensors that are often used for albedo retrieval are Landsat 5 TM, Landsat 7 ETM+ and NOAA AVHRR. Figure 1.7 shows an example of the reflection of Morteratschgletscher measured by Landsat TM in wavelength band 4 , which is near-infrared. The image (30 m resolution) is projected on a digital elevation model. The snow and ice areas of the glacier are clearly visible.

\subsubsection{AUTOMATIC WEATHER STATIONS}

Automatic weather stations (AWS) are set up on glaciers to measure surface melt, snowfall and the energy balance components. Often, an AWS measures for a short period in the ablation season, but useful data sets cover an entire year or even a period of several years. The Institute for Marine and Atmospheric research, Utrecht, (IMAU) operates AWS on several glaciers including Morteratschgletscher. As Chapters 2 to 4 of this thesis make use of data from the AWS on Morteratschgletscher, I will explain this AWS in more detail.
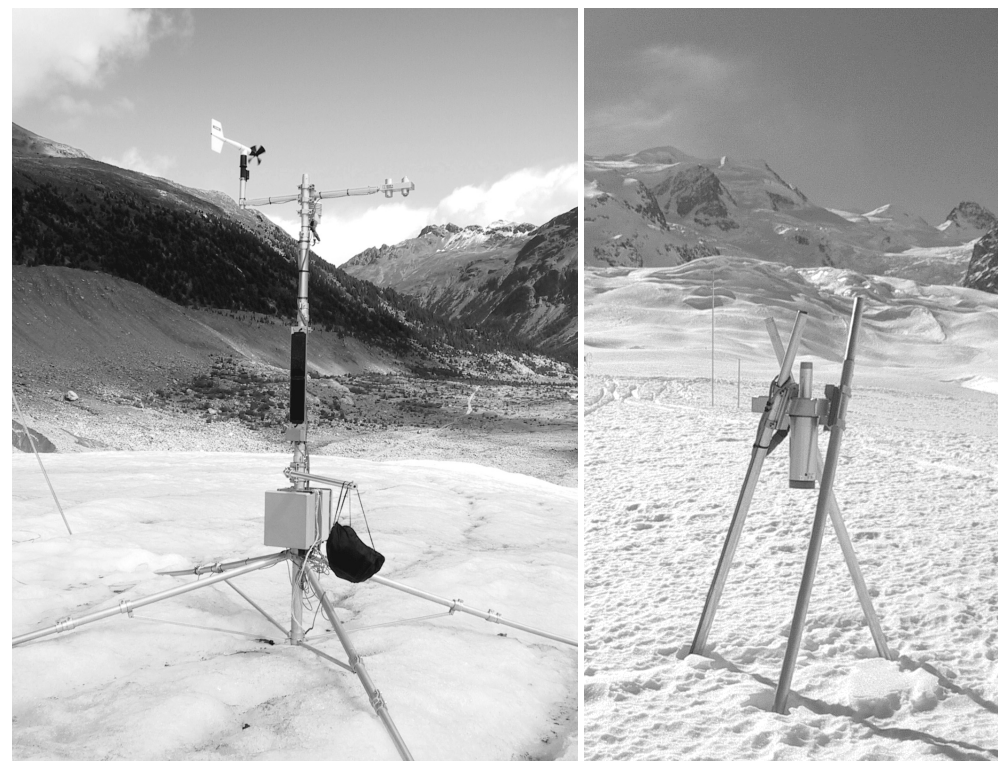

Figure 1.8: Left: automatic weather station on the tongue of Morteratschgletscher. Right: sonic height ranger, about $40 \mathrm{~cm}$ above the glacier surface.

The AWS (Figure 1.8) is designed to operate with infrequent servicing. The mast of the AWS, carrying the instruments, is placed on a four-legged frame. It stands freely on the ice surface and sinks with the melting surface. 
Lithium batteries and a small solar panel provide the energy for the data logger (Campbell CR-10X) and the instruments. The instruments are mounted on a horizontal bar approximately $3.5 \mathrm{~m}$ above the surface and measure incoming and reflected solar radiation and incoming and outgoing longwave radiation (Kipp \& Zonen CNR1), air temperature and humidity (Vaisala HMP35AC, ventilated), air pressure (Campbell PTA), wind speed and wind direction (Young 05103). In winter, the foot of the mast is buried with snow (see Figure 1.3), and the height of the instruments above the surface is diminished by the snow depth. Next to the AWS, a sonic ranger (Campbell SR-50) mounted on a tripod (Figure 1.8) measures the distance to the surface, providing information about surface melt and snow depth. Sampling is done every minute, from which half-hourly averages are calculated and stored. In addition, stakes are drilled into the ice to measure surface melt and in winter, and snow density measurements are made when the site is visited.

The AWS on Morteratschgletscher has been measuring since 1995. Data have been used to study the solar radiation and albedo (Oerlemans and Knap, 1998), and the energy and mass balance (Oerlemans, 2000; Oerlemans and Klok, 2002).

\subsubsection{GLACIER LENGTH FLUCTUATIONS}

Glacier ice flows, and in this way the net mass loss at the glacier surface of the ablation area is compensated by the net mass gain of the accumulation area. Three types of motion contribute to glacier flow: deformation of the ice, sliding of ice over its bed and deformation of the bed itself (Paterson, 1994). Deformation of the ice depends on the shear stress and the characteristics of ice such as temperature, crystal size and orientation, and water and impurity content. Sliding of ice occurs when the basal ice is at melting point. It depends on the amount of water at the glacier bed, the shear stress and the characteristics of the glacier bed. Some glaciers move over a hard bed, which is rigid and impermeable, while other glaciers have a soft bed, which consists of glacial deposits, also called till. Deformation of the bed occurs when this subglacial till is water-saturated and this may then contribute to glacial motion.

Changes in the mass balance lead to changes in the flow of the glacier, and hence to changes in the area and length of the glacier. Figure 1.9 shows the length fluctuations of five glaciers. They all show retreat from 1850 onwards, but Nigardsbreen also advanced after 1990 due to a positive mass balance (see Figure 1.5).

The response of the glacier length to a change in the mass balance or climate is determined by the climate sensitivity and the length response time of the glacier. The climate sensitivity is generally formulated as the change in steady-state length resulting from an external forcing in climate. 
It mainly depends on the geometry of the glacier. Glaciers with a narrow tongue will react to a change in climate with a larger change in length than wide glaciers. And as discussed already, glaciers on a gentle slope are also more sensitive (Section 1.2.2).

The length response time expresses the speed of the glacier response to a change in mass balance. It is defined as the time the glacier needs to attain to a new glacier length of the size $L_{2}-\mathrm{e}^{-1}\left(L_{2}-L_{1}\right)$ due to a change in climate. Here, $L_{1}$ and $L_{2}$ are the steady-state glacier length in respectively the old and new climatic setting (Oerlemans, 2001). Like the climate sensitivity, the response time depends on the geometry of the glacier. Large glaciers and glaciers with a narrow tongue will normally have longer response times. Glaciers on steep slopes will have shorter response times due to the small effect of the mass balance - surface elevation feedback. Besides, glaciers with a large mass-balance gradient will have shorter response times due to a large mass turnover (Oerlemans, 2001).

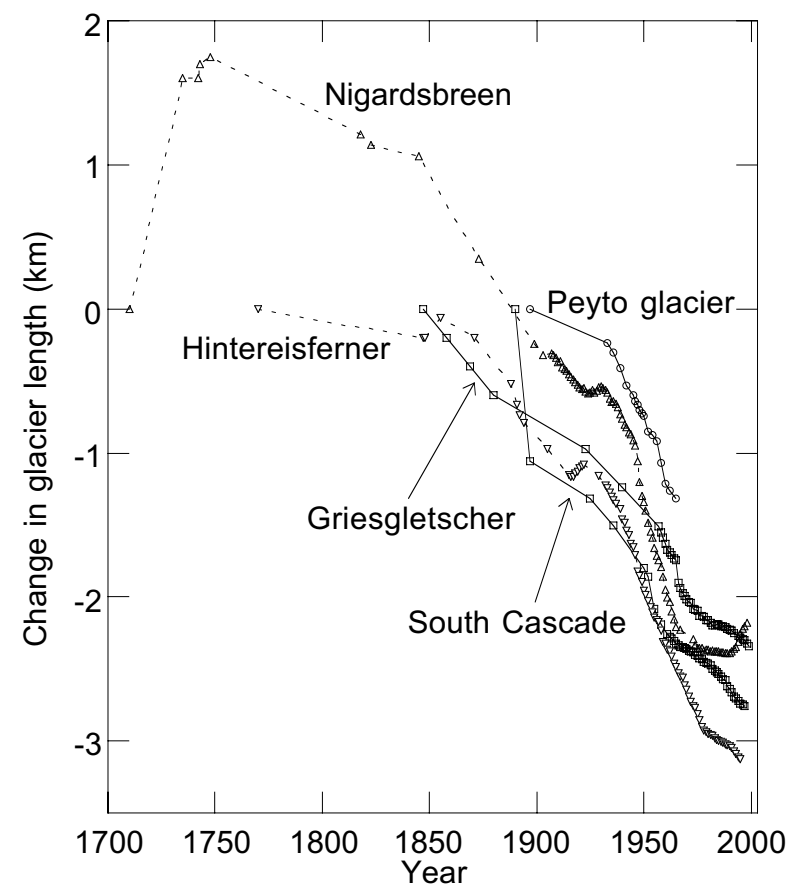

Figure 1.9: Changes in glacier length of five glaciers (see Figure 1.4).

Flow models can be used to calculate historical front fluctuations when forced by a mass-balance history (e.g. Oerlemans, 1986). They can also be used to investigate the glacier's response to climatic warming, when for instance a mass-balance model is coupled to a flow model (e.g. Wallinga and Van de Wal, 1998) or to a climate scenario derived from a global climate model (Schneeberger et al., 2001). Oerlemans et al. (1998) studied the response of 
12 glaciers from dynamic glacier models for a warming rate of $0.01{ }^{\circ} \mathrm{C} \mathrm{a}^{-1}$ and an increase in precipitation of $10 \%{ }^{\circ} \mathrm{C}^{-1}$. The results showed that by the year 2100 , this would cause a loss of 10 to $20 \%$ of the 1990 glacier volume.

\subsubsection{INVERSE MODELLING}

Data on glacier fluctuations from moraines, old pictures and glacier surveys, as depicted in Figure 1.9, can be used for climatic reconstruction. Oerlemans (1997) proposed a procedure to reconstruct historical massbalance records from glacier length data using a numerical flowline model. The advantage of using a flowline model for climatic interpretation of glacier length fluctuations is that the geometric effects on the sensitivity and the response time are taken into account. A disadvantage is that detailed information about the glacier and the bedrock topography is needed, which is not always available. Therefore, dynamic calibration cannot be applied to the large data set of glacier length fluctuations.

For that purpose simpler methods are needed, for instance the method of Oerlemans (1994). He calculated an estimate of global warming during the last century from a set of 48 glacier length records and used a method that needs little input data, but still allows for differences in glacier geometry and climate sensitivity. He found that a linear warming trend of $0.66{ }^{\circ} \mathrm{C}$ per century can explain the observed glacier retreat. Haeberli and Hoelzle (1995) also developed a simple parameterisation scheme, build on four geometric parameters (glacier length and area, minimum and maximum elevation). They reconstructed changes in the mass balance from length fluctuations of glaciers in the European Alps. Unfortunately, neither method accounts for the length response time of the glacier. Chapter 5 of this thesis presents a method that derives a mass-balance reconstruction from glacier length fluctuations while taking into account the response time and the main characteristics of the glacier.

\subsection{CONTENTS OF THIS THESIS}

As discussed in the previous sections, physical processes that govern the interaction between climate and glaciers need to be studied, making use of measurements and physically based models, to understand the response of glaciers to climate change. On the other hand, generalised parameterisations are necessary to translate historic length fluctuations of glaciers into information on the past climate. The research described in this thesis addresses these two topics. The first topic (Chapters 2 to 4 ) is treated by studying the spatial and temporal variation of the glacier albedo from satellite images, by investigating the spatial distribution of the mass-balance and the surface energy-balance fluxes from a two-dimensional mass- 
balance model, and by investigating the sensitivity of the mass balance to changes in climate. All of these studies were focused on

Morteratschgletscher (Figure 1.10). The second topic, climatic reconstruction from glacier length fluctuations, was dealt with by developing a method that derives mass-balance reconstructions from a global data set of glacier length records. The chapters are based on five published, accepted or submitted articles. Chapters 2 to 4 present the articles in almost their exact form, whereas Chapter 5 combines two articles.

Albedo parameterisations used in energy and mass-balance models are often inadequate to represent the changes in the surface albedo in space and time and are consequently regarded as a main source of errors (e.g. Arnold et al., 1996). Therefore, Chapter 2 studies a series of Landsat 5 and Landsat 7 images of Morteratschgletscher over a period of two years to improve the albedo parameterisations used in energy-balance models. The retrieval of the surface albedo of Morteratschgletscher from Landsat images constitutes a tough test for the method, as this glacier has a very steep and rugged accumulation zone. We aimed to retrieve surface albedos while taking into account all important processes that influence the relationship between the satellite signal and the surface albedo.

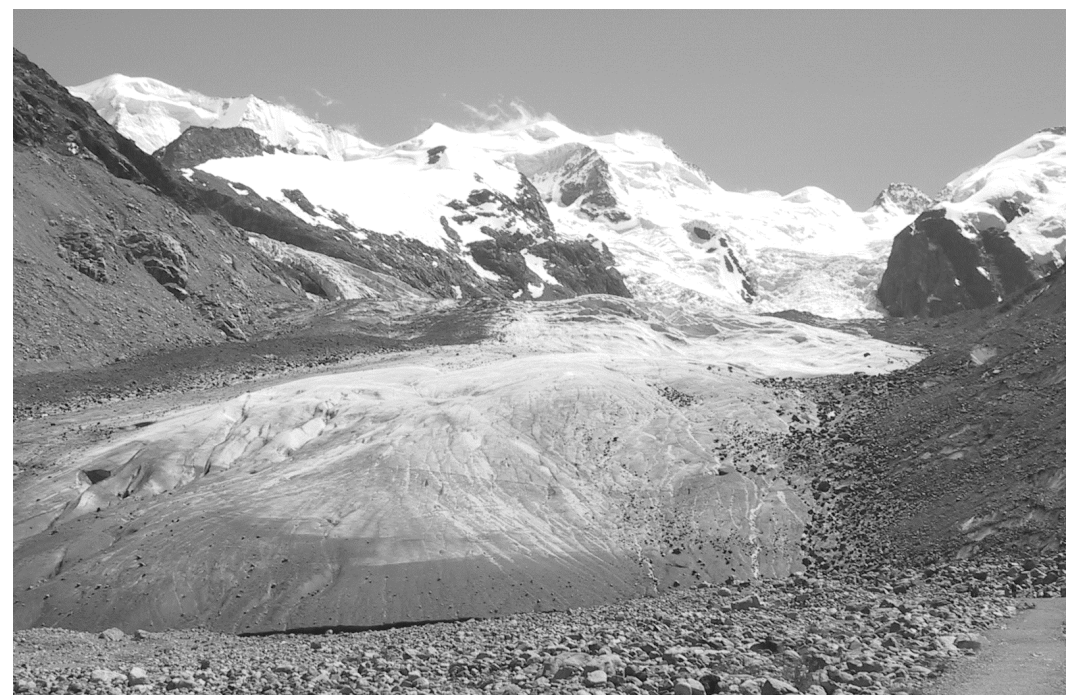

Figure 1.10: Morteratschgletscher in southern Switzerland $\left(46^{\circ} 24^{\prime} \mathrm{N} 8^{\circ} 02^{\prime} \mathrm{E}\right)$. Its altitude ranges from 2000 to $4000 \mathrm{~m}$ a.s.l. The glacier area is $17 \mathrm{~km}^{2}$ and its length is about $7 \mathrm{~km}$.

Chapter 3 addresses the spatial distribution of the energy and massbalance fluxes of Morteratschgletscher, studied using a two-dimensional mass-balance model that is based on the surface energy balance. This model is an improvement over earlier mass-balance models, which are either zero- 
or one-dimensional, because it accounts for the full spatial variation in the energy and mass-balance fluxes. The model is used to investigate the topographical effects on the incoming solar radiation and the net mass balance, based on simulations over a two year period. The topographical effects include shading, surface orientation, reflection from the surrounding slopes and obstruction of the sky. A further aim of this work is to determine the sensitivity of the mass balance of Morteratschgletscher to a climate change.

Because albedo parameterisations are often regarded as the main source of errors in models and the mass balance is very sensitive to small changes in the albedo, Chapter 4 investigates the effect of four different albedo parameterisations on the mass-balance sensitivity of Morteratschgletscher to a change in climate. For this purpose, we used the twodimensional mass-balance model. We ran the model for a period of 23 years: from 1980 to 2002, and estimated the mass-balance sensitivity with regard to changes in air temperature and precipitation. The albedo parameterisations range from a simple model that uses one constant value for snow and another for ice, to more sophisticated parameterisations where the snow albedo depends on snow depth and age and the ice albedo is retrieved from satellite images.

Chapter 5 focuses on the climatic interpretation of worldwide glacier length changes. For this purpose, we developed a simple analytical model that derives the mass-balance history and the ELA of a glacier from its length fluctuations. The model takes into account the main characteristics of a glacier, including the response time and the geometry, as well as the mass balance-surface height feedback. We investigated the effects of the uncertainties in the input data on the ELA reconstruction. The model was tested on 17 European glacier length records that go back to before 1900. We then applied the method to length fluctuations of valley and outlet glaciers from other parts of the world. The results of the ELA and mass-balance reconstructions of the global glaciers are also interpreted in terms of changes in air temperature.

\section{REFERENCES}

Arnold, N.S.I., Willis, I.C., Sharp, M.J., Richards, K.S. and Lawson, W.J. 1996. A distributed surface energy-balance model for a small valley glacier, I, Development and testing for Haut Glacier d'Arolla, Valais, Switzerland. Journal of Glaciology, 42(140), 77-89.

Braithwaite, R.J. 1995. Positive degree-day factors for ablation on the Greenland ice sheet studied by energy-balance modelling. Journal of Glaciology, 41(137), 153-160. 
Brock, B.W., Willis, I.C. and Sharp, M.J. 2000. Measurements and parameterisation of albedo variations at Haut Glacier d'Arolla, Switzerland. Journal of Glaciology, 46(155), 675-688.

Dyurgerov, M.B. 2002. Glacier mass balance and regime: data of measurements and analysis. In: Meier, M. F. and Armstrong, R. (Eds.), Occasional Paper, Vol. 55. Institute of Arctic and Alpine Research, University of Colorado, Boulder, CO: $88 \mathrm{pp}$.

Greuell, W., Knap, W.H. and Smeets, P.C. 1997. Elevational changes in meteorological variables along a midlatitude glacier during summer. Journal of Geophysical Research, 102(D22), 25,941-25,954.

Greuell, W. and Böhm, R. 1998. 2 m temperatures along melting mid-latitude glaciers, and implications for the sensitivity of the mass balance to variations in temperature. Journal of Glaciology, 44(146), 9-20.

Haeberli, W. and Hoelzle., M. 1995. Application of inventory data for estimating characteristics of and regional climate-change effects on mountain glaciers: a pilot study with the European Alps. Annals of Glaciology, 21, 206-212.

IPCC, 2001. The Scientific Basis. Contribution of Working Group I to the Third Assessment Report of the Intergovernmental Panel on Climate Change. Cambridge University Press, Cambridge, United Kingdom and New York, NY, USA: 881 pp.

Knap, W.H., Brock, B.W., Oerlemans, J. and Willis, I.C. 1999. Comparison of LandsatTM derived and ground-based albedo of Haut Glacier d'Arolla. International Journal of Remote Sensing, 20(17), 3293-3310.

Koelemeijer, R., Oerlemans, J. and Tjemkes, S. 1993. Surface reflectance of Hintereisferner, Austria, from Landsat 5 TM imagery. Annals of Glaciology, 17, 17-21.

Kuhn, M. 1985. Fluctuations of climate and mass balance: different responses of two adjacent glaciers. Zeitschrift für Gletscherkunde und Glazialgeologie, 21, 409-416.

Munro, D.S. 1991. A surface energy exchange model of glacier melt and net mass balance. International Journal of Climatology, 11, 689-700.

Oerlemans, J. 1986. An attempt to simulate historic front variations of Nigardsbreen, Norway. Theoretical and Applied Climatology, 37, 126-135.

Oerlemans, J. and Hoogendoorn, N.C. 1989. Mass-balance gradients and climatic change. Journal of Glaciology, 35(121), 399-405.

Oerlemans, J. and Fortuin, J.P.F. 1992. Sensitivity of glaciers and small ice caps to greenhouse warming. Science, 258, 115-117.

Oerlemans, J. 1994. Quantifying global warming from the retreat of glaciers. Science, 264: 243-245.

Oerlemans, J. 1997. A flow-line model for Nigardsbreen: projection of future glacier length based on dynamic calibration with the historic record. Annals of Glaciology, 24, 382-389.

Oerlemans, J. and Knap, W.H. 1998. A 1 year record of global radiation and albedo in the ablation zone of Morteratschgletscher, Switzerland. Journal of Glaciology, 44(147), 231-238.

Oerlemans, J., Anderson, B., Hubbard, A., Huybrechts, P., Jóhannesson, T., Knap, W.H., Schmeits, M., Stroeven, A.P., Van de Wal, R.S.W., Wallinga, J. and Zuo, Z. 1998. Modelling the response of glaciers to climate warming. Climate Dynamics, 14, 267-274 
Oerlemans, J. 2000. Analysis of a three-year meteorological record from the ablation zone of the Morteratschgletscher, Switzerland: energy and mass balance. Journal of Glaciology, 46(155), 571-579.

Oerlemans, J. 2001. Glaciers and Climate Change. Rotterdam, A.A. Balkema Publishers: 148 pp.

Oerlemans, J. and Klok, E.J., 2002. Energy balance of a glacier surface: analysis of AWS data from the Morteratschgletscher, Switzerland. Arctic, Antarctic and Alpine Research, 34(123), 115-123.

Paterson, W.S.B. 1994. The physics of glaciers. Pergamon Press, 3rd edition: 480 pp.

Sandmeier, S. and Itten, K.I. 1997. A physically-based model to correct atmospheric and illumination effects in optical satellite data of rugged terrain. IEEE Transactions on Geosciences and Remote Sensing, 35(3), 708-717.

Schneeberger, C., Albrecht, O., Blatter, H., Wild, M. and Hock, R. 2001. Modelling the response of glaciers to a doubling in atmospheric $\mathrm{CO}_{2}$ : a case study of Storglaciären, northern Sweden. Climate Dynamics, 17, 825-834.

Van de Wal, R.S.W., Oerlemans, J. and Van der Hage, J.C. 1992. A study of ablation variations on the tongue of Hintereisferner, Austrian Alps. Journal of Glaciology, 38(130), 319-324.

Wallinga, J. and Van de Wal, R.S.W. 1998. Sensitivity of Rhonegletscher, Switzerland, to climate change: experiments with a one-dimensional flowline model. Journal of Glaciology, 44(147), 383-393.

Warren, S.G. 1982. Optical properties of snow. Reviews of Geophysics and Space Physics, 20, 67-89. 


\section{TEMPORAL AND SPATIAL VARIATION OF THE SURFACE ALBEDO OF MORTERATSCH- GLETSCHER, SWITZERLAND, AS DERIVED FROM TWELVE LANDSAT IMAGES ${ }^{*}$}

Abstract - This investigation uses Landsat images from twelve days in 1999 and 2000 to study the spatial and temporal variation in surface albedo of a glacier with a rugged topography: Morteratschgletscher (Switzerland). Our retrieval method considers all processes that substantially influence the relationship between the satellite signal and the surface albedo. The correction for the anisotropy of the reflected radiation field of ice and snow ranges up to 0.10 , depending on wavelength band, solar zenith angle and surface type. We analysed the uncertainties in the retrieval method and mainly expect errors in satellitederived albedos for areas with large variation in topography and high albedos. The latter is due to application of parameterisations for the anisotropic correction to albedos outside the parameterisations' validity. On average, satellite-derived albedos exceed the measured surface albedo with 0.03 . The glacier tongue is characterised by bands of low and high albedo, relating to ice with higher and lower concentrations of debris. The ice albedo shows no dependence on altitude, except between 2000 and 2200 $\mathrm{m}$ a.s.l. It increases during summer, which is likely associated with rainfall, as concluded from a comparison between summer rainfall and measured albedos.

" Based on: Klok, E.J., Greuell, W. and Oerlemans, J. 2003. Temporal and spatial variation of the surface albedo of Morteratschgletscher, Switzerland, as derived from 12 Landsat images. Journal of Glaciology, accepted. 


\subsection{INTRODUCTION}

Net shortwave radiation is generally an important energy source for the melting process of glaciers. Therefore, glacier melt rates depend largely on the spatial and temporal variation of the surface albedo, which is the fraction of the incoming solar irradiance that is reflected by the surface. Albedo parameterisations used in energy and mass-balance models are often inadequate to represent the changes in the surface albedo in space and time and are consequently regarded as a main source of errors (e.g. Klok and Oerlemans, 2002 (Chapter 3); Arnold et al., 1996). A better knowledge of the variations in glacier albedo is needed to improve the current albedo parameterisations and mass-balance models.

Various groups have examined spatial and temporal variations in albedo of glaciers from field measurements and satellite images. Brock et al. (2000) measured the changes in albedo across Haut Glacier d'Arolla in Switzerland during two ablation seasons and developed a new albedo parameterisation scheme. Koelemeijer et al. (1993) were among the first who made use of satellite data to investigate the distribution of glacier albedo and its temporal evolution. They studied Landsat images of Hintereisferner (Austria). Later, Knap and Oerlemans (1996) and Greuell (2000) used satellite images to look at the spatial and temporal variation in albedo over west Greenland. Knap et al. (1999b) did a similar study for Haut Glacier d'Arolla (Switzerland), Reijmer et al. (1999) and De Ruyter de Wildt et al. (2002) for Vatnajökull (Iceland), and Stroeve et al. (1997) for the Greenland ice sheet. These studies used either Landsat 5 TM or Landsat 7 ETM+ data with a spatial resolution of $30 \mathrm{~m}$ or NOAA AVHRR data with a resolution of $1 \mathrm{~km}$.

The authors of these papers applied different methods to derive the surface albedo from the satellite data and made different assumptions. For instance, while Koelemeijer et al. (1993) did not correct for the slope of the surface, Knap et al. (1999b) did, but neglected the effect of elevation on the atmospheric correction, which according to Xin et al. (2002), must be considered in rugged mountainous areas. Often, the two-stream radiative model based on Slingo and Schrecker (1982) or the 6 S radiative-transfer model (Vermote et al., 1997) was used to accomplish the atmospheric correction. Stroeve et al. (1997) concluded that particularly uncertainties in the aerosol amounts affect the accuracy of this correction and that this can alter the derived albedo by 0.02 . In contrast, Knap at al. (1999b) stated that the atmospheric correction caused only minor errors in the derived albedo $(<0.01)$. They did not include aerosols in the radiative-transfer model and hypothesised that the role of aerosols is limited because aerosol emission sources are far away for this glacier at a high elevation. Stroeve et al. (1997) and De Ruyter de Wildt et al. (2002) were the only ones who corrected for the 
anisotropic nature of the reflected-radiation field of snow. Overall, omitting this correction is regarded as a main source of error. For example, Greuell and De Ruyter de Wildt (1999) estimated that for melting glacier ice, the mean albedo in TM band 2 increases with $0.10-0.12$ and in TM band 4 with 0.11-0.12 after correction for anisotropy. This was calculated from a TM image of Breidamerkurjökull (Iceland) with a solar zenith angle of $54^{\circ}$. To our knowledge, no attempt has yet been made to derive a glacier's albedo from satellite data while taking the anisotropy of both ice and snow into account.

The aim of the present work was to investigate the spatial and temporal variation of the surface albedo of a glacier. To achieve this, we studied a large series of Landsat data. The results are of interest for the modelling of spatial and temporal albedo changes within energy and massbalance models.

We derived surface albedos from twelve Landsat $5 \mathrm{TM}$ and Landsat 7 ETM+ images of Morteratschgletscher and Persgletscher (together called Morteratschgletscher; see Figure 2.1) in southeast Switzerland $\left(46^{\circ} 24^{\prime} \mathrm{N}\right.$, $\left.8^{\circ} 02^{\prime} \mathrm{E}\right)$. This constitutes a tough test as this glacier has a very steep and rugged accumulation zone. Morteratschgletscher's surface area is about 17 $\mathrm{km}^{2}$ and its current length is $7 \mathrm{~km}$. Its elevation ranges from 2000 to $4000 \mathrm{~m}$ a.s.l. The glacier mainly faces north and is surrounded by high mountains.

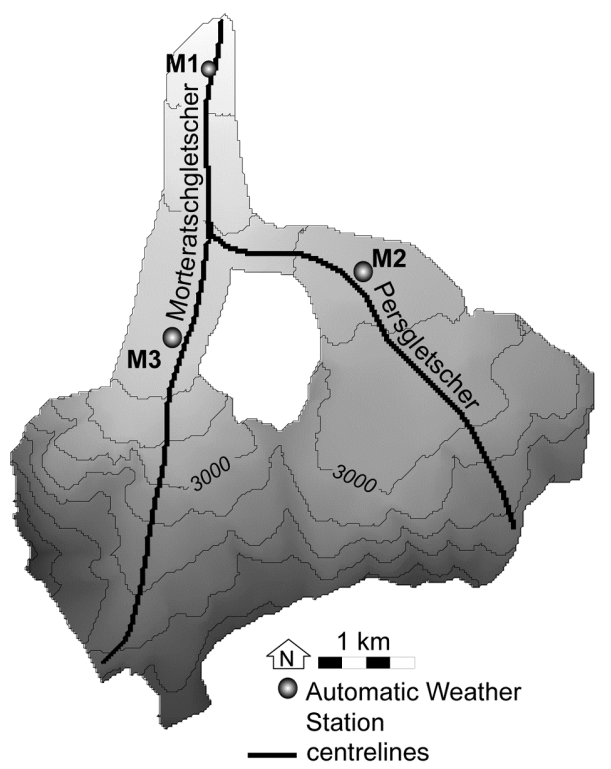

Figure 2.1: Map of Morteratschgletscher and Persgletscher, showing the locations of the automatic weather stations and the centrelines of the glaciers. The height contours are marked every $200 \mathrm{~m}$. 
We aimed to retrieve surface albedos while taking into account all important processes that influence the relationship between the satellite signal and the surface albedo, e.g. the role of aerosols in the atmosphere. Besides, we considered the topographic effects on direct and diffuse radiation, the reflected radiation from the surrounding terrain and the anisotropic nature of the reflection pattern of ice and snow.

In this chapter, we explain the retrieval method and discuss its uncertainties. The spatial and temporal variations in the satellite-derived surface albedo of Morteratschgletscher are presented and interpreted in Section 2.4. The Institute for Marine and Atmospheric Research, Utrecht (IMAU), has been operating three automatic weather stations on Morteratschgletscher (M1, M2 and M3, see Figure 2.1) and we describe a comparison of the satellite-derived albedos with ground measurements at M1. The last section of this chapter contains a summary and the conclusions.

Table 2.1: Dates, Landsat system and solar zenith angle of the twelve Landsat images and the percentage of glacier pixels that were omitted because of shading, saturation in band 4 , or a solar zenith angle relative to the surface exceeding $66^{\circ}$, and the total percentage that was omitted. The percentage of all pixels with an albedo of 0.95 and saturated in band 2 is also given.

\begin{tabular}{|c|c|c|c|c|c|c|c|c|}
\hline \multirow[b]{2}{*}{ Date } & \multirow{2}{*}{$\begin{array}{l}\text { Landsat } \\
5 \text { or } 7\end{array}$} & \multirow[b]{2}{*}{$\theta$} & \multicolumn{4}{|c|}{$\%$ of glacier satellite pixels omitted due to } & \multirow{2}{*}{$\begin{array}{l}\% \text { of pixels } \\
\text { with albedo } \\
\alpha=0.95\end{array}$} & \multirow{2}{*}{$\begin{array}{l}\% \\
\text { pixels } \\
\text { saturate } \\
\text { d in } \\
\text { band } 2\end{array}$} \\
\hline & & & shading & $\begin{array}{l}\text { saturated in } \\
\text { band } 4\end{array}$ & $\theta_{s}>66^{\circ}$ & total & & \\
\hline 13-3-1999 & 5 & $54^{\circ}$ & 37 & 1 & 20 & 58 & 47 & 2 \\
\hline 24-6-99 & 5 & $30^{\circ}$ & 4 & 3 & 8 & 15 & 6 & 13 \\
\hline 26-7-99 & 5 & $34^{\circ}$ & 6 & 0 & 9 & 15 & 1 & 1 \\
\hline 13-9-99 & 7 & $45^{\circ}$ & 19 & 2 & 19 & 40 & 1 & 9 \\
\hline 15-10-99 & 7 & $56^{\circ}$ & 48 & 2 & 20 & 70 & 6 & 51 \\
\hline $8-4-00$ & 7 & $43^{\circ}$ & 15 & 3 & 16 & 34 & 46 & 96 \\
\hline $9-5-00$ & 5 & $35^{\circ}$ & 7 & 3 & 10 & 20 & 11 & 12 \\
\hline $27-6-00$ & 7 & $28^{\circ}$ & 3 & 2 & 8 & 13 & 6 & 69 \\
\hline 21-7-00 & 5 & $33^{\circ}$ & 6 & 2 & 9 & 17 & 6 & 10 \\
\hline 21-8-00 & 7 & $39^{\circ}$ & 11 & 0 & 13 & 24 & 0 & 26 \\
\hline 15-9-00 & 7 & $46^{\circ}$ & 20 & 2 & 20 & 42 & 1 & 10 \\
\hline 24-10-00 & 7 & $60^{\circ}$ & 61 & 2 & 20 & 83 & 1 & 10 \\
\hline
\end{tabular}

\subsection{RETRIEVAL METHOD}

The twelve images, TM and ETM+ quarter scenes, that we chose (Table 2.1) were taken during cloudless days in spring, summer and autumn 
in 1999 and 2000 . Observations at two synoptic stations of Meteo Schweiz close to Morteratschgletscher (Robbia and Samedan) confirmed that the weather conditions were cloud free during the overpasses. First, we cut out subimages of $750^{\star} 750$ pixels of Morteratschgletscher and its surrounding area from the quarter scenes. Then, we geolocated these subimages by relating five to seven ground control points to Swiss map coordinates obtained from the 'Landeskarte der Schweiz', 1:25000 (1996).

The radiometric calibration was performed differently for TM and ETM+ data. For TM data, we used the spectral radiance ranges for each band provided with the Landsat data and the calibration coefficients of Teillet et al. (2001) to correct for the change in responsivity of the satellite sensors and estimate the radiance at satellite level from the raw data. The coefficients of Teillet et al. (2001) are based on a radiometric cross-calibration of Landsat 5 TM with the well-calibrated Landsat 7 ETM+ data for a period in June 1999. For ETM+, we followed the procedure of NASA (2001) to calculate the radiances. In contrast to TM, the reponsivity loss of ETM+ sensors is monitored by pre-launch and on-orbit calibration programmes, and changes in the responsivity are directly implemented in the processing of the data (NASA, 2001).

The planetary reflectance in each wavelength band, $r_{p l a, b}$, was calculated following Markham and Barker (1985):

$$
r_{p l a, b}=\frac{\pi \cdot R_{b} \cdot d^{2}}{E_{s u n, b} \cdot \cos (\theta)}
$$

where $R_{b}$ is the radiance at satellite level in the considered wavelength band (subscript $b$ ), $d$ is the Earth-Sun distance in astronomical units, $\theta$ is the solar zenith angle, and $E_{s u n, b}$ is the mean exo-atmospheric solar spectral irradiance in wavelength band $b$. Table 2.1 lists the solar zenith angle for the times at which our images were taken, which ranged between 9.13 and 10.01 UTC.

We applied the radiative transfer model 6S (Vermote et al., 1997) to account for atmospheric interference. From $6 \mathrm{~S}$, coefficients were determined to relate the reflectance of a horizontal glacier surface for each wavelength band, $r_{h o r, b}$, to the planetary reflectance, by following the relationship:

$$
r_{h o r, b}=a_{0, b}+a_{1, b} r_{p l a, b}+a_{2, b} r_{p l a, b}^{2}+a_{3, b} r_{p l a, b} z
$$

where $z$ is the altitude ( $\mathrm{m}$ a.s.l.) and $a_{0.3, b}$ are the coefficients determined with $6 \mathrm{~S}$. We estimated the altitude of each pixel from a digital elevation model (DEM) by interpolating four DEM pixels surrounding each satellite pixel, using a DEM of 1996 from the Bundesamt für Landestopographie of Switzerland (resolution is $25 \mathrm{~m}$ ). The residual standard deviation of 
Equation (2.2) did not exceed 0.0011, which does not necessarily imply that the overall uncertainty in the correction for the atmospheric interference is small. We will discuss this further in Section 2.3.3. Addition of higher-order terms to the right-hand side of the equation did not improve the performance of the fit. The coefficients of Equation (2.2) that we determined for the twelve images, revealed that the derived surface reflectance depends only slightly on altitude in spite of what Xin et al. (2002) argue. $r_{h o r, b}$ changed with about 0.01 between 2000 and $4000 \mathrm{~m}$ a.s.l. for a planetary reflectance of 0.80 .

The coefficients depend on the wavelength band, the illumination view geometry and the atmospheric composition. The latter is defined by the total ozone amount, visibility (from which aerosol optical thickness was derived), water vapour content and aerosol composition. We estimated visibility and water vapour content from data of a synoptic weather station of 'MeteoSchweiz' located in the area near Morteratschgletscher and a standard mid-latitude summer profile. Ozone was determined within NASA's Total Ozone Mapping Spectrometer (TOMS) project. We assumed a constant aerosol composition throughout the year: 5\% dust-like, 90\% watersoluble and 5\% soot. We estimated the effect of not taking aerosols into account on the atmospheric interference. For 21 August 2000, the planetary reflectance in band 2 would increase with $0.03-0.05$ and in band 4 with $0.02-0.03$ for surface reflectances ranging from 0.5 to 1.0 . Consequently, neglecting the effect of aerosols appears not justifiable for Morteratschgletscher. This is in agreement with the findings of Stroeve et al. (1997).

Because Morteratschgletscher is relatively steep and surrounded by high mountains, we considered the topographic effects on the derived surface reflectance. We therefore took into account direct and diffuse radiation and the reflected radiation coming from surrounding slopes. Firstly, the direct part of the irradiance was corrected for the surface inclination. Secondly, the diffuse radiation, which is a function of the sky hemisphere not obstructed by the surrounding mountains, was calculated using the sky view factor, Vsky, as defined by Dozier and Frew (1990). Lastly, the amount of reflected radiation from the surrounding terrain was estimated following Richter (1987). Accounting for these three radiation components, we derived the following equation to calculate the surface reflectance of a tilted surface, $r_{s, b}$, from the reflectance of a horizontal surface:

$$
r_{s, b}=r_{h o r, b} \frac{1}{V_{s k y} f_{d i f}+f_{d i r} \frac{\cos \left(\theta_{r}\right)}{\cos (\theta)}+V_{t e r}\left\langle r_{s, b}\right\rangle}
$$


The terrain view factor, $V_{t e r}$, was calculated after Dozier and Frew (1990). $\theta_{r}$ is the solar zenith angle relative to the surface-parallel plane. We calculated this angle for each satellite pixel from four DEM pixels surrounding that satellite pixel. The direct $\left(f_{\text {dir }}\right)$ and diffuse $\left(f_{\text {dif }}\right)$ fraction of the solar irradiance was calculated from $6 \mathrm{~S} .<r_{s, b}>$ is the average reflectance of the adjacent pixels (a box of $61^{*} 61$ pixels). Three iterations were needed for the convergence of the average terrain reflectance to obtain a deviation less than $1 \%$.

For isotropic reflecting surfaces, the surface reflectance calculated from Equation (2.3) equals the surface albedo. However, for ice and snow surfaces, the reflected radiation field is anisotropic. To account for this and calculate the surface band albedo $\left(\alpha_{s, b}\right)$, we divided the surface reflectance from Equation (2.3) by the anisotropic reflection factor, $f$ :

$$
\alpha_{s, b}=\frac{r_{s, b}}{f\left(\theta_{r}, \theta_{v}, \varphi\right)}
$$

where $\varphi$ is the relative view azimuth angle and $\theta_{v}$ the satellite zenith angle with respect to the inclined surface. The anisotropic reflection factor depends on the illumination view geometry and is a surface dependent function. It differs for ice and snow owing to their different surface reflection patterns. We calculated $f$ from BRDFs (Bi-directional Reflection Distribution Functions) derived for ice by Greuell and De Ruyter de Wildt (1999) and for snow by Koks (2001). Table 2.2 proves that a correction for anisotropy (difference between $\alpha_{s, b}$ and $r_{s, b}$ ) is important for large solar zenith angles. It also shows that the correction for anisotropy increases for larger wavelength bands and is greater for ice than for snow surfaces.

Table 2.2: Mean correction for anisotropy with standard deviation of the distribution for satellite-derived albedos of Morteratschgletscher for band 2 $(0.53-0.61 \mu \mathrm{m})$ and $4(0.78-0.90 \mu \mathrm{m})$, for ice and snow, and two days.

\begin{tabular}{lllll}
\hline \multirow{2}{*}{ Surface type } & \multicolumn{2}{l}{$24-6-1999\left(\theta=30^{\circ}\right)$} & \multicolumn{3}{l}{$15-10-1999\left(\theta=56^{\circ}\right)$} \\
\cline { 2 - 5 } & Band 2 & Band 4 & Band 2 & Band 4 \\
\hline Snow & $-0.009 \pm 0.001$ & $0.019 \pm 0.036$ & $0.022 \pm 0.023$ & $0.081 \pm 0.048$ \\
Ice & $0.031 \pm 0.033$ & $0.036 \pm 0.040$ & $0.089 \pm 0.038$ & $0.099 \pm 0.037$ \\
\hline
\end{tabular}

Finally, we calculated the broadband albedo from the albedo in bands 2 and 4, following the parameterisation of Knap et al. (1999a):

$$
\alpha=0.726 \alpha_{s, 2}-0.322 \alpha_{s, 2}^{2}-0.051 \alpha_{s, 4}+0.581 \alpha_{s, 4}^{2}
$$


If band 2 was saturated, we used a parameterisation that depends only on the albedo in band 4 (Knap et al., 1999a):

$$
\alpha=0.782 \alpha_{s, 4}+0.148 \alpha_{s, 4}^{2}
$$

We used these empirical relationships because they were established from ground-based simultaneous measurements of $\alpha_{s, 2}, \alpha_{s, 4}$ and $\alpha$ over different glacier surface types on the tongue of Morteratschgletscher. We expect that they estimate the broadband albedo accurately as the residual standard deviations of Equations (2.5) and (2.6) are only 0.009 and 0.014 respectively (Knap et al., 1999a). Saturation in band 2 often occurred for the images in spring and autumn (see Table 2.1). Especially on 8 April 2000 and 27 June 2000, a large part of the image was saturated. Both images are from Landsat 7 ETM+, which is more often saturated in band 2 than Landsat 5 TM because its spectral radiance range is $80 \%$ smaller than for band 2 of Landsat 5 TM.

As mentioned, the BRDF parameterisations differ for ice and snow, but whether an area is ice or snow is not known beforehand. We solved this problem by calculating broadband albedos with both BRDF parameterisations. Then, we assumed that areas that had a calculated surface albedo smaller than 0.5 with both BRDF parameterisations represented ice. We supposed that pixels having a calculated surface albedo larger than 0.5 with both BRDF parameterisations pertained to snow. We left out the remaining pixels unless the difference between the two values did not exceed 0.1 , in which case we used the mean value. The number of pixels that were omitted was very small for most images: normally $<0.1 \%$. We based the threshold albedo of 0.5 to distinguish between ice and snow on albedo observations made on Morteratschgletscher by Knap et al. (1999a). Surface albedos that exceeded 0.95 were set to 0.95 , which is about the highest snow albedo measured (Paterson, 1994).

We did not calculate albedos for all satellite pixels. We omitted: (I) pixels that were not assigned as 'glacier', defined by a glacier overlay derived from the 'Landeskarte der Schweiz'; (II) pixels that were shaded, as calculated from a shading routine after Dozier and Frew (1990); (III) pixels that were saturated in band 4; and (IV) pixels for which the solar zenith angle relative to the inclined surface was larger than $66^{\circ}$ because the BRDF parameterisations are not valid for these zenith angles (see Table 2.3). We did not exclude pixels having an albedo outside the albedo ranges of the BRDF parameterisations because this leads to a incorrect distribution in the surface albedo. E.g., if all albedos larger than 0.74 were omitted, the mean derived glacier albedo would be too low. Table 2.1 shows that most pixels were omitted because they were shaded or the solar zenith angle relative to their surface was too large. Saturation in band 4 rarely occurred. 
Table 2.3: Ranges of BRDF parameterisations of ice (Greuell and De Ruyter de Wildt, 1999) and snow (Koks, 2001).

\begin{tabular}{lllll}
\hline & Ice & \multicolumn{3}{l}{ Snow } \\
\cline { 2 - 5 } & Minimum & Maximum & Minimum & Maximum \\
\hline Solar zenith angle & $26.4^{\circ}$ & $74.2^{\circ}$ & $15.91^{\circ}$ & $65.51^{\circ}$ \\
Albedo in band 2 & 0.197 & 0.670 & 0.742 & 0.984 \\
Albedo in band 4 & 0.155 & 0.601 & 0.654 & 0.897 \\
Broadband albedo & 0.14 & 0.50 & 0.55 & 0.74 \\
\hline
\end{tabular}

\subsection{UNCERTAINTIES IN THE RETRIEVAL METHOD}

Before discussing the results, it is important to know the uncertainties in the retrieval method and how they influence the albedo calculation. In this way, we are able to give a better explanation for the spatial and temporal patterns shown by the satellite-derived albedos of the glacier. We estimated all uncertainties given in this section for 21 August 2000. This Landsat image contains both snow and ice areas and the solar zenith angle is approximately the average solar zenith angle of the twelve images. Table 2.4 summarises the estimated uncertainties.

Table 2.4: Uncertainties in the derived surface albedo of 21 August 2000.

\begin{tabular}{ll}
\hline Source of uncertainty & Uncertainty \\
\hline Topography & 0.05 \\
Radiometric calibration & 0.02 \\
Atmospheric composition & 0.01 \\
Diffuse, direct and reflected radiation & 0.01 \\
BRDF parameterisations & $0.01-0.05$ \\
Narrow-to-broadband conversion & 0.01 \\
\hline
\end{tabular}

\subsubsection{TOPOGRAPHY}

The corrections for diffuse, direct and reflected radiation and anisotropy depend largely on the topography calculated for each grid cell. The uncertainty in the calculated topography is produced by the resolution of the DEM and the derived surface slope, and also by the accuracy of the geolocation of the subimages. Richter (1998) demonstrated that for incident angles $\theta_{r}<60^{\circ}$, the surface band albedo is not sensitive to slope errors. For $\theta_{r}=66^{\circ}$, which is the maximum angle we allow for albedo retrieval, a slope error of $3^{\circ}$ causes a relative error in the band albedo in the order of $10 \%$ (Richter, 1998). 
We expect that the accuracy of the image geolocation influences the calculated surface topography and the derived surface albedo to a larger extent. We investigated errors associated with this by replacing the elevation, aspect and slope of each image pixel $(i, j)$ by the topography of its neighbouring pixel. This was done in four directions $(i \pm 1, j \pm 1)$. This led to a standard deviation of 0.05 in the glacier's surface albedo. The effect was larger for altitudes above $3000 \mathrm{~m}$ a.s.l. (0.07) than for lower altitudes (0.02), which is due to the larger variation in topography at higher altitudes (see Figure 2.2). Thus, the accuracy of the geolocation is important for the albedo retrieval of a single satellite pixel, but averaged over the entire glacier, the mean change in the surface albedo is small when for each pixel the topography of the adjacent pixel is used $(<0.01)$.

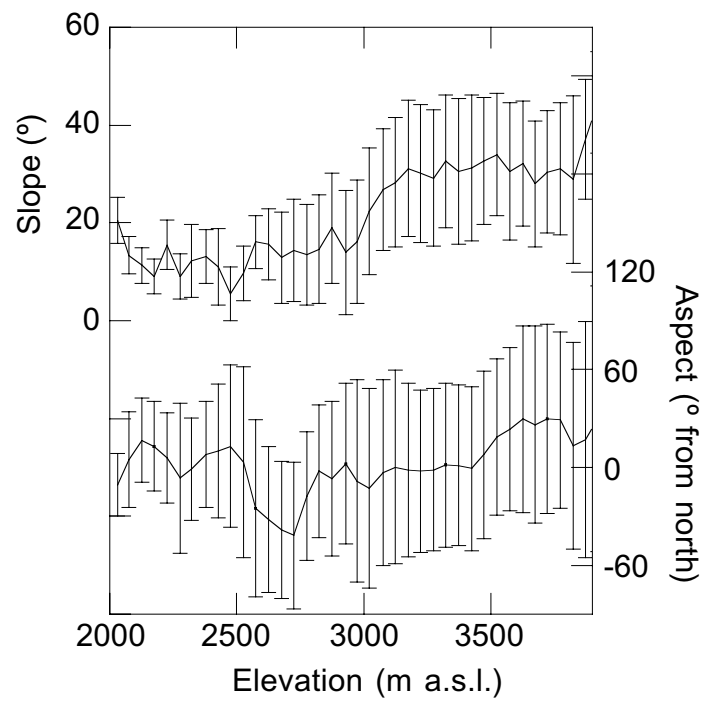

Figure 2.2: Slope and aspect of Morteratschgletscher averaged over 50-m height intervals. The error bars indicate the standard deviation of the distribution.

\subsubsection{RADIOMETRIC CALIBRATION}

Usage of the appropriate set of the spectral radiance ranges provided with each Landsat 7 ETM+ image ensures an accurate conversion to radiance units of 5\% (NASA, 2001). The coefficients that we used for the radiometric correction of Landsat $5 \mathrm{TM}$ data were derived by Teillet et al. (2001), who estimated the uncertainty in these coefficients at $6 \%$. Hence, we changed the coefficients for the radiometric calibration by $6 \%$ and found a standard deviation in the surface albedo of 0.02 . 


\subsubsection{ATMOSPHERIC COMPOSITION}

To estimate the uncertainty regarding the atmospheric correction, we changed some of the input values of 65 , namely those concerning information about the atmospheric composition. Differences in the planetary reflectance resulting from changes in the atmospheric composition were estimated as function of the surface albedo (Figure 2.3). The data of 21 August 2000 and an altitude of $2500 \mathrm{~m}$ a.s.l defined the reference state. An increase in water vapour, ozone concentration, or a reduction in the visibility did not affect the planetary reflectance significantly. Doubling the soot concentration from $5 \%$ to $10 \%$ at the expense of water-soluble aerosols had the largest effect on the atmospheric correction. This effect is larger in band 2 because scattering by aerosols is more effective at smaller wavelengths. Changing the relative amounts of other aerosol types turned out to have a negligible effect on the atmospheric correction. We estimated the impact of the uncertainty in the soot concentration on the surface albedo of Morteratschgletscher by doubling the soot. This resulted in a standard deviation of the surface albedo of 0.01 .
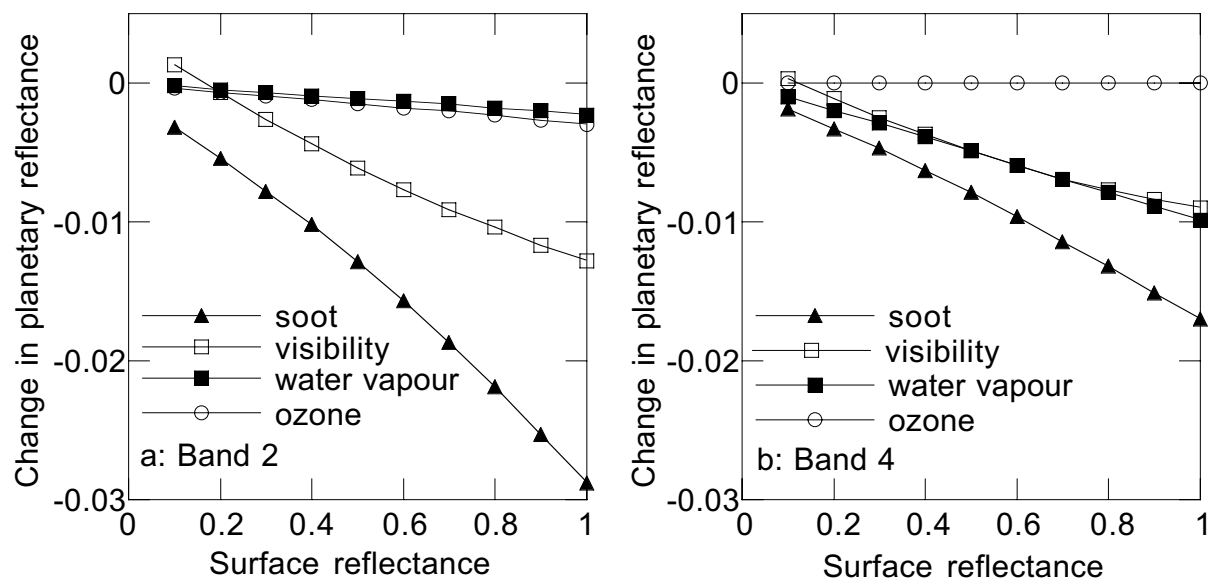

Figure 2.3: Change in planetary reflectance as function of the surface reflectance for band $2(a)$ and $4(b)$, calculated from $6 S$ for 21 August 2000 for different changes in input parameters: increase in soot concentration from $5 \%$ to $10 \%$, decrease in visibility from $45 \mathrm{~km}$ to $30 \mathrm{~km}$, increase in water vapour amount by $50 \%$, and increase in ozone concentration by $5 \%$.

\subsubsection{DIFFUSE, DIRECT AND REFLECTED RADIATION}

Uncertainties in the corrections to account for diffuse, direct and reflected radiation arise from the calculated surface topography and the appropriate parameterisation for the topographic effects. We already discussed the first source of error in Section 2.3.1. Parameterisations to 
correct satellite imagery for topographic effects are well discussed by Richter (1998), Sandmeier and Itten (1997) and Proy et al. (1989). We followed an approach similar to Richter (1998), but neglected the anisotropic contribution of the diffuse radiation. Compared to Proy et al. (1989), we used a less sophisticated method to account for the terrain reflection. In order to estimate the errors involved in using a less sophisticated method, we calculated the contribution of the topographic effects for the glacier albedo of Morteratschgletscher using Equation (2.3).

Assuming that all radiation is direct $\left(f_{d i f}=0\right)$ resulted in a standard deviation in the surface albedo of 0.02. Separating direct and diffuse radiation, but not accounting for the obstruction of the sky hemisphere $\left(V_{s k y}=1\right)$, led to a standard deviation of 0.01 . Neglecting the reflection from the adjacent slopes $\left(V_{t e r}=0\right)$ caused a standard deviation of 0.02 . The contributions are thus relatively small for 21 August 2000. Based on these results, we expect that a more sophisticated model would not change the derived surface albedo by more than 0.01 . However, for areas with higher surface albedos, the contributions would be larger. For example, for the areas with a surface albedo $>0.6$, exclusion of the terrain reflection resulted in a standard deviation of 0.05 .

\subsubsection{BRDF PARAMETERISATIONS}

Table 2.3 shows the ranges within which the BRDF parameterisations should be applied. In spite of this, we extrapolated the BRDF parameterisations beyond these ranges regarding the surface albedo (not regarding the solar zenith angle). We also applied the BRDF parameterisation of ice to areas covered with debris, for which it actually does not apply. We assumed that a correction for the anisotropy of a surface outside the range of the parameterisations would be better than applying no correction at all. The errors involved in these assumptions are unknown and are difficult to estimate because we do not know the bidirectional reflection pattern of (debris-covered) ice with very low albedos or snow with very high albedos. We expect that the error will be smaller than the magnitude of the correction. Therefore, we estimated the uncertainty in the anisotropic correction for these albedos at half the anisotropic correction. This implies 0.03 in both bands for albedos smaller than 0.15 , and 0.01 in band 2 and 0.04 in band 4 for albedos larger than 0.74 . Note that these numbers were calculated from data of 21 August 2000. For days with larger solar zenith angles, the uncertainty would be larger. For instance for 15 October 1999: 0.02 in band 2 and 0.07 in band 4 for albedos larger than 0.74 .

In addition, there are uncertainties associated with the fact that the BRDF parameterisations are based on measurements obtained at only a few locations: for ice on Morteratschgletscher (Greuell and De Ruyter de Wildt, 1999), and for snow on Glacier du Géant (Italy) (Koks, 2001). These 
measurements were done on flat surfaces. Surface roughness, such as sastrugi, can alter the bidirectional reflectance patterns significantly (Warren et al., 1998). As the surface of Morteratschgletscher is relatively flat, we expect that this effect does not play an important role. Moreover, it is questionable if the parameterisations represent all the ice and snow surfaces of Morteratschgletscher, since they are based on measurements from only a few locations. If we assume that the error involved in this is half the anisotropic correction, it might range between 0.01 and 0.05 depending on the wavelength band, the surface type and especially the solar zenith angle (see Table 2.2).

\subsubsection{NARROW-TO-BROADBAND CONVERSION}

The narrow-to-broadband albedo parameterisations make an accurate estimate of the broadband albedo, according to the low residual standard deviations of Equations (2.5) and (2.6), mentioned in Section 2.2. Therefore, we also expect that the effect of saturation in band 2 does not appear to influence the calculation of the surface albedo significantly.

\subsection{RESULTS AND INTERPRETATION}

\subsubsection{SPATIAL DISTRIBUTION OF THE SURFACE ALBEDO OF THE ENTIRE GLACIER}

Figure 2.4 shows the derived glacier surface albedo for 5 Landsat images of 1999. In March, the glacier was covered by snow. The derived surface albedo was 0.95 for $47 \%$ of the area (see also Table 2.1), which seems rather high. This could be ascribed to uncertainties in the correction for anisotropy because only $29 \%$ of the pixels were within the albedo ranges of the BRDF parameterisation for snow. The black areas on the tongue, visible in March and October, are steep areas where pixels were omitted because of shading.

From June to September, the area with exposed glacier ice increased. The images reveal that the glacier tongue consisted of clean glacier ice in the middle, surrounded by ice with a significantly lower albedo (0.15), owing to debris. Where glacier ice is exposed, the lateral variation in albedo appears to exceed the altitudinal variation in albedo in the ablation area. The images do not clearly indicate the position of the snowline, except for 26 July, for which a sharp transition in the surface albedo is visible on Persgletscher. Sometimes, areas with low surface albedos are found for the highest altitudes, which is not exactly what one might expect. This could be due to parts of the mountain tops not being covered with snow, but these findings also support the notion that the albedo retrieval method is not accurate for areas with a large variation in surface topography (Figure 2.2). 


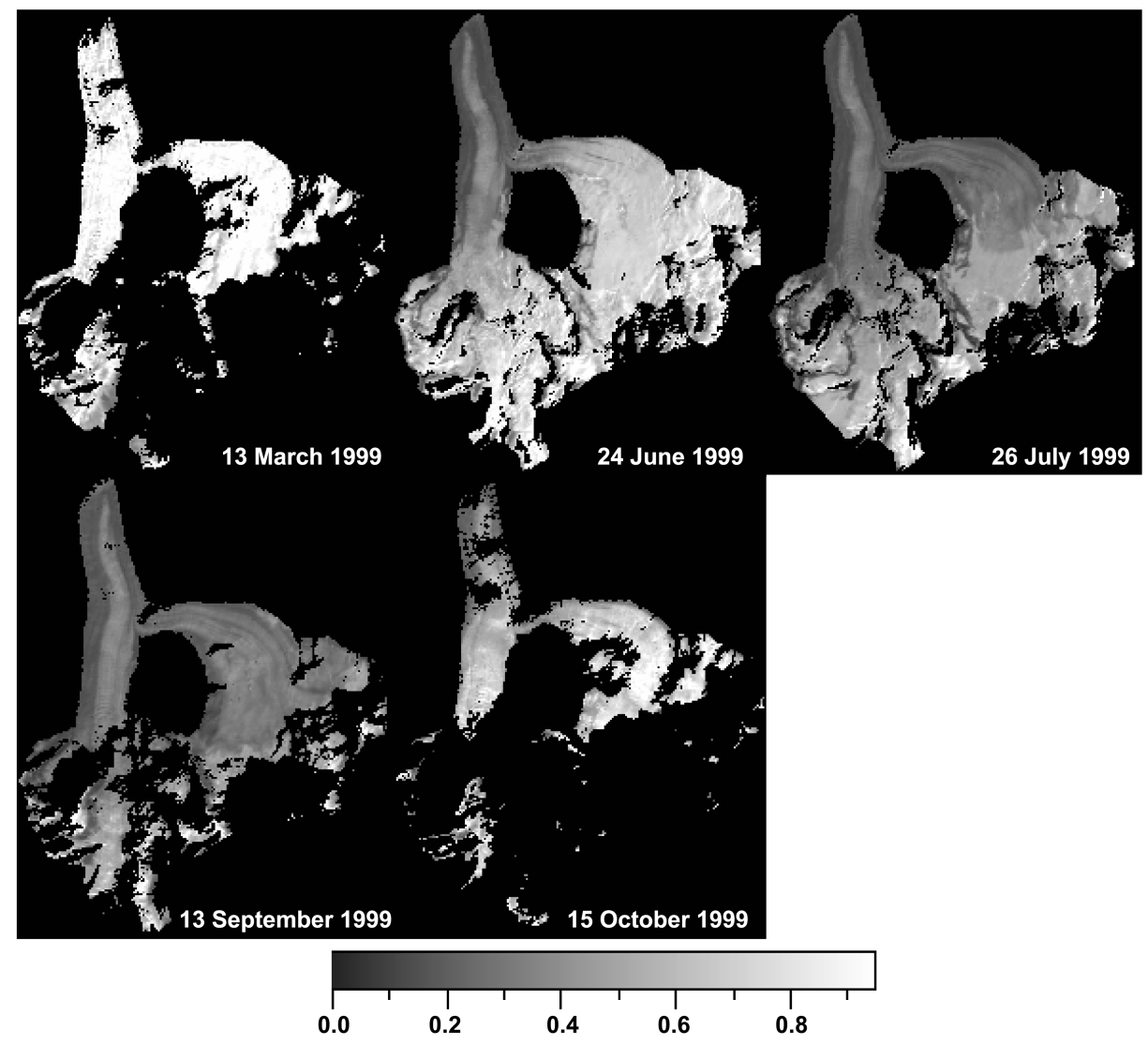

Figure 2.4: Spatial distribution of Landsat derived albedos for Morteratschgletscher for the images of 1999.

\subsubsection{Albedo of the ablation area}

Figure 2.5 shows the mean albedo of the ablation area, defined here as the area below $3000 \mathrm{~m}$ a.s.l. The mean albedos in March and April were very high $(>0.9)$, but became small in summer. The lowest mean albedo was derived for 21 August 2000 (0.25). For the summer values, the standard deviation is smaller because at that time, most of the ablation area is snowfree. Between 27 June and 21 July 2000, the glacier albedo increased by 0.09 owing to a summer snowfall event on 11 July 2000. A sonic ranger located at M1 (see Figure 2.1) registered this event. The mean albedos calculated from the images of October are probably biased towards lower values because a large part of the ablation area was omitted due to shading or large solar zenith angles relative to the inclined surface. These pixels mostly represented the higher locations where the topography is steeper (Figure 2.2) and the albedos likely higher. 


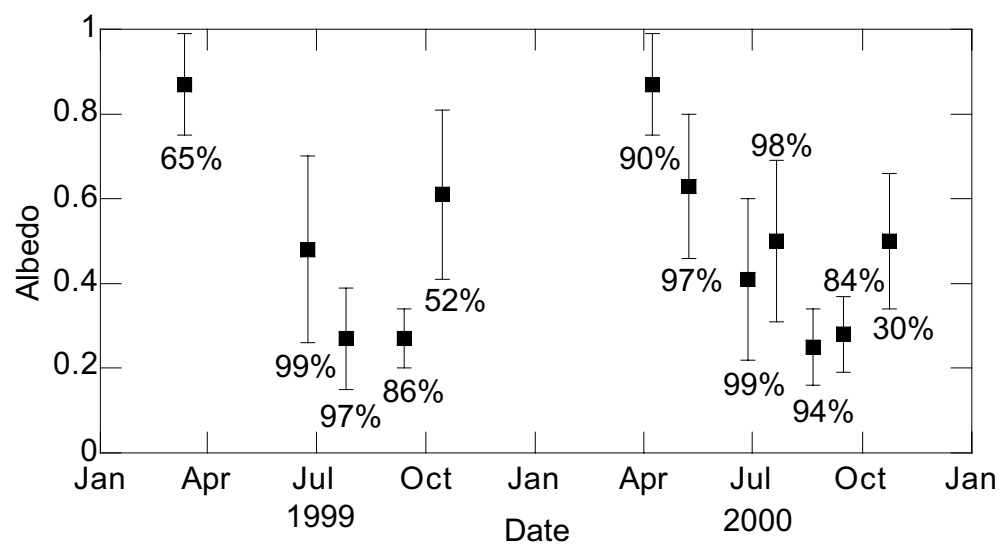

Figure 2.5: Mean albedo of ablation area $(<3000 \mathrm{~m}$ a.s.l.) derived from twelve Landsat images. The error bars show the standard deviation of the distribution. The percentages indicate the fraction of pixels of the total ablation area not omitted, for reasons given in Table 2.1.
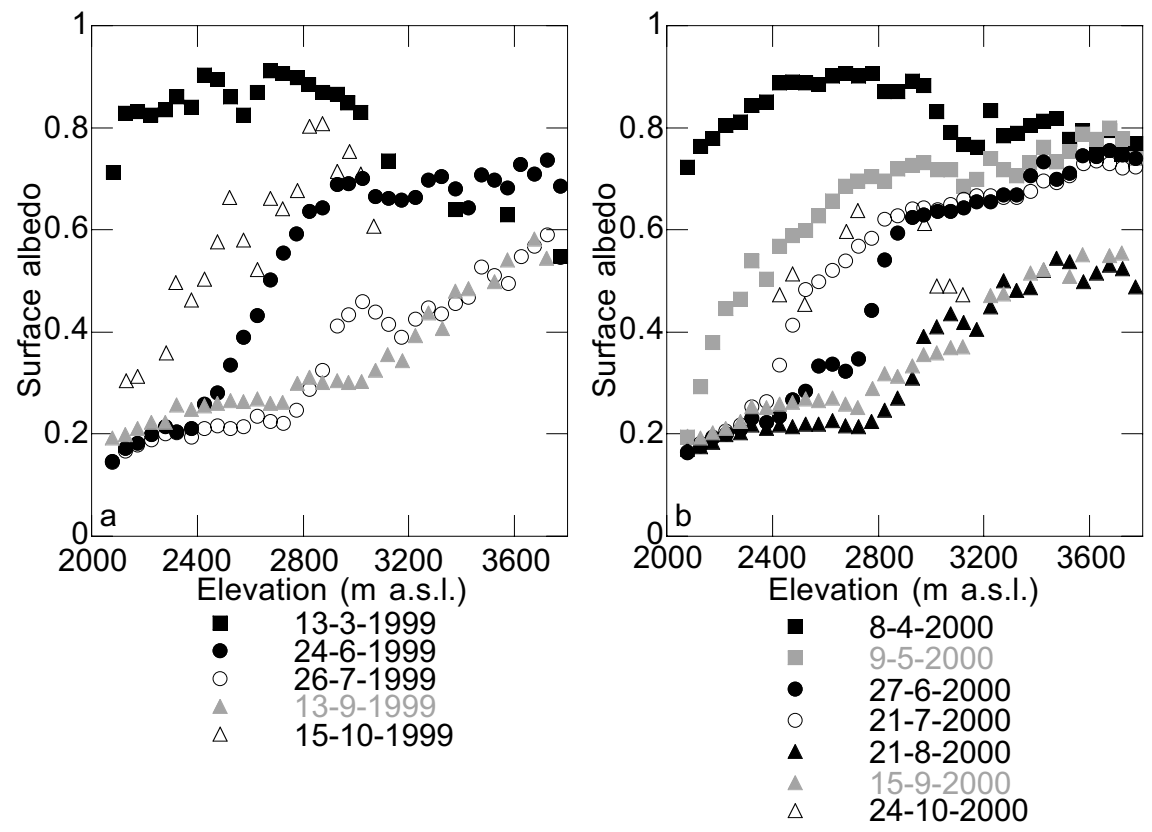

Figure 2.6: Mean albedo for 50 m-height intervals derived from twelve Landsat images as function of elevation for 1999 (a) and 2000 (b).

\subsubsection{MEAN ALBEDO OVER HEIGHT INTERVALS}

Figure 2.6 shows satellite-derived glacier albedos averaged over 50-m height intervals as function of altitude for all days. We did not take 
averages for height intervals of which more than $50 \%$ of the grid cells were omitted. In March and April, the glacier was totally covered with snow, which is reflected in very high albedos. In May and June, snow gradually melted away and the snowline moved up-glacier to $2680 \mathrm{~m}$ a.s.l. on 24 June 1999 and $2800 \mathrm{~m}$ a.s.l. on 27 June 2000. (We define the snowline as the altitude at which the albedo is 0.5.) In June, the albedo was about 0.2 at the glacier tongue and between 0.65 and 0.8 at high elevations. The glacier albedo increased at almost all elevations between 27 June and 21 July 2000, as a result of the summer snowfall event. The snowline reached an altitude of $3500 \mathrm{~m}$ a.s.l. on 13 September 1999 and $3350 \mathrm{~m}$ a.s.l. on 15 September 2000. Whereas the snowline had moved up-glacier, the ice albedo at the lower parts of the glacier had increased. Between 26 July and 13 September 1999, the average albedo over the glacier tongue (from 2000 to $2800 \mathrm{~m}$ a.s.l.) increased with about 0.04. Between 21 August and 15 September 2000, the albedo increased with about 0.03. Koelemeijer et al. (1993) and Brock et al. (2000) observed this as well. The latter suggested that glacier albedo can increase due to the removal of debris by rainfall, which we will discuss in more detail in Section 2.4.6.

\subsubsection{Albedo AlONG TWO CENTRELINES}

We calculated mean albedos along a centreline over Morteratschgletscher and a centreline over Persgletscher (Figure 2.1) to investigate differences in the surface albedo of the two glaciers. Means were derived from squares of $3^{*} 3$ satellite pixels from five images of the year 2000 and are shown as function of elevation in Figure 2.7. The mean centreline albedos exceed the albedos averaged over 50-m height intervals (Figure 2.6) because the centrelines are located within areas of little debris. The increase in the albedo between 27 June and 21 July due to the snowfall event (on 11 July) shows up in Figure 2.7b and 2.7c. All figures show a large scatter in albedo towards higher elevations. These fluctuations are probably associated with the large variation in topography (Figure 2.2).

It is striking that the albedo values of Morteratschgletscher often exceed the values of Persgletscher between 2450 and $2700 \mathrm{~m}$ a.s.l. Persgletscher is very crevassed between 2460 and $2600 \mathrm{~m}$ a.s.l. and this partly explains this difference in albedos. Other possible explanations are differences in snow accumulation and melt rate. Morteratschgletscher is located between steep slopes, which probably leads to more snow accumulation caused by snowdrift. Snow accumulation data from the sonic rangers M2 on Persgletscher and M1 and M3 on Morteratschgletscher of the winter period 1999-2000 (Figure 2.1) show indeed a larger increase in snow

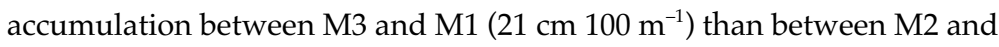

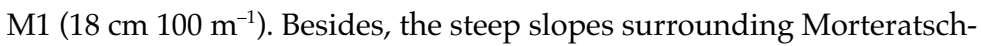
gletscher cast shadows on the glacier (Klok and Oerlemans, 2002 (Chapter 3)), 

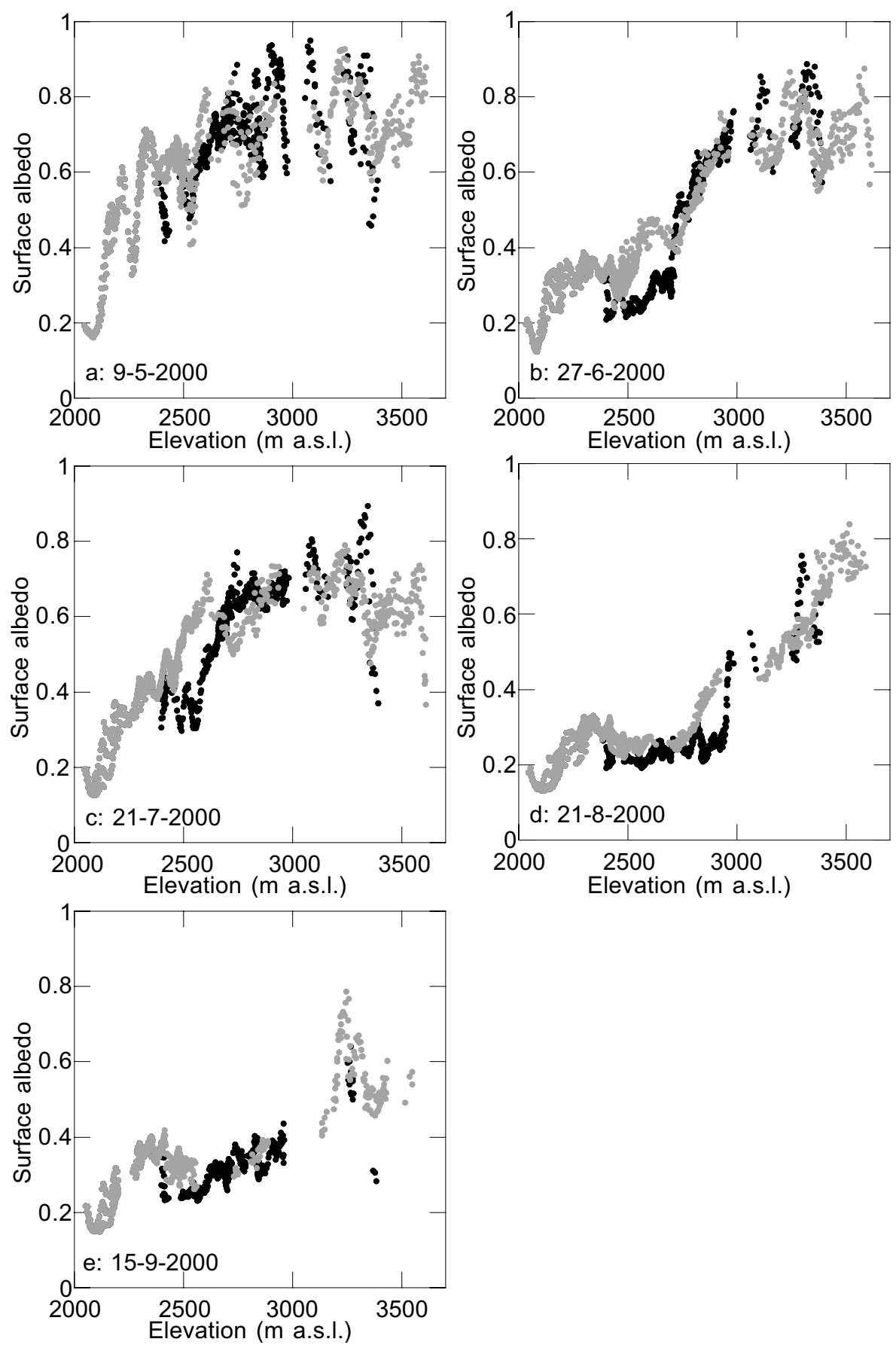

Figure 2.7: Mean albedos along the centreline of Morteratschgletscher (grey) and Pers-gletscher (black) (see Figure 2.1) derived from Landsat images. The mean albedos are averages of nine pixels. 
causing less incoming solar radiation on the glacier and thus reducing the melt rate. The albedos along the centrelines also reveal a crevassed area located around $2750 \mathrm{~m}$ a.s.l. on Morteratschgletscher.

Looking at the glacier ice areas up to $2900 \mathrm{~m}$ a.s.l. of 21 August and 15 September 2000 (Figure 2.7d and 2.7e), the ice albedo does not show an increase with altitude. This is often assumed due to increased debris concentrations at lower parts of the glacier (Oerlemans, 1992). We only see an increase in the albedo with elevation between 2000 and $2200 \mathrm{~m}$ a.s.l., and this certainly is associated with differences in the debris amount.

\subsubsection{COMPARISON WITH GROUND MEASUREMENTS}

An automatic weather station at M1 (Figure 2.1) measures incoming and reflected shortwave radiation (Oerlemans and Knap, 1998). Satellitederived albedos were compared to albedos derived from these radiation measurements for the time the satellite passes over (Figure 2.8). The satellite-derived pixels were averaged over a square of $3 * 3$ pixels. On average, satellite-derived albedos exceed the measured surface albedo with 0.03 , and the standard deviation is 0.07 . However, the satellite-derived albedo of 13 March 1999 is 0.14 larger than the measured albedo. This is likely due to the application of the BRDF parameterisations to albedos outside their validity ranges for snow.

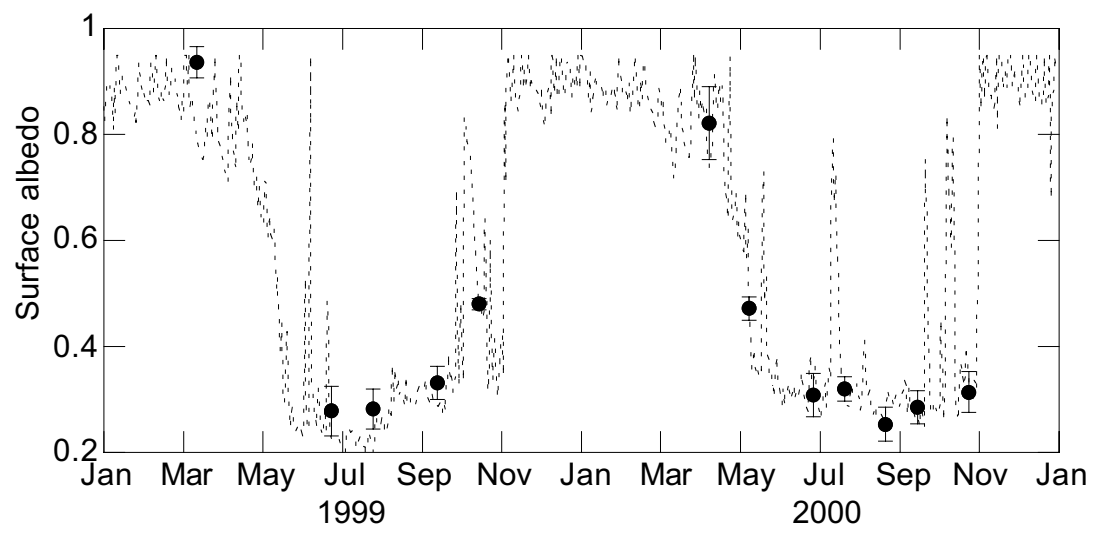

Figure 2.8: Mean measured albedo from the automatic weather station at M1

(Figure 2.1) at the time of the satellite overpasses (between 9.00 and 10.00 UTC) (dotted line) and mean satellite-derived albedo (black dots) of nine pixels around M1 for two years. The error bars show the standard deviation of the nine pixel values. 


\subsubsection{RELATION BETWEEN RAINFALL AND AN INCREASE IN SURFACE ALBEDO}

We calculated an average increase of 0.02 in the glacier albedo for height intervals below $3000 \mathrm{~m}$ a.s.l. between July and September 1999 and estimated this at 0.03 for between August and September 2000 (Figure 2.6). For 2000, this increase in glacier albedo towards September is also reflected in Figure 2.5 by an increase in the mean albedo over the entire ablation area. In addition, Figure 2.7 shows an increase (of about 0.06 ) in the ice albedo along the centreline of Morteratschgletscher, and the satellite-derived surface albedo for M1 increased with 0.09 between July and September 1999 and with 0.04 from August to September 2000 (Figure 2.8). Data of the sonic ranger located at $\mathrm{M} 1$ prove that this feature cannot be explained by summer snowfall events only. Brock et al. (1999) suggested that rainfall removes debris from the glacier, resulting in an increasing albedo during the summer season.

To test this hypothesis, we compared daily rainfall rates with the change in albedo between two days measured by the automatic weather station at M1 (Figure 2.1). Albedo measurements from this station of the years 1996 to 2000 also demonstrated that the albedo at M1 increases over the months July to September, on average by 0.08 . This can be seen in Figure 2.8 for 1999, but this increase does not show up for 2000. We used precipitation data from Bernina Curtinatsch, located $5 \mathrm{~km}$ northeast of Morteratschgletscher at $2095 \mathrm{~m}$ a.s.l., of the months July to September of 1996 to 2000. Summer snowfall events were excluded from the data set. Analysis of the daily rainfall data and changes in daily albedo proved that during $83 \%$ of the 82 days on which daily precipitation exceeded $5 \mathrm{~mm}$, an increase in the albedo was measured. The mean increase in albedo was 0.03 . It supports the notion that rainfall washes away debris from the glacier surface and that this leads to an increase in the glacier albedo. Therefore, rainfall may have caused the increase in surface albedo towards September shown by the satellite data.

\subsection{SUMMARY AND CONCLUSIONS}

This research investigated the spatial and temporal variation in the surface albedo of a glacier with a very rugged accumulation area by studying a large number of Landsat TM and ETM+ images. Satellite data of Morteratschgletscher of twelve days in 1999 and 2000 were used. We studied the retrieval method thoroughly and tried to consider all important processes that influence the relationship between the signal received by the satellite and the surface albedo within the retrieval method. We took into account the anisotropy of both ice and snow, which to our knowledge has not yet been attempted before. The good agreement between Landsatderived albedos and albedo measurements from an automatic weather 
station on the glacier tongue leads us to believe that the retrieval method generally generates accurate estimates of the glacier albedo.

However, the retrieval method does not perform well for snowcovered areas with high albedos. We base this conclusion on very large satellite-derived albedos (>0.95) for spring. This is likely due to the correction for anisotropy since we sometimes applied the BRDF parameterisations for snow to surface albedos - particularly high albedos that fell beyond the validity ranges of these parameterisations. We think that the application of the BRDF parameterisations may have lead to errors of up to 0.07 in these derived surface albedos. The mean anisotropic correction ranges up to 0.10 for satellite-derived surface albedos of Morteratschgletscher, depending on the solar zenith angle, the surface type and the wavelength band.

Also, for rugged areas with a large variation in surface slope and aspect, the uncertainty in the surface albedo appears to be large. We derive this conclusion from observations for areas with low satellite-derived surface albedos at high altitudes and a larger scatter in satellite-derived albedos at high altitudes. It is associated with estimation of slope and aspect of each pixel, influencing the correction for topographic effects (Equation (2.3)) and anisotropy (Equation (2.4)). Mean errors in the surface albedo of up to 0.07 can be expected for individual pixels at altitudes higher than 3000 $\mathrm{m}$ a.s.l. owing to the inaccuracy of the image geolocation, which results in a different topography for each satellite pixel.

Errors related to the uncertainties in atmospheric composition and in the narrow-to-broadband conversion are small. In order to improve the retrieval method, it would be useful to determine BRDFs for a wider range of surface albedos, solar zenith angles and surface conditions. However, we expect that an accurate assessment of albedos for areas with a large variation in slope will remain difficult.

The results show that the ice of the glacier tongue is characterised by longitudinal bands with a more or less constant albedo. A band in the middle (with an albedo of about 0.3 ) is flanked on both sides by bands of lower albedo (0.15) due to debris. The lateral variation in ice albedo appears to exceed the altitudinal variation in the ice albedo. From the results, we cannot conclude that the ice albedo shows a dependence on altitude. This has also been demonstrated by Brock et al. (2000) for the Haut Glacier d'Arolla (Switzerland) and Greuell et al. (1997) for the Pasterze (Austria), but for Hintereisferner, Koelemeijer et al. (1993) found the ice albedo increasing with elevation.

During the summer, the satellite-derived albedos of the glacier ice rise with about 0.06 , which is most likely associated with rainfall washing away debris. Albedo measurements made on the glacier during 1996 to 2000 and precipitation data from a weather station near Morteratschgletscher reveal 
that the daily mean albedo increases on $83 \%$ of all summer days with more than $5 \mathrm{~mm}$ of rainfall.

Concerning the modelling of the albedo within energy- and massbalance models, we conclude that for Morteratschgletscher, the glacier ice albedo should not be parameterised as function of altitude. We also found that the variation in the ice albedo is mainly caused by bands with high debris concentrations flanking a band of clean ice in the middle of the glacier tongue. However, if we were to prescribe lower ice albedos for these areas within the mass-balance model, we would possibly need to include the insulating effect of the debris cover to prevent overestimation of the melt rate. Lastly, we could prescribe a lower ice albedo for crevassed areas and make the ice albedo a function of summer rainfall. As the changes in albedo due to these effects are small, we think that they have little impact on the mass-balance calculation. In a future project, we will use the satellitederived albedos of this study as input for an albedo scheme used in the mass-balance model of Morteratschgletscher (Chapter 4).

Acknowledgements - We would like to thank Wouter Knap and Carleen Reijmer for helping us with the albedo retrieval method and commenting on an earlier version of this paper. We are grateful to Angie Souren who corrected the English. We also thank two referees and Scientific Editor, H. Rott for their useful comments.

\section{REFERENCES}

Arnold, N.S.I., Willis, I.C., Sharp, M.J., Richards, K.S. and Lawson, W.J. 1996. A distributed surface energy-balance model for a small valley glacier, I, Development and testing for Haut Glacier d'Arolla, Valais, Switzerland. Journal of Glaciology, 42(140), 77-89.

Brock, B.W., Willis, I.C. and Sharp, M.J. 2000. Measurements and parameterization of albedo variations at Haut Glacier d'Arolla, Switzerland. Journal of Glaciology, 46(155), 675-688.

De Ruyter de Wildt, M.S., Oerlemans, J. and Björnsson, H. 2002. A method for monitoring glacier mass balance using satellite albedo measurements: application to Vatnajökull (Iceland). Journal of Glaciology, 48(161), 267-178.

Dozier, J. and Frew, J. 1990. Rapid calculation of terrain parameters for radiation modeling from digital elevation data. IEEE Transactions on Geosciences and Remote Sensing, 28(5), 963-969.

Greuell, W., Knap, W.H. and Smeets, P.C. 1997. Elevational changes in meteorological variables along a midlatitude glacier during summer. Journal of Geophysical Research, 102(D22), 25,941-25,954.

Greuell, W. and De Ruyter de Wildt, M.S. 1999. Anisotropic reflection by melting glacier ice: measurements and parameterizations in Landsat TM bands 2 and 4 . Remote Sensing of Environment, 70, 265-277. 
Greuell, W. 2000. Melt-water accumulation on the surface of the Greenland ice sheet: effect on albedo and mass balance. Geografiska Annaler, 82A(4), 489-498.

Klok, E.J. and Oerlemans, J. 2002. Model study of the spatial distribution of the energy and mass balance of Morteratschgletscher, Switzerland. Journal of Glaciology, 48(163), 505-518.

Knap, W.H. and Oerlemans, J. 1996. The surface albedo of the Greenland ice sheet: satellite-derived an in situ measurements in the Søndre Strømfjord area during the 1991 melt season. Journal of Glaciology, 42(141), 364-374.

Knap, W.H., Reijmer, C.H. and Oerlemans, J. 1999a. Narrowband to broadband conversion of Landsat-TM glacier albedos. International Journal of Remote Sensing, 20(10), 2091-2110.

Knap, W.H., Brock, B.W., Oerlemans, J. and Willis, I.C. 1999b. Comparison of Landsat-TM derived and ground-based albedo of Haut Glacier d'Arolla. International Journal of Remote Sensing, 20(17), 3293-3310.

Koelemeijer, R., Oerlemans, J. and Tjemkes, S. 1993. Surface reflectance of Hintereisferner, Austria, from Landsat 5 TM imagery. Annals of Glaciology, 17, 17-21.

Koks, M. 2001. Anisotropic reflection of radiation by melting snow, Landsat TM bands 2 and 4 (MSc thesis, IMAU, University of Utrecht, The Netherlands, V01-04).

Markham, B.L. and Barker, J.L. 1985. Spectral characterization of the LANDSAT Thematic Mapper sensors. International Journal of Remote Sensing, 6(5), 697-716.

NASA (National Aeronautics and Space Administration), 2001. Landsat-7 science data users' handbook. Greenbelt, M.D., U.S., National Aeronautics and Space Administration, Goddard Space Flight Center.

(http:/ /ltpwww.gsfc.nasa.gov/IAS/handbook/handbook_toc.html)

Oerlemans, J. 1992. Climate sensitivity of glaciers in southern Norway: application of an energy-balance model to Nigardsbreen, Hellstugubreen and Alfotbreen. Journal of Glaciology, 38(129), 223-232.

Oerlemans, J. and Knap, W.H. 1998. A 1 year record of global radiation and albedo in the ablation zone of the Morteratschgletscher, Switzerland. Journal of Glaciology, 44(147), 231-238.

Paterson, W.S.B. 1994. The physics of glaciers. Pergamon Press, 3rd edition, 480 pp.

Proy, C., Tanré, D. and Deschamps, P.Y. 1989. Evaluation of topographic effects in remotely sensed data. Remote Sensing of Environment, 30, 21-32.

Reijmer, C.H., Knap, W.H. and Oerlemans J. 1999. The surface albedo of the Vatnajökull ice cap, Iceland: A comparison between satellite-derived and ground-based measurements. Boundary-Layer Meteorology, 92(1), 125-144.

Richter, R. 1998. Correction of satellite imagery over mountainous terrain. Applied Optics, 37(18), 4004-4015.

Sandmeier, S. and Itten, K.I. 1997. A physically-based model to correct atmospheric and illumination effects in optical satellite data of rugged terrain. IEEE Transactions on Geosciences and Remote Sensing, 35(3), 708-717.

Slingo, A. and Schrecker, H.M. 1982. On the shortwave radiation properties of stratiform water clouds. Quarterly Journal of the Royal Meteorological Society, 108, $407-426$.

Stroeve, J., Nolin, A. and Steffen, K. 1997. Comparison of AVHRR-derived and in situ surface albedo over the Greenland ice sheet. Remote Sensing of Environment, 62, 262-276. 
Teillet, P.M., Barker, J.L., Markham, B.L., Irish, R.R., Fedosejevs, G. and Storey, J.C., 2001. Radiometric cross-calibration of the Landsat-7 ETM+ and Landsat-5 TM sensors based on tandem data sets. Remote Sensing of Environment, 78, 39-54.

Vermote, E.F., Tanré, D., Deuzé, J.L., Herman, M. and Morcrette, J.J. 1997. Second simulation of the satellite signal in the solar spectrum, 6S: An overview. IEEE Transactions on Geosciences and Remote Sensing, 35(3), 675-686.

Warren, S.G., Brandt, R.E. and O'Rawe Hinton, P. 1998. Effect of surface roughness on bidirectional reflectance of Antarctic snow. Journal of Geophysical Research, 103(E11), 25,789-25,805.

Xin, L., Koike, T. and Guodong, C. 2002. Retrieval of snow reflectance from Landsat data in rugged terrain. Annals of Glaciology, 34, 31-37. 


\title{
2 MODEL STUDY OF THE SPATIAL DISTRIBUTION OF THE ENERGY AND MASS BALANCE OF MORTERATSCHGLETSCHER, SWITZERLAND*
}

\begin{abstract}
To investigate the spatial distribution of the energy- and mass-balance fluxes of a glacier, a two-dimensional mass-balance model was developed and applied to Morteratschgletscher. The model is driven by meteorological input from four synoptic weather stations located in the vicinity of Morteratschgletscher. The model results were compared to observations made on the glacier. The calculated mean specific mass balance of 1999 is -0.47 $\mathrm{m}$ w.e. and $0.23 \mathrm{~m}$ w.e. for 2000 . Net shortwave radiation shows a minimum at around $3350 \mathrm{~m}$ a.s.1., due to the effects of shading, slope, aspect, reflection from the slopes, and obstruction of the sky. Ignoring these effects results in an increase of $37 \%$ in the annual incoming shortwave radiation on the glacier, causing a decrease in the mass balance of $0.34 \mathrm{~m}$ w.e. A $1{ }^{\circ} \mathrm{C}$ change in the air temperature results in a shift in the mean specific mass balance of $0.67 \mathrm{~m}$ w.e., while altering the precipitation by $10 \%$ causes a change of $0.17 \mathrm{~m}$ w.e.
\end{abstract}

"Based on: Klok, E.J. and Oerlemans, J. 2002. Model study of the spatial distribution of the energy and mass balance of Morteratschgletscher, Switzerland. Journal of Glaciology, 48(163), 505-518. 


\subsection{INTRODUCTION}

Many different models have been developed to study the relationship between climate and glaciers. These models are either ablation or massbalance models and range from zero-dimensional to two-dimensional.

The difference between ablation and mass-balance models is that ablation models only cover the ablation period. They are also used to calculate the runoff from a glacier or ice cap. For instance, Braithwaite (1995) and Hock (1999) estimated the runoff from respectively Greenland and Storglaciären, by using a temperature index method to calculate the melt rate. The melt rate was calculated with an energy-balance model by, for example, Escher-Vetter (2000) for Vernagtferner, Hock and Noetzli (1997) for Storglaciären, and Arnold et al. (1996) for Haut Glacier d'Arolla.

Mass-balance models calculate the net result of snow accumulation and melt on a glacier for one or more years. Among the simplest massbalance models are methods that regress mean summer temperature and snowfall on the mass balance (e.g. Greuell, 1992; Wallinga and Van de Wal, 1998). Schneeberger et al. (2001) used the temperature index method of Hock (1999) and an accumulation scheme to derive the mass balance of Storglaciären. As far as we know, the mass balance of an alpine glacier and its spatial distribution has not yet been studied using a two-dimensional mass-balance model that is based on the surface energy balance of a glacier.

The purpose of this research is to study the spatial distribution of the energy and mass-balance fluxes of a glacier. For this reason, we developed a two-dimensional mass-balance model based on the surface energy balance. The effects of shading and topography on the mass balance are investigated with this model. The results can be used to determine the sensitivity of the mass balance to a climate change.

We applied the model to Morteratschgletscher in Switzerland (see Figure 3.1), for several reasons. Firstly, many synoptic weather stations are located in the vicinity of Morteratschgletscher. Secondly, the Institute for Marine and Atmospheric Research, Utrecht (IMAU), has been operating automatic weather stations on Morteratschgletscher. These year-round data sets are useful to evaluate the model performance and to optimise the parameterisation schemes of the mass-balance model. Finally, Morteratschgletscher is very suitable to study the effects of shading and topography on the mass balance because of its location between high mountains.

The model is driven by meteorological data from several synoptic weather stations located near the glacier. We could also have used the data from the automatic weather stations located on Morteratschgletscher. However, an important difference between these two types of data is that 
instruments on a glacier measure the microclimate of the glacier boundary layer, whereas the synoptic weather stations register an atmosphere which is not influenced by the glacier boundary layer, but depict the microclimate of an alpine area. In order to study the effect of climate changes, a massbalance model should be able to generate a mass-balance field from data that are not influenced by the glacier. Therefore, we attempted to relate the glacier mass balance to meteorological variables measured at synoptic weather stations. This also makes it possible to reconstruct the mass balance over a longer period of time. Another advantage of using data from
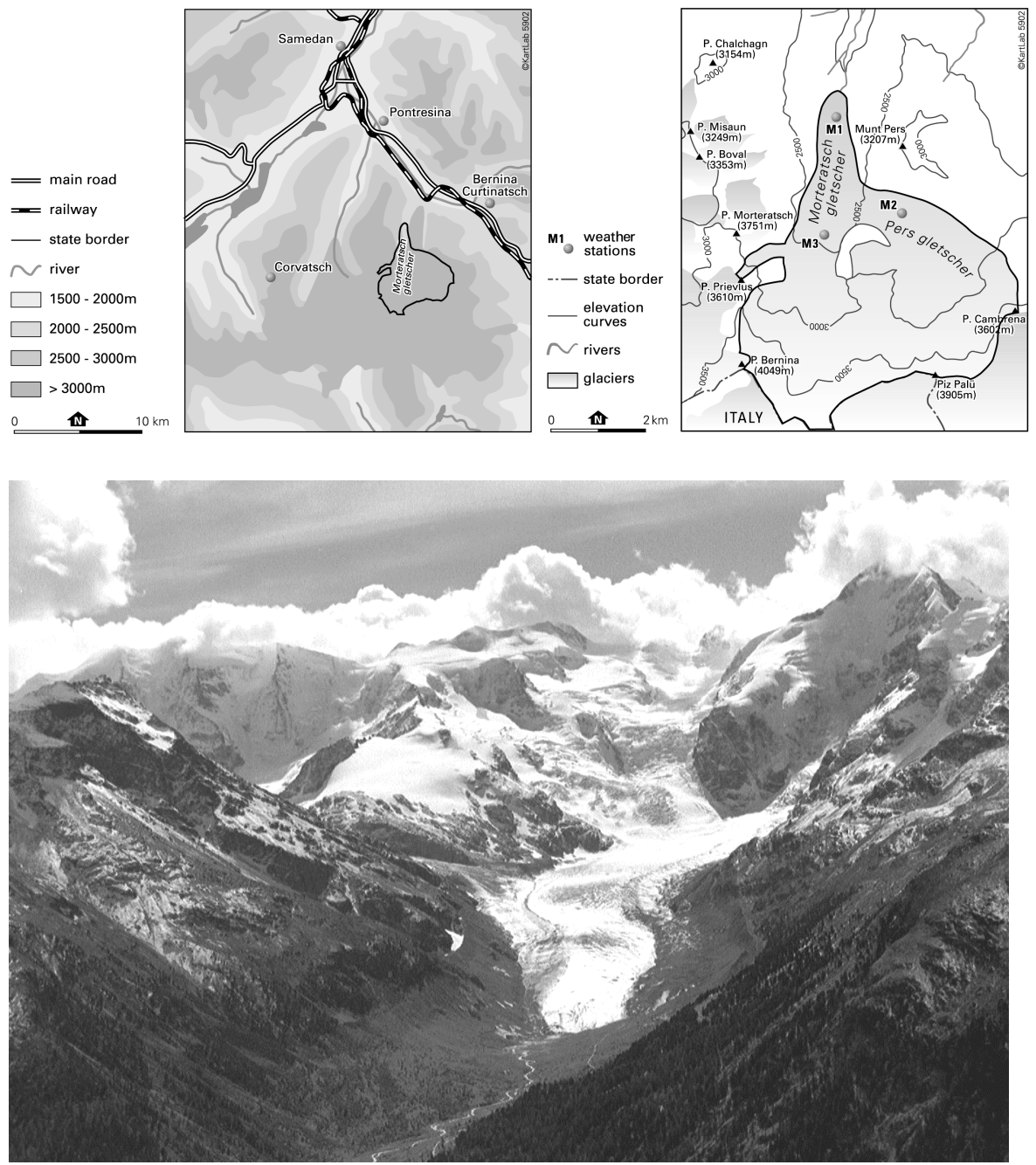

Figure 3.1: Morteratschgletscher. Top left: map of the area around Morteratschgletscher, showing the locations of the Meteo Schweiz synoptic weather stations. Top right: map of Morteratschgletscher, showing the IMAU automatic weather stations (M1, M2 and M3). Bottom: picture of the glacier tongue (2001). 
synoptic weather stations is that it facilitates the application of the model to a different glacier.

We simulated the energy fluxes and the mass balance of Morteratschgletscher for two years: 1999 and 2000. In this chapter, we describe the mass-balance model and compare model results with the measurements on the glacier. We also carry out a parameter sensitivity test. Furthermore, we examine the spatial distribution of the energy balance components and the mass balance of Morteratschgletscher and the effects of topography on the shortwave radiation and the mass balance. Finally, we perform a few simple mass-balance sensitivity tests in which air temperature and precipitation are varied.

\subsection{MORTERATSCHGLETSCHER}

The mass-balance model was tested for Morteratschgletscher (Figure $3.1)$ in southeast Switzerland $\left(46^{\circ} 24^{\prime} \mathrm{N}, 8^{\circ} 02^{\prime} \mathrm{E}\right)$. Its altitude ranges from 2000 to $4000 \mathrm{~m}$ a.s.l. and its area is about $17.15 \mathrm{~km}^{2}$. The glacier is currently $7 \mathrm{~km}$ long, but it has retreated about $2 \mathrm{~km}$ since 1878. The Persgletscher flows into Morteratschgletscher at a distance of $2 \mathrm{~km}$ from the snout of Morteratschgletscher. In this study, both glaciers are treated as one: Morteratschgletscher. The glacier is surrounded by high mountains of which the highest peak is $4048 \mathrm{~m}$ a.s.l. (Piz Bernina).

\subsection{THE DATA}

The model is based on the digital elevation model of 1996 from the Bundesamt für Landestopographie of Switzerland (resolution is $25 \mathrm{~m}$ ). Slope and aspect of each grid cell were computed from this digital elevation model by using four surrounding grid cells (Dozier and Frew, 1999).

Data from four synoptic stations of Meteo Schweiz served as input for the model (Figure 3.1): Samedan is located at an altitude of $1705 \mathrm{~m}$ a.s.l., Corvatsch at $3315 \mathrm{~m}$ a.s.l., Bernina-Curtinatsch at $2095 \mathrm{~m}$ a.s.l., and Pontresina at $1774 \mathrm{~m}$ a.s.l. From Samedan and Corvatsch, we used halfhourly values of air temperature $\left(T_{a}\right)$, relative humidity $(R H)$ air pressure $(p)$ and incoming shortwave radiation $\left(I_{\text {mens }}\right)$. The shortwave radiation measurements of Corvatsch were used to estimate cloud cover. In addition, we used daily precipitation data from the stations Bernina-Curtinatsch and Pontresina, and half-hourly precipitation rates of Samedan.

The model results were compared to data from three automatic weather stations located on the glacier operated by the IMAU: M1, M2 and M3 (Figure 3.1). M1 is located at an altitude of $2104 \mathrm{~m}$ a.s.l. and has been 
measuring since 1995. M2 (2700 m a.s.l.) and M3 (2500 m a.s.l.) were set up in the summer of 1999. At M1 and M2, a weather station stands freely on the ice surface. It measures air temperature, relative humidity, wind speed and wind direction, incoming and reflected shortwave radiation, and incoming and outgoing longwave radiation at a height of $3.5 \mathrm{~m}$. In winter, the height of the sensors is $3.5 \mathrm{~m}$ minus the depth of the snow pack. At all locations, a tripod with a sonic ranger is drilled into the ice. It measures the relative surface height, supplying information about snow accumulation and melt. Around each sonic ranger, three stakes are drilled to measure ice melt. The instruments of the three stations did not measure during the entire period because of technical problems. In the winter, snow temperatures were measured and density profiles were taken in snow pits. More information about the data of M1 can be found in Oerlemans and Knap (1998), Oerlemans (2000a) and Oerlemans and Klok (2002). Table 3.1 gives an overview of the data that we used in this study for model input and model evaluation.

Table 3.1: Overview of the data of the weather stations (see Figure 3.1) used in this study.

\begin{tabular}{|c|c|c|}
\hline Station & Measured variables & Used for \\
\hline M1 & $\begin{array}{l}\text { incoming shortwave radiation } \\
\text { reflected shortwave radiation } \\
\text { incoming longwave radiation } \\
\text { outgoing longwave radiation } \\
\text { snow accumulation } \\
\text { snow depth } \\
\text { ablation (stakes \& sonic ranger) }\end{array}$ & $\begin{array}{l}\text { model evaluation } \\
\text { model evaluation } \\
\text { model evaluation } \\
\text { model evaluation } \\
\text { model evaluation } \\
\text { model evaluation } \\
\text { model evaluation }\end{array}$ \\
\hline M2 & $\begin{array}{l}\text { snow accumulation } \\
\text { snow depth } \\
\text { ablation (stakes) }\end{array}$ & $\begin{array}{l}\text { model evaluation } \\
\text { model evaluation } \\
\text { model evaluation }\end{array}$ \\
\hline M3 & $\begin{array}{l}\text { snow accumulation } \\
\text { ablation (stakes) }\end{array}$ & $\begin{array}{l}\text { model evaluation } \\
\text { model evaluation }\end{array}$ \\
\hline Corvatsch & $\begin{array}{l}\text { air temperature } \\
\text { humidity } \\
\text { air pressure } \\
\text { incoming shortwave radiation }\end{array}$ & $\begin{array}{l}\text { model input } \\
\text { model input } \\
\text { model input } \\
\text { model input }\end{array}$ \\
\hline Samedan & $\begin{array}{l}\text { air temperature } \\
\text { humidity } \\
\text { air pressure } \\
\text { incoming shortwave radiation } \\
\text { precipitation }\end{array}$ & $\begin{array}{l}\text { model input } \\
\text { model input } \\
\text { model input } \\
\text { model input } \\
\text { model input }\end{array}$ \\
\hline Pontresina & precipitation & model input \\
\hline Bernina-Curtinatsch & precipitation & model input \\
\hline
\end{tabular}




\subsection{MODEL DESCRIPTION}

The main formula of the mass-balance model is the equation that describes the specific mass balance, $M\left(\mathrm{~kg} \mathrm{~m}^{-2}\right)$ :

$$
M=\int\left\{\frac{Q_{m}}{L_{m}}+P+\frac{Q_{L}}{L_{s}}\right\} d t
$$

$Q_{m}$ is the melt energy involved in melting, $P$ is the snow accumulation and $Q_{L}$ represents the mass exchange due to sublimation. $L_{m}\left(3.3410^{5} \mathrm{~J} \mathrm{~kg}^{-1}\right)$ is the latent heat of melting and $L_{s}\left(2.8310^{6} \mathrm{~J} \mathrm{~kg}^{-1}\right)$ is the latent heat of sublimation.

$Q_{m}$ was calculated from the surface energy flux $(F)$, which is the energy flux from the atmosphere to the glacier:

$$
F=S_{\text {in }}-S_{\text {out }}+L_{\text {in }}-L_{\text {out }}+Q_{H}+Q_{L}=Q_{m}+G
$$

$S_{\text {in }}$ and $S_{\text {out }}$ are incoming and reflected solar radiation, $L_{\text {in }}$ and $L_{\text {out }}$ are incoming and outgoing longwave radiation, and $Q_{H}$ and $Q_{L}$ are the sensible and latent heat fluxes. The latter two are positive when directed towards the surface. The heat flux supplied by rain was neglected. The surface energy flux supplies energy for melting $\left(Q_{m}\right)$ and for the glacier heat flux $(G)$, which implies the warming or cooling of the snow or ice pack. Melting occurs when the surface temperature is at the melting point and the surface energy flux is positive. In that case, the glacier heat flux is is zero.

For each 30-minute period, the model calculated all energy and mass fluxes over the glacier. The air temperature $\left(T_{a}\right)$, the relative humidity $(R H)$ and the air pressure $(p)$ of each grid cell were calculated from the data of Corvatsch and Samedan. Air temperature and relative humidity were interpolated linearly with height to obtain values for each grid cell and air pressure was interpolated exponentially with height. In this section, we describe how the fluxes of Equations (3.1) and (3.2) were computed.

\subsubsection{INCOMING SOLAR RADIATION}

The calculation of incoming solar radiation is the most comprehensive part of the model. Incoming shortwave radiation without corrections for shading, angle of incidence, reflection and obstruction of the sky by the surrounding slope, I, was calculated from:

$$
I=I_{0} \cos (z) T_{R} T_{g} T_{w} T_{a s} T_{c l}
$$


$I_{0}$ is the flux at the top of the atmosphere on a surface normal to the incident radiation and $z$ is the solar zenith angle (Iqbal, 1983). $T_{R}$ and $T_{g}$ are transmission coefficients for Rayleigh scattering and gas absorption, $T_{w}$ accounts for water vapour absorption, $T_{a s}$ is the transmission coefficient for aerosol attenuation and $T_{c l}$ is a cloud factor. $T_{R}$ and $T_{g}$ depend on air pressure and optical air mass, calculated using expressions described in Meyers and Dale (1983). $T_{w}$ was also calculated after Meyers and Dale (1983). It depends on the total amount of precipitable water and was determined from the mixing ratio by using an expression of Smith (1966). $T_{a s}$ is calculated from a simple expression after Houghton (1954):

$$
T_{a s}=k^{m}
$$

where $m$ is the optical air mass and $k$ an empirical constant. $k$ was derived by fitting modelled to measured clear-sky conditions of Corvatsch and Samedan for the year 1999, following Greuell et al. (1997). Energy gained by multiple reflection between the atmosphere and surface was taken into account for the tuning of $k$ and only summer days were used. The surface albedo of Corvatsch was assumed to be 0.2 during this period because the station is located on the roof of a building, and the surface albedo of Samedan 0.25 because it is located on grass. A value of $k$ of 0.96 was found for Corvatsch and 0.92 for Samedan. The difference is due to the difference in altitude of the stations. Gueymard (1993) estimated a value of 0.94 for Weissflujoch, which is located at an altitude of $2667 \mathrm{~m}$, about $50 \mathrm{~km}$ north of Morteratschgletscher. A value of $k$ for each grid cell was derived by linear interpolation with height between the $k$ values of Corvatsch and Samedan. The cloud factor is independent of height and was determined from incoming shortwave radiation measured at Corvatsch $\left(I_{\text {meas }}\right)$, following:

$$
T_{c l}=\frac{I_{\text {meas }}}{I_{c s}}
$$

where $I_{c s}$ is the calculated clear-sky radiation for Corvatsch using Equation (3.3) with $T_{c l}=1$.

We determined topographic shading for each grid cell using a procedure after Dozier and Frew (1990). Then, we split the shortwave radiation in a diffuse and direct part. Shaded grid cells only receive diffuse radiation. The direct $\left(f_{\text {dir }}\right)$ and diffuse $\left(f_{\text {dif }}\right)$ fraction of the shortwave radiation was computed from a relationship suggested by Oerlemans (1992):

$$
f_{\text {dir }}=0.2+0.65(1-n)
$$




$$
f_{\text {dif }}=1-f_{\text {dir }}=0.8-0.65(1-n)
$$

where $n$ is the fractional cloud cover, which was computed from $T_{c l}$ by using an equation based on cloud observations on the Pasterze, Austria, suggested by Greuell et al. (1997):

$$
T_{c l}=1.000-0.233 n-0.415 n^{2}
$$

During the night, $n$ was estimated from linear interpolation with time between the fractional cloud cover before sunset and after sunrise. The surrounding topography reduces the amount of incoming diffuse radiation. Therefore, we multiplied diffuse radiation by a sky view factor, $V_{s k y}$ as defined by Dozier and Frew (1990). We corrected the direct part of the shortwave radiation for the angle of incidence, by using equations from Iqbal (1983). Finally, the amount of reflected radiation from the surrounding terrain was added to estimate the total incoming solar radiation impinging on a grid cell. We estimated the reflected radiation, $I_{\text {refl }}$ from:

$$
I_{\text {refl }}=V_{\text {ter }}\left(f_{i c e} \alpha_{i c e}+\left(1-f_{i c e}\right) \alpha_{t e r}\right) I_{\text {mean }}
$$

where $V_{\text {ter }}$ is the terrain view factor calculated after Dozier and Frew $(1990), f_{\text {ice }}$ is the fraction of the surrounding terrain covered by the glacier, $\alpha_{i c e}$ and $\alpha_{\text {ter }}$ are the mean albedo of the glacier and the surrounding terrain respectively, and $I_{\text {mean }}$ is the mean shortwave radiation over the glacier after correction for shading and angle of incidence. The terrain albedo was assumed to be 0.5 when the calculated snow depth on the tongue exceeded zero or else the terrain albedo is 0.1 . We calculated $f_{\text {ice }}$ for each grid cell as the percentage of the grid cells that was covered by the glacier and visible from a grid cell. Shading, zenith angle and angle of incidence were calculated for every 10 minutes, from which half-hourly means were derived.

\subsubsection{REFLECTED SHORTWAVE RADIATION}

We calculated the albedo of each grid cell by using the method of Oerlemans and Knap (1998) to determine the reflected shortwave radiation. They optimised this method with data from M1. The glacier albedo, $\alpha^{(i)}$, depends on the snow depth:

$$
\alpha^{(i)}=\alpha_{\text {snow }}{ }^{(i)}+\left(\alpha_{\text {ice }}-\alpha_{\text {snow }}{ }^{(i)}\right) \exp \left(\frac{-d}{d^{*}}\right)
$$


where $\alpha^{(i)}{ }_{\text {snow }}$ is the albedo of snow, $\alpha_{i c e}$ the albedo of ice (0.34), $d$ is the snow depth (mm w.e.) and $d^{*}$ is the characteristic scale for snow depth $(11 \mathrm{~mm}$ w.e.). We estimated $d^{*}$ by multiplying the depth scale found by Oerlemans and Knap (1998) by a snow density of $350 \mathrm{~kg} \mathrm{~m}^{-3}$. The snow albedo depends on the time since the previous snowfall event following:

$$
\alpha_{\text {snow }}^{(i)}=\alpha_{\text {firn }}+\left(\alpha_{\text {frsnow }}-\alpha_{\text {firn }}\right) \exp \left(\frac{s-i}{t *}\right)
$$

where $\alpha_{\text {firn }}$ is the albedo of firn (0.53), $\alpha_{\text {frsnow }}$ is the fresh snow albedo (0.9), $s$ is the time since the previous snowfall event (in days), $i$ is the actual time (in days) and $t^{*}$ is a time scale (21.9 days). The values for the firn and ice albedo and the time scale are from Oerlemans and Knap (1998).

\subsubsection{LONGWAVE RADIATION}

The incoming longwave radiation, $L_{i n}$ is computed from:

$$
L_{i n}=\varepsilon \sigma T_{a}^{4}
$$

where $\varepsilon$ is the emissivity of the sky and $\sigma$ the Stefan-Boltzman constant. The emissivity of the sky varies with cloud cover and was calculated following a parameterisation found by Konzelmann et al. (1994) for Greenland:

$$
\varepsilon=\varepsilon_{c s}\left(1-n^{p}\right)+\varepsilon_{c l} n^{p}
$$

where $\varepsilon_{c s}$ is the clear-sky emissivity, $\varepsilon_{c l}$ is the cloud emissivity and $p$ is an exponent. The clear-sky emissivity depends on the greenhouse gases concentration, the vapour pressure and the air temperature:

$$
\varepsilon_{c s}=0.23+b\left(\frac{e_{a}}{T_{a}}\right)^{1 / 8}
$$

where $e_{a}$ is the water vapour pressure. We neglected longwave radiation emitted by the surrounding slopes and obstruction of longwave radiation from the sky by the surrounding slopes. Greuell et al. (1997) applied this method to observations made on the Pasterze and found $p$ to be 2. We took this value and determined the parameters $b$ and $\varepsilon_{c l}$ by fitting $L_{i n}$ to measured longwave radiation at M1 of 1999. We found a value of 0.433 for $b$ and estimated $\varepsilon_{c l}$ at 0.984 . The best parameter values of Greuell et al. (1997), after correction of the small amount of longwave radiation coming from the 
surrounding slopes, are 0.976 for $\varepsilon_{c l}, 0.475$ for $b$ at $2310 \mathrm{~m}$ a.s.l. and 0.407 for $b$ at 3225 m a.s.l. A comparison of the parameter values of Greuell et al. (1997) with those found in this study is not truly justified because they used 2-m temperatures along the glacier measured in summer for the parameterisation of $L_{i n}$, while the present study uses air temperatures of an entire year from synoptic weather stations.

Assuming that snow and ice emit as a black body in the infrared, the outgoing longwave radiation, $L_{\text {out }}$ was determined from:

$$
L_{\text {out }}=\sigma T_{\text {surf }}^{4}
$$

where $T_{\text {surf }}$ is the surface temperature, computed from the surface energy flux (see Section 3.4.5).

\subsubsection{TURBULENT FLUXES}

The problem with calculating the turbulent fluxes above a glacier surface from data of synoptic weather stations located in the vicinity of the glacier is that these temperatures, vapour pressures and wind speeds differ from those in the glacier boundary layer, where the glacier wind affects them. Methods to estimate the turbulent fluxes should therefore relate the conditions of the atmosphere outside the glacier boundary layer to the conditions inside the glacier boundary layer. We used equations of Oerlemans and Grisogono (2002) to calculate the latent and sensible heat fluxes:

$$
\begin{aligned}
& Q_{H}=-\rho c_{p} \frac{C_{k a t}+C_{b}}{2}\left(T_{a}-T_{\text {surf }}\right) \\
& Q_{L}=-0.622 \rho L_{v / s} \frac{C_{k a t}+C_{b}}{2}\left(\frac{e_{a}-e_{\text {surf }}}{p}\right)
\end{aligned}
$$

where $\rho$ is the air density, $c_{p}$ is the specific heat of dry air, $L_{v / s}$ is the latent heat of vapourisation $\left(L_{v}=2.510^{6} \mathrm{~J} \mathrm{~kg}^{-1}\right)$ or, when the surface temperature is below the melting point, of sublimation $L_{s}$. $e_{\text {surf }}$ is the saturated vapour pressure above ice of the surface temperature and $C_{k a t}$ is a katabatic turbulent exchange coefficient. In addition to the katabatic forcing, the large-scale wind field also generates turbulence, which is accounted for by the background turbulent exchange coefficient, $C_{b}$. $C_{k a t}$ was estimated from (Oerlemans and Grisogono, 2002): 


$$
C_{k a t}=-k\left(T_{a}-T_{\text {surf }}\right)\left(\frac{g}{T_{0} \gamma \operatorname{Pr}}\right)^{1 / 2}
$$

$k$ is an empirical constant, $g$ is the gravity, $T_{0}$ is a reference temperature $(273.15 \mathrm{~K})$ and $\gamma$ is the background potential temperature lapse rate, and $\mathrm{Pr}$ is the eddy Prandtl number. We calculated $\gamma$ from potential air temperature of Samedan and Corvatsch. On very warm days, $\gamma$ sometimes becomes negative. Consequently, $C_{k a t}$ cannot be calculated. Therefore, a lower limit of $0.0015 \mathrm{~K} \mathrm{~m}^{-1}$ was defined for the potential temperature lapse rate. Values for $\mathrm{Pr}$ and $k$ were taken from Oerlemans and Grisogono (2002), estimated from extensive eddy correlation measurements on the Pasterze ( $P r=5$ and $k=0.0004$ ). The mean value of $C_{k a t}$ for 1999 is $0.0031 . C_{k a t}$ is largest on warm days because then the temperature difference between the air and the glacier surface is large and the potential temperature gradient often small. On these days, glacier winds develop and generate turbulence. $C_{b}$ was optimised in such a way that calculated melt was in agreement with observed melt at M1 for 1999, resulting in a value of 0.0037 .

\subsubsection{GLACIER HEAT FLUX AND SURFACE TEMPERATURE}

We assumed that the glacier heat flux equals the surface energy flux if the surface temperature is below the melting point or if the surface heat flux is negative. The change in the surface temperature was estimated from a simple two-layer subsurface model. We assumed that the heat flux between two layers is proportional to the temperature difference, but discounted refreezing of melt water. The change in temperature of the surface layer ( $\left.T_{\text {surf }}\right)$ and the second layer $\left(T_{2}\right)$ was calculated from:

$$
\begin{aligned}
& \frac{\Delta T_{\text {surf }}}{\Delta t}=\kappa \frac{\left(T_{2}-T_{\text {surf }}\right) / \Delta z}{d_{\text {surf }}}+\frac{G}{c \rho d_{\text {surf }}} \\
& \frac{\Delta T_{2}}{\Delta t}=\kappa \frac{\left(T_{3}-T_{2}\right) / \Delta z-\left(T_{2}-T_{\text {surf }}\right) / \Delta z}{d_{2}}
\end{aligned}
$$

where $c$ is the specific heat capacity $\left(2097 \mathrm{~J} \mathrm{~kg}^{-1} \mathrm{~K}^{-1}\right), \kappa$ is the thermal diffusivity and $\rho$ the density of the surface layer layer. The glacier heat flux $(G)$ is only added to the surface layer. The depths of the surface layer $\left(d_{\text {surf }}=\right.$ $0.22 \mathrm{~m})$ and the second layer $\left(d_{2}=2.78 \mathrm{~m}\right)$ approximate the depths where respectively the daily and yearly temperature amplitudes reach $5 \%$ of their surface value. The temperature of the lowest boundary $\left(T_{3}\right)$ is fixed in time: 
$273 \mathrm{~K}$ at the glacier tongue, decreasing $5 \mathrm{~K}$ per $1000 \mathrm{~m}$ of altitude. A weighted average between snow depth and ice depth of the first $0.22 \mathrm{~m}$ determines the density of the surface layer. If the snow depth exceeds 0.22 $\mathrm{m}$, the density equals snow density $\left(350 \mathrm{~kg} \mathrm{~m}^{-3}\right)$. A similar approach is used to determine the thermal diffusivity of the surface layer. The diffusivity of ice is $1.1610^{-6} \mathrm{~m}^{2} \mathrm{~s}^{-1}$ and the diffusivity of snow $0.410^{-6} \mathrm{~m}^{2} \mathrm{~s}^{-1}$.

\subsubsection{SNOW ACCUMULATION}

Snow accumulation was calculated from the amount of snowfall. The redistribution of snow by wind drift or avalanching was not taken into account. Schwarb (2000) calculated a mean precipitation gradient $\left(\gamma_{p}\right)$ of about $0.4 \mathrm{~mm} \mathrm{~m}^{-1}$ for the Morteratsch area by using a complex interpolation scheme. We used this gradient and the mean precipitation between Pontresina and Bernina-Curtinatsch to calculate precipitation rates for each grid cell. Half-hourly precipitation rates at Samedan were used to transform daily precipitation amounts of Pontresina and Bernina-Curtinatsch into half-hourly precipitation rates, assuming that the precipitation distribution over the day is the same at these locations. Snowfall was distinguished from liquid precipitation by using a threshold temperature $\left(T_{\text {solid/liquid }}\right)$ of $1.5^{\circ} \mathrm{C}$.

\subsubsection{SNOW DEPTH}

Each time step, snow depth was calculated from snow accumulation, sublimation and melt and the snow depth of the previous time step. The snow depth at the beginning of 1999 was found by running the model for two years. Then, this distribution in snow depth over the glacier was multiplied by a factor, so that the modelled snow depth at M1 matched the snow depths estimated from snow profiles measured in February and April 1999.

\subsection{PARAMETER SENSITIVITY}

The model contains many parameters, of which some were taken from the literature $\left(\alpha_{\text {firn }}, \alpha_{\text {frsnow }}, t^{*}, \alpha_{i c e} p\right)$ et al. were estimated from the data measured on Morteratschgletscher $\left(b, \varepsilon_{c l}\right)$ or from the synoptic weather stations $(k)$. The only parameter that was used to tune the model is the backgroud turbulent exchange coefficient $\left(C_{b}\right)$.

We changed some model parameters to investigate the sensitivity of the model. Table 3.2 shows the results. A change in the katabatic turbulent exchange coefficient or the precipitation gradient influences the mass balance of Morteratschgletscher significantly. However, a decrease in the ice albedo or a change in the threshold temperature for liquid and solid precipitation affects the mass balance more seriously. Lowering the ice 
albedo by 0.08 results in an increase in net shortwave radiation of $6 \%$. A decrease of $0.5 \mathrm{~K}$ in the threshold temperature implies $5 \%$ less snowfall. Decreasing the temperature of the third ice layer by $5 \mathrm{~K}$ does not affect the mass balance significantly, but halving the surface layer depth results in warmer surface temperatures and more ablation.

We also varied cloud cover because the parameterisation scheme used to derive cloud cover is assumed to be not very accurate. We compared fractional cloud cover derived from incoming shortwave radiation at Corvatsch with cloud cover derived from radiation measurements at M1 using the method described in Section 3.4.1. We found that for 1999, the calculated fractional cloud cover at Corvatsch is 0.03 smaller than at M1. The residual standard deviation is 0.35 . Therefore, we determined the effect of a change of 0.2 in the fractional cloud cover on the modelled mass balance (see Table 3.2). Decreasing the fractional cloud cover does not influence the mass balance substantially because the decrease in longwave radiation is roughly compensated by an increase in shortwave radiation. However, increasing cloud cover leads to significantly more ablation. This is due to the increase in incoming longwave radiation, while shortwave radiation does not change much, which can be explained by the non-linear effect of cloud cover on shortwave radiation (Equation (3.8)).

Table 3.2: Change in the mean specific mass balance of 1999 with respect to changes in some parameters.

\begin{tabular}{llll}
\hline Parameter & Description & Forcing & $\Delta B(m$ w.e. $)$ \\
\hline$C_{b}$ & $\begin{array}{l}\text { background turbulent } \\
\text { exchange coefficient }\end{array}$ & +0.0005 & +0.04 \\
& precipitation gradient & $-0.05 \mathrm{~mm} \mathrm{~m}^{-1}$ & -0.07 \\
$\gamma_{p}$ & threshold temperature for & $-0.5 \mathrm{~K}$ & -0.14 \\
$T_{\text {solidliquid }}$ & liquid or solid precipitation & & \\
\multirow{2}{*}{$\alpha_{i c e}$} & ice albedo & -0.04 & -0.07 \\
& & -0.08 & -0.15 \\
$T_{3}$ & temperature of third ice layer & $-5 \mathrm{~K}$ & +0.01 \\
$z_{1}$ & depth of surface layer & $-0.11 \mathrm{~m}$ & -0.11 \\
$n$ & fractional cloud cover & -0.2 & $<+0.01$ \\
& & +0.2 & -0.18 \\
\hline
\end{tabular}

\subsection{RESULTS}

\subsubsection{COMPARISON WITH OBSERVATIONS AT M1, M2 AND M3}

It is important to compare model results with measurements to see if the model is capable of reproducing correct mass and energy fluxes. To this end, observations of short- and longwave radiation at M1 and snow 
accumulation, snow depth, ice melt and mass-balance measurements at M1, M2 and M3 were used.

In Figure 3.2, daily mean incoming and reflected shortwave and incoming and outgoing longwave radiation measurements at M1 in 1999 and 2000 are compared to model simulations for the grid cell in which M1 is located. The annual mean measured incoming shortwave radiation exceeds the modelled values by $2.9 \mathrm{~W} \mathrm{~m}^{-2}$ and the residual standard deviation is $22.2 \mathrm{~W} \mathrm{~m}^{-2}$. Although a correction is made for the tilt of the mast, shortwave radiation is somewhat underestimated. Annual mean reflected shortwave radiation is overestimated by $2.6 \mathrm{~W} \mathrm{~m}^{-2}$. The residual standard deviation is $22.9 \mathrm{~W} \mathrm{~m}^{-2}$. This overestimation can be explained by a too high value for $d^{*}$, according to the late decrease in albedo in spring compared to the measurements (Figure 3.3). Furthermore, it could be due to the value of the
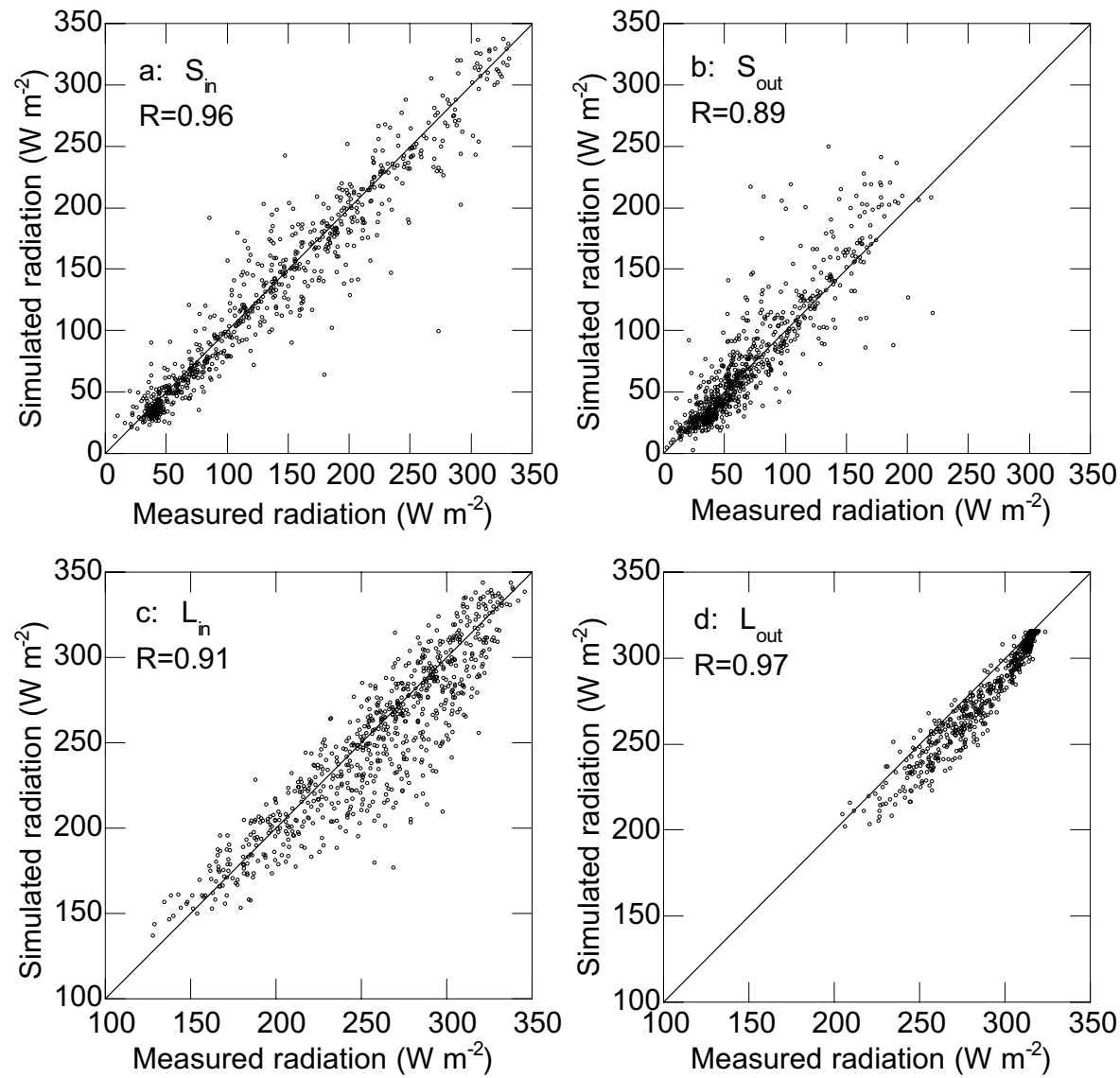

Figure 3.2: Comparison of daily modelled incoming (a) and reflected (b) solar radiation and incoming (c) and outgoing (d) longwave radiation for the grid cell in which M1 is located with measurements at M1 for 1999 and 2000. The solid line is the 1:1 line and $R$ is the correlation coefficient. 


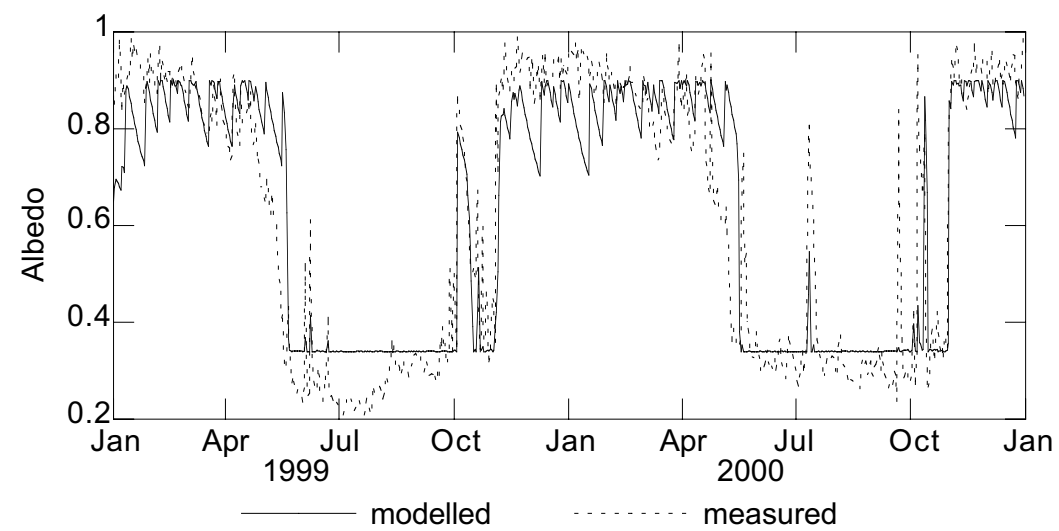

Figure 3.3: Measured albedo at M1 and modelled albedo for the grid cell in which M1 is located for 1999 and 2000.

ice albedo used in the model (0.34), which is often larger than the measured albedo at M1 (Figure 3.3). Since the debris concentration is largest on the glacier tongue, thus around M1, the mean ice albedo of the glacier will be larger than at M1. Therefore, an ice albedo value of 0.34 is probably a good representation of the mean ice albedo of the glacier.

Annual mean incoming longwave radiation is underestimated by 6.8 $\mathrm{W} \mathrm{m} \mathrm{m}^{-2}$. Its residual standard deviation is $21.5 \mathrm{~W} \mathrm{~m}^{-2}$. Also, annual mean outgoing longwave radiation is underestimated, by $7.7 \mathrm{~W} \mathrm{~m}^{-2}$, but its residual standard deviation is $11.0 \mathrm{~W} \mathrm{~m}^{-2}$. This implies that daily modelled surface temperatures were underestimated, with $1.8 \mathrm{~K}$, compared to surface temperatures at M1 estimated from measured outgoing longwave radiation.

Table 3.3 compares simulated and observed snow accumulation. The observed accumulation was derived from the sonic rangers. First, we calculated daily mean relative surface heights. Then, we determined daily accumulation as the height difference between two days. We used a snow density of $180 \mathrm{~kg} \mathrm{~m}^{-3}$ to convert snow depths into water equivalent.

Table 3.4 compares simulated with observed snow depths derived from snow profiles. Clearly, the model results do not perfectly match the observations. This is to be expected because the model does not capture the spatial variation in precipitation well: precipitation data from only two stations in the valley were used to calculate snowfall over the glacier. On the other hand, falling snow may be subject to snow drift and avalanching. Furthermore, one threshold temperature was used to distinguish solid from liquid precipitation, which may have been an oversimplification. Snow accumulation is complicated to simulate and we would need more measurements at different altitudes and locations in the Morteratsch area for accurate modelling of snow accumulation. It is also likely that errors in the modelled melt rates contribute to the differences. 
Table 3.3: Observed and simulated snow accumulation (cm w.e.) over different periods and at different locations (see Figure 3.1).

\begin{tabular}{llll}
\hline Station & Days, year & Observed & Simulated \\
\hline M1 & $1-365,1999$ & 52 & 44 \\
M2 & $211-365,1999$ & 32 & 38 \\
M3 & $211-365,1999$ & 29 & 22 \\
M1 & $211-365,1999$ & 13 & 13 \\
M1 & $1-366,2000$ & 63 & 78 \\
M2 & $1-94,2000$ & 20 & 13 \\
M2 & $180-349,2000$ & 87 & 98 \\
M3 & $1-61,2000$ & 5 & 5 \\
M3 & $180-259,2000$ & 7 & 4 \\
\hline
\end{tabular}

Table 3.4: Observed and simulated snow depths (cm w.e.) at different times and locations.

\begin{tabular}{llll}
\hline Station & Days, year & Observed & Simulated \\
\hline M1 & 39,1999 & 9 & 11 \\
M1 & 107,1999 & 23 & 29 \\
M1 & 346,1999 & 6 & 7 \\
M1 & 65,2000 & 11 & 16 \\
M2 & 65,2000 & 23 & 42 \\
M1 & 344,2000 & 17 & 51 \\
\hline
\end{tabular}

Figure 3.4 shows a comparison of observed and simulated ice melt at M1 for 1999 and 2000 by plotting simulated melt, divided by the ice density $\left(900 \mathrm{~kg} \mathrm{~m}^{-3}\right)$, against relative surface height measured by the sonic ranger. The curves are compared for the period with bare ice, as derived from the sonic ranger, and the snow pit data. For 1999, this implies the period from day 138 until day 309, and for 2000, from day 127 until day 305. For 1999, simulated ice melt equals observed ice melt ( $5.9 \mathrm{~m} \mathrm{w} . \mathrm{e}$ ) because $C_{b}$ was found by matching the ice melt of 1999 . For the period in 2000, simulated ice melt is $6.1 \mathrm{~m}$ w.e. and observed ice melt $6.5 \mathrm{~m}$ w.e. For the winter period, modelled and observed relative surface heights were not compared because the snow density for matching the two curves is not known.

Figure 3.5 compares simulated mass-balance curves for M1, M2 and M3 with stake measurements. The stake readings, which started on day 214 of 1999, were used to anchor the simulated mass-balance curves from that point onwards. The findings suggest that the simulated melt is too low, by 5 to $8 \%$. This might be explained by the slope and aspect of the surface. The stakes were placed on a relatively flat surface, whereas the surrounding area, similar to the grid cell size, mainly faces north, receiving less 
shortwave radiation. Simulated mass balances for M1, M2 and M3 showed to decrease $6 \%, 3 \%$ and $1 \%$, respectively if the slope of the surface was assumed to be zero.

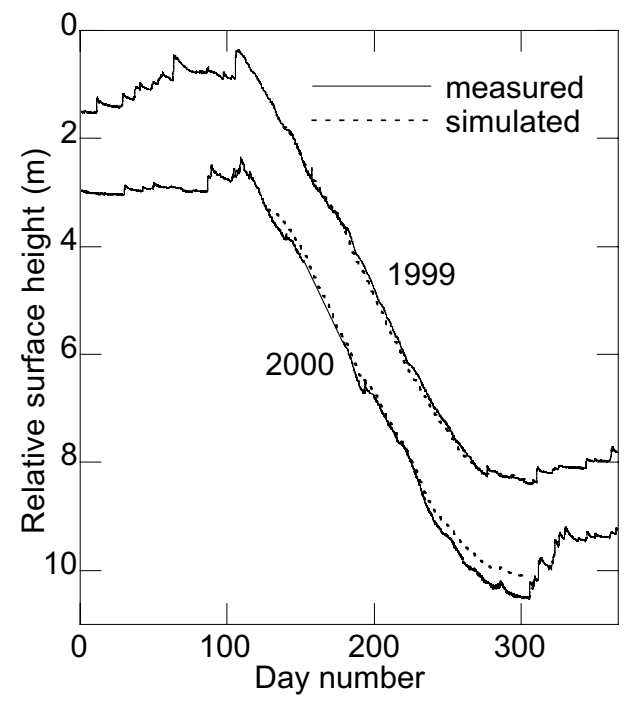

Figure 3.4: Measured and simulated ice-melt curves at M1 for 1999 and 2000. The dashed line represents the simulated ice melt for the grid cell in which M1 is located for the period in which snow does not cover the surface. The records of the sonic ranger (solid lines) show sudden increases in relative surface height, indicating the snowfall events. After these events, the snow settles and the relative surface height decreases again.

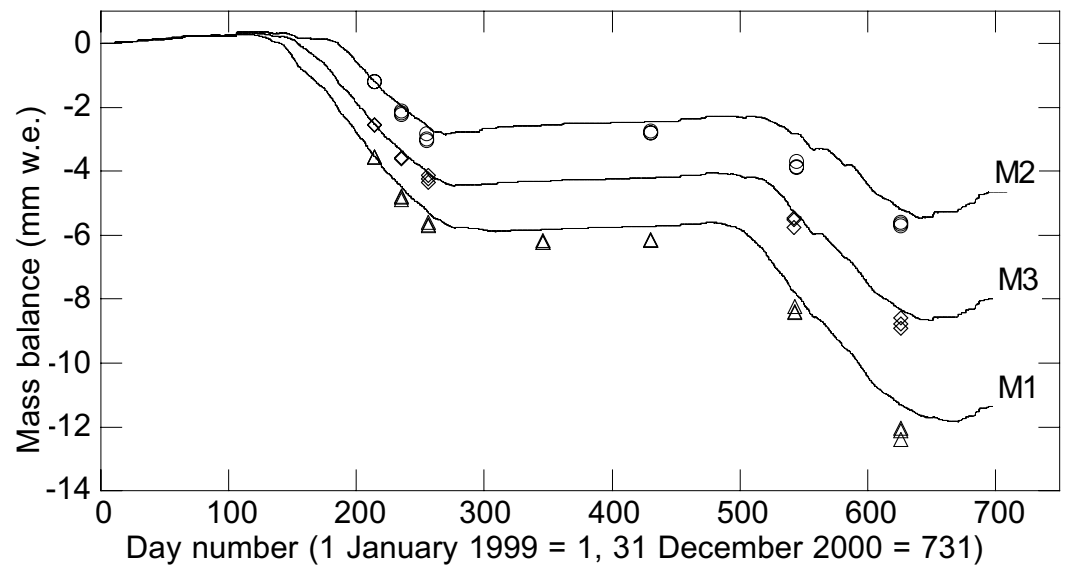

Figure 3.5: Modelled specific mass balance at M1, M2 and M3. The markers indicate the mass-balance measurements from stake readings. At each location, three stakes were measured. 


\subsubsection{SPATIAL DISTRIBUTION OF THE ENERGY FLUXES AND THE SPECIFIC MASS}

\section{BALANCE}

One of the aims of this study is to analyse the spatial distribution of the energy and mass fluxes on the glacier. Figure 3.6 shows the spatial distribution of the mean net shortwave and longwave radiation, the mean turbulent heat fluxes, the mean albedo over 1999 and the mass balance. To explain the distribution of the fluxes, the glacier topography is plotted in Figure 3.6a. The mean specific mass balance is $-0.47 \mathrm{~m}$ w.e. for 1999 and 0.23 $\mathrm{m}$ w.e. for 2000 . The net shortwave heat flux ranges from 10 to $60 \mathrm{~W} \mathrm{~m}^{-2}$ (Figure 3.6c). There is a sharp transition between net shortwave heat fluxes larger than $30 \mathrm{~W} \mathrm{~m}^{-2}$ and values smaller than $20 \mathrm{~W} \mathrm{~m}^{-2}$. This transition indicates the area above which the slopes are steepest, resulting in lower solar radiation reception. Also, the mean albedo of this area is high (Figure $3.6 f$ ) because snow is present throughout the entire year.

The mean longwave heat flux (Figure 3.6d) and the mean turbulent heat flux (Figure 3.6e) vary strongest with altitude and not along the contour lines. This is to be expected because in the model, longwave radiation andthe turbulent heat fluxes depend mainly on air temperature and relative humidity, which are functions of elevation.

Figure 3.7 depicts the mean specific mass balance and snow accumulation of 1999 for 100-m height intervals. The equilibrium line altitude is at $3010 \mathrm{~m}$ a.s.l. The mass-balance gradient is steepest, $-0.006 \mathrm{~m}$ w.e. per $\mathrm{m}$ altitude, in the area where the specific mass balance is negative. This value is somewhat lower than the characteristic value of -0.007 for ablation areas in the Alps (Oerlemans, 2001). At higher altitudes, the massbalance gradient flattens out and equals annual snowfall. Snowfall does not increase linearly with height because at lower altitudes the air temperatures are more frequently too high for snowfall. The calculated annual snow accumulation averaged over the glacier is $1.26 \mathrm{~m}$ w.e for 1999. For 2000, it amounts to $1.82 \mathrm{~m}$ w.e. This means that, $1.74 \mathrm{~m}$ w.e. ablated in 1999 and $1.59 \mathrm{~m}$ w.e. in 2000.

Figure 3.8 displays the energy balance components averaged over 100$\mathrm{m}$ height intervals. Net longwave radiation becomes more negative at higher altitudes and the turbulent heat fluxes decrease with increasing altitude. The mean sensible heat flux exceeds mean latent heat flux at all altitudes. Net shortwave radiation decreases until an altitude of $3350 \mathrm{~m}$ a.s.l. However, it rises again at altitudes above $3350 \mathrm{~m}$ a.s.l. Figure 3.8 also shows that below $3100 \mathrm{~m}$ a.s.l., the annual surface heat flux is positive, which is the sum of the fluxes. Above this altitude, the surface heat flux is approximately zero, implying that there is no melting and the snow or ice pack does not gain or loose heat on an annual basis. 


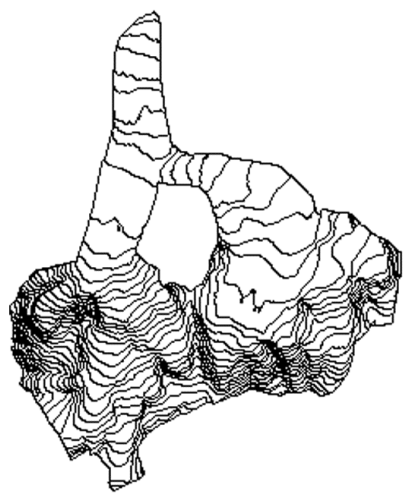

a: Topography, contour lines every $50 \mathrm{~m}$

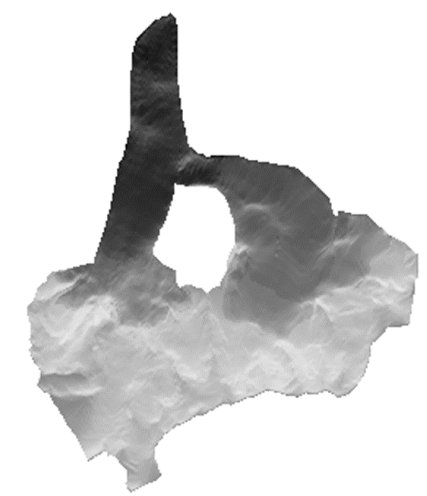

c: Net shortwave radiation $\left(\mathrm{W} \mathrm{m}^{-2}\right)$
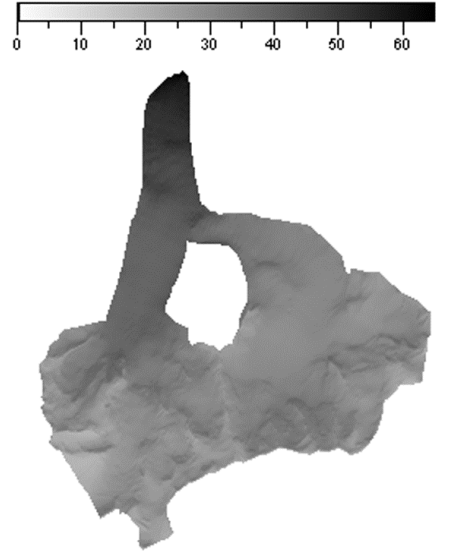

e: Sensible \& latent heat flux $\left(\mathrm{W} \mathrm{m}^{-2}\right)$

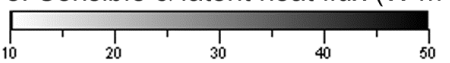

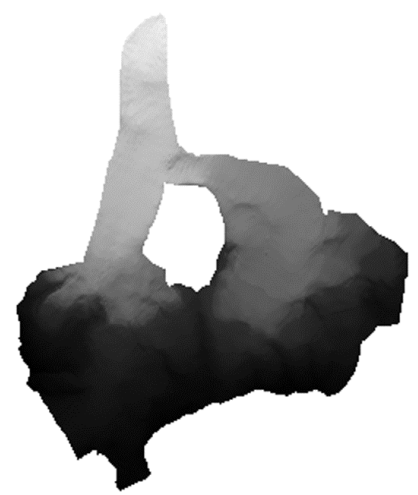

b: Mass balance ( $\mathrm{mm}$ w.e.)
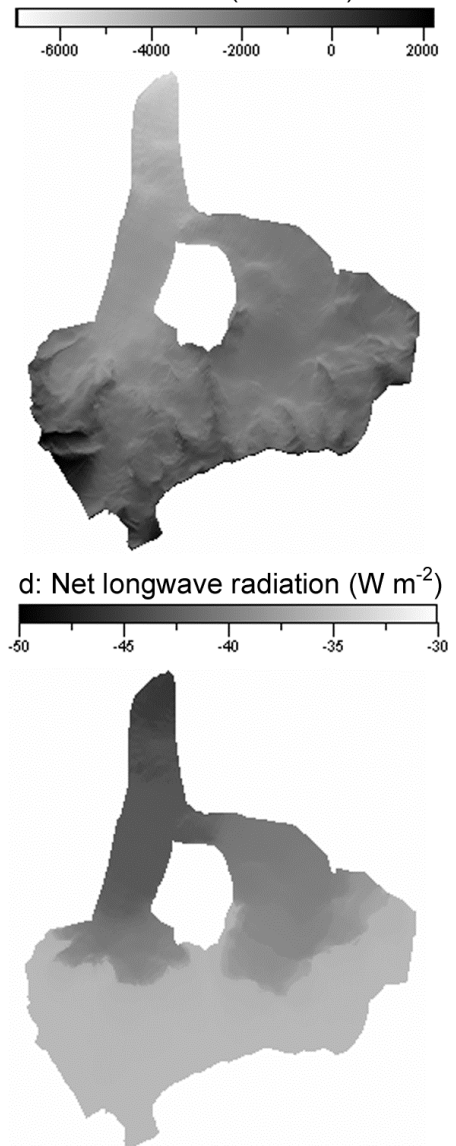

f: Albedo

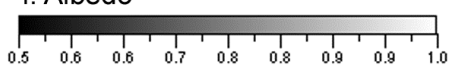

Figure 3.6: Topography of the glacier (a), modelled mass balance of 1999 (b), and net shortwave radiation $(c)$, net longwave radiation $(d)$, latent plus sensible heat flux (e) and albedo (f) averaged over 1999. 


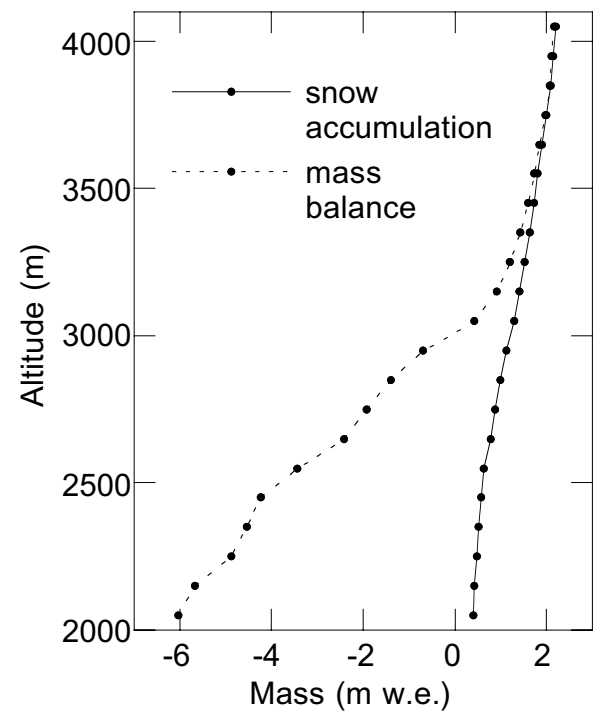

Figure 3.7: Mean modelled specific mass balance and annual snow accumulation averaged over $100 \mathrm{~m}$ height intervals for 1999.

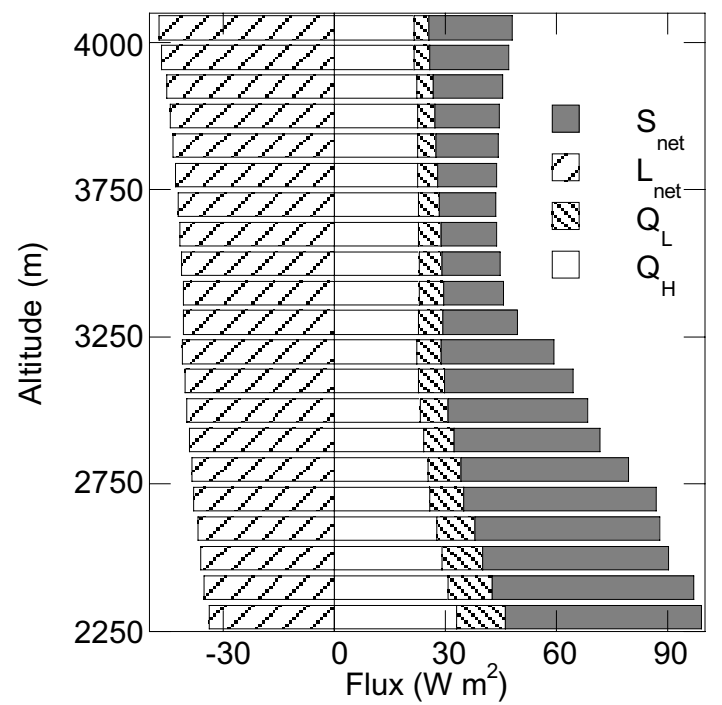

Figure 3.8: Mean modelled annual energy fluxes (net shortwave and net longwave, sensible and latent heat flux) of $100 \mathrm{~m}$ height intervals of 1999.

\subsubsection{TOPOGRAPHICAL EFFECTS ON SOLAR RADIATION}

Regarding the shortwave radiation, it is interesting to examine what exactly causes the variation over the glacier. Figure $3.9 a$ shows the mean incoming shortwave radiation averaged over different height intervals. The 
shortwave radiation does not increase with elevation, which would be expected as the optical air mass decreases with altitude. The effects of shading, slope, aspect, sky obstruction, and terrain reflection explain this pattern. Neglecting these effects, shortwave radiation would increase with altitude (Figure 3.9a) and the mean shortwave radiation impinging on the glacier would increase with $37 \%$, resulting in a decrease in the mass balance of $0.34 \mathrm{~m}$ w.e.
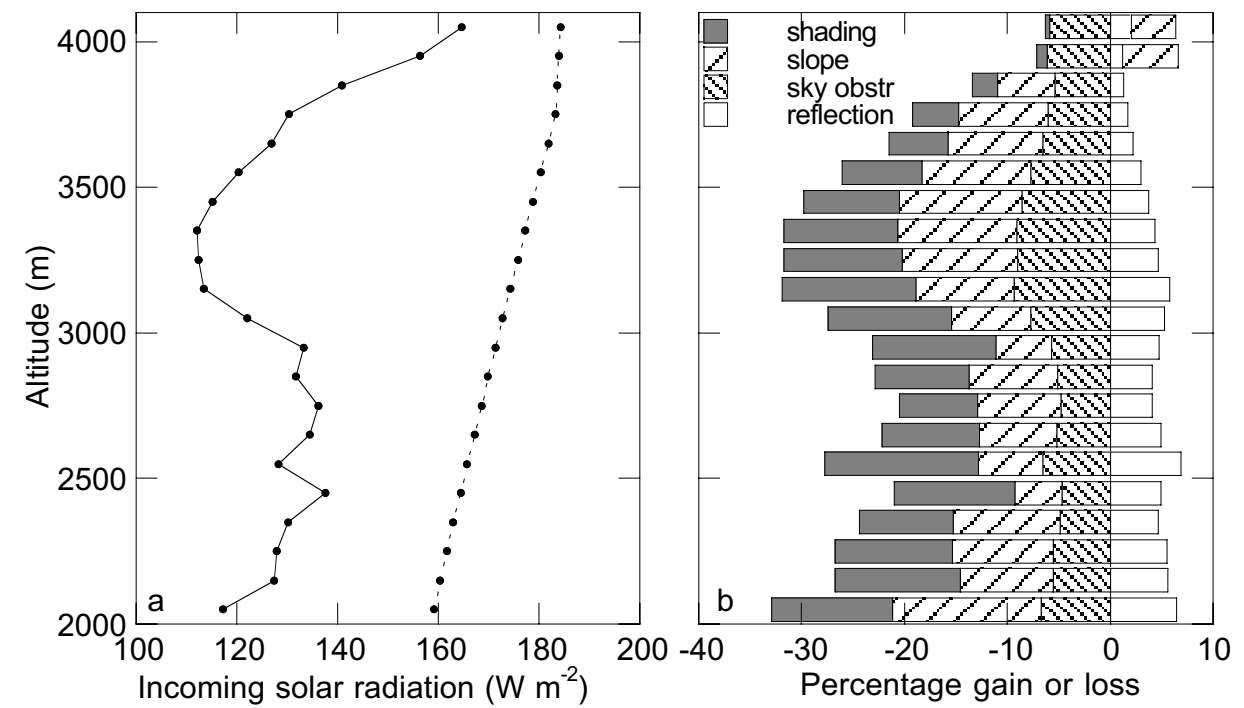

Figure 3.9: (a) The solid line shows the mean modelled incoming solar radiation over $100 \mathrm{~m}$ height intervals of 1999 and the dotted line shows the modelled incoming solar radiation if slope, aspect, shading, sky obstruction and terrain reflection are ignored. (b) Percentage of gain or loss of incoming solar radiation due to these topographical effects.

Figure $3.9 b$ shows the contribution of each of these effects to the annual shortwave radiation impinging on the surface for 100-m height intervals. The amount of reflected radiation from the surrounding terrain is the smallest effect. It contributes on average $4.3 \%$ to the annual mean shortwave incoming radiation on the glacier. Shading reduces the shortwave radiation significantly $(10.0 \%)$. However, it does not reduce shortwave radiation substantially at higher altitudes. Slope and aspect of the surface, determining the angle of incidence, reduce shortwave radiation by $8.5 \%$ because the glacier mainly slopes to the north. On the other hand, at the highest altitudes, slope and aspect enhance shortwave radiation. The reduction of diffuse radiation by sky obstruction plays a significant role too, even at the highest altitudes. It reduces shortwave radiation by $6.7 \%$. Note that these percentages will be less if they are calculated for the ablation period only, since the solar zenith angle is smaller in summer. 
Arnold et al. (1996) also evaluated the effects of topography on the mean shortwave radiation on the Haut Glacier d'Arolla. They found that shading reduces the incoming shortwave radiation by $5.2 \%$, and slope and aspect decrease shortwave reception by $14.7 \%$.

\subsubsection{ENERGY FLUXES AT M1, A SUNNY AND A SHADED LOCATION}

Figure 3.10 shows the daily mean energy fluxes for 1999 and 2000 for the grid cell in which M1 is located. It is clear that incoming shortwave radiation shows an annual variation (Figure 3.10a). In May, the reflected shortwave radiation decreased rapidly because all snow disappeared. Outgoing longwave radiation exceeded incoming longwave radiation for most of the time (Figure 3.10b). The sensible heat flux was always positive
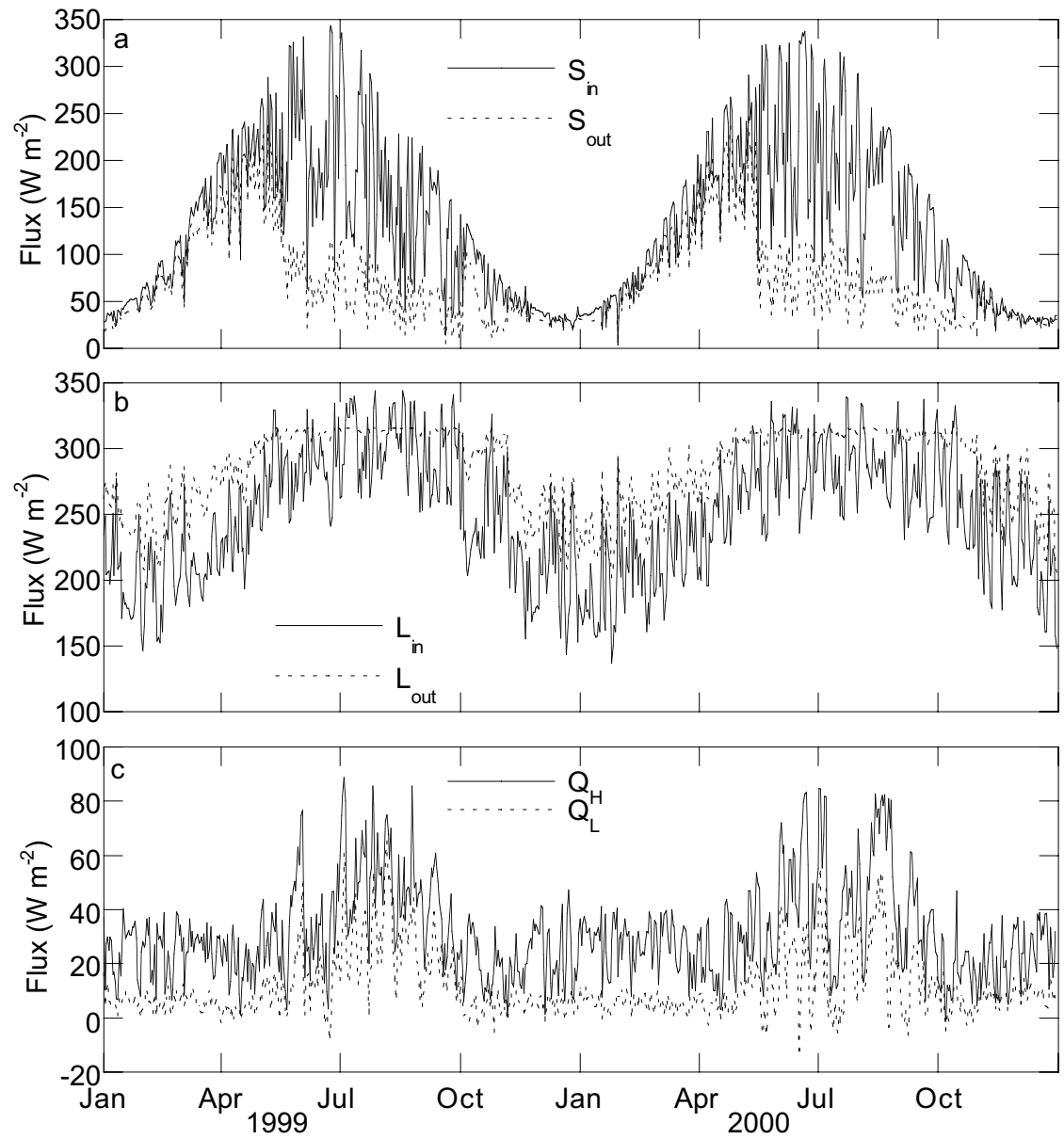

Figure 3.10: Modelled daily mean fluxes of incoming and reflected solar radiation (a), incoming and outgoing ongwave radiation (b) and latent and sensible heat fluxes (c) at M1 for 1999 and 2000. 

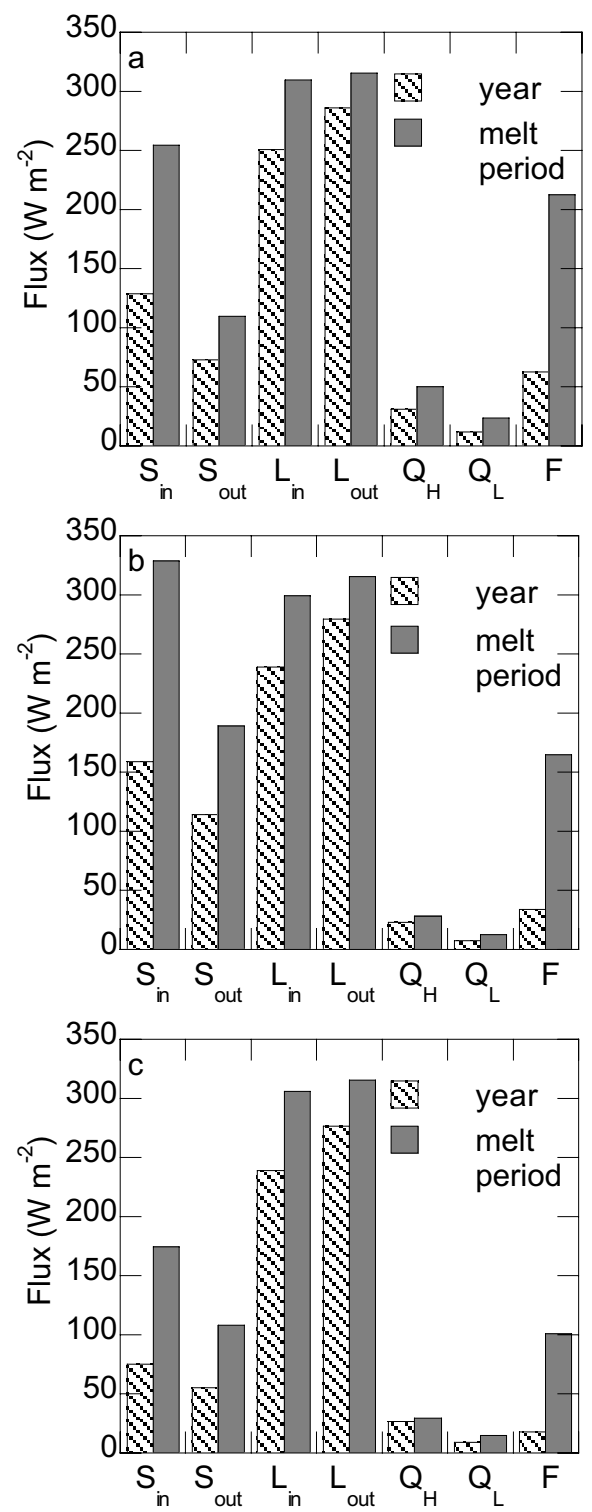

Figure 3.11: Simulated energy fluxes averaged over the year 1999, and over the period when the surface was melting for three locations on the glacier (see text): M1 (a), Msun (b) and Mshad (c). All fluxes are positive towards the surface except for $S_{\text {out }}$ and $L_{\text {out }}$.

and exceeded the latent heat flux (Figure 3.10c). The latent heat flux was sometimes negative, but generally condensation took place. The turbulent heat fluxes were larger in summer. This is to be expected since on summer days the katabatic turbulent exchange coefficient is larger. 
For M1, Figure 3.11 shows the energy fluxes averaged over 1999 and over the time when there was melting. Similarly, mean fluxes were calculated for two other locations on the glacier: Msun and Mshad. Both are located at $2697 \mathrm{~m}$ a.s.l. However, Msun slopes to the west (about $7^{\circ}$ ) and Mshad steeply to the north (about $38^{\circ}$ ). Therefore, Mshad is shaded between sunrise and sunset during $74 \%$ of the year. For Msun, this is $23 \%$, and for M1 44\%. The mean surface energy flux of the melting period equals the energy involved in melting. At M1, melting occurs during $31 \%$ of the year, and at Msun and Mshad, the surface melts during 22\% and 19\% of the year, respectively.

At all locations, the energy fluxes increase when the glacier melts. The longwave heat fluxes are generally the greatest fluxes, although incoming shortwave radiation is the largest flux at Msun during the melt period. The large difference between melt at Msun and Mshad is explained by the difference in shortwave radiation due to the topography at the two locations. Therefore, the specific mass balance at Msun (-2.50 m w.e.) is 2.7 times larger compared to Mshad (-0.93 m w.e.). At M1, the specific mass balance is $-5.78 \mathrm{~m}$ w.e. The turbulent heat fluxes are small at all locations, but still they supply $34 \%$ of the energy involved in the melting at M1, 23\% at Msun, and $40 \%$ at Mshad.

\subsubsection{Climate SENSITIVITY}

Simple climate-sensitivity tests have been carried out for Morteratschgletscher. We altered the air temperature by $1{ }^{\circ} \mathrm{C}$ and precipitation by $10 \%$ and recalculated the mean specific mass balance for 1999. Table 3.5 shows the results.

The temperature sensitivities are larger than those for Hintereisferner (Austria) and Rhonegletscher (Switzerland) as computed by Oerlemans (2000b; 2001). He found a change in the mean specific mass balance of -0.41 $\mathrm{m}$ w.e. for a $1{ }^{\circ} \mathrm{C}$ temperature perturbation for both Rhonegletscher and Hintereisferner. For Pasterze (Austria), Greuell and Böhm (1998) computed a much larger change in the specific mass balance for a $1{ }^{\circ} \mathrm{C}$ warming: $-0.90 \mathrm{~m}$ w.e. The change in the specific mass balance to a perturbation in precipitation is similar to the precipitation sensitivity of Hintereisferner (0.28 m w.e.) and Rhonegletscher (0.26 m w.e.) as found by Oerlemans (2000b; 2001).

An increase in precipitation affects the mean specific mass balance of the glacier directly and indirectly. Without a perturbation, the mean snowfall on the glacier of 1999 is $1.26 \mathrm{~m}$ w.e. Therefore, a change of $10 \%$ in precipitation cannot solely explain the change in the mean specific mass balance of about $0.18 \mathrm{~m}$ w.e. The remaining part should be explained by the albedo feedback. Changing the air temperature mainly affects the incoming and outgoing longwave radiation and the turbulent heat fluxes, enhanced 
by the albedo feedback mechanism. According to Greuell and Böhm (1998), the albedo feedback causes roughly a doubling of the climate sensitivity.

Table 3.5: Change in the mean specific mass balance $(\Delta B)$ of 1999 with respect to changes in air temperature $\left(T_{a}\right)$ and precipitation $(P)$.

\begin{tabular}{ll}
\hline Forcing & $\Delta B$ ( $m$ w.e. $)$ \\
\hline$T_{a}+1^{\circ} \mathrm{C}$ & -0.70 \\
$T_{a}-1{ }^{\circ} \mathrm{C}$ & 0.65 \\
$P+10 \%$ & 0.17 \\
$P-10 \%$ & -0.16 \\
\hline
\end{tabular}

\subsection{CONCLUDING REMARKS}

This research attempted to study the spatial distribution of the energy and mass-balance fluxes of Morteratschgletscher, by using a twodimensional mass-balance model. The ablation rate was calculated from the surface energy flux of the glacier. Meteorological data from four synoptic weather stations served as input for the model. Since Morteratschgletscher is located between high mountains, we corrected shortwave radiation for shading, aspect, slope, reflection from the slopes, and obstruction of the sky. We derived the albedo from snow depth and snow age, by following Oerlemans and Knap (1998). We used a method of Oerlemans and Grisogono (2002) to calculate the turbulent heat fluxes within the glacier boundary layer. The model was run for two model years.

The comparisons of model results with observations from automatic weather stations located on Morteratschgletscher lead us to believe that the model performs well. The residual standard deviation between calculated and observed daily radiation fluxes is $<22 \mathrm{~W} \mathrm{~m}^{-2}$. Modelled and measured snow accumulation reveal discrepancies. However, optimising the snow accumulation parameterisation scheme is difficult because the spatial distribution of snow accumulation is hard to measure. The observed specific mass balances measured with stakes and a sonic ranger at three locations appear to exceed the mass balances modelled for the grid cells in which the stations are located. The slope of the surface explains this to a large extent because the stations are placed on relatively horizontal surfaces, whereas the grid cells are inclined towards the north.

In the future, the albedo scheme of the model should be improved because the parameterisation that was used, was derived from a 1-year record measured at M1 by Oerlemans and Knap (1998). It is likely that the albedo parameters differ across the glacier due to variations in debris concentration. 
Then, modelled turbulent heat fluxes should be compared to measurements. It would be very useful to observe the turbulent heat fluxes by eddy correlation measurements over a longer period of time in order to test the model of Oerlemans and Grisogono (2002) and to determine a value for $C_{b}$ explicitly.

The parameter sensitivity test shows that the uncertainty in the fractional cloud cover significantly influences the modelled mass balance. Consequently, an improved method of estimating the fractional cloud cover is desirable.

The model is useful for investigating the spatial pattern of the energy and mass-balance fluxes. The fluxes vary mainly with elevation, but shortwave radiation, especially, also varies along the contour lines and supplies most of the melting energy. The results illustrate that the mean shortwave radiation on the glacier would be $37 \%$ larger if the effects of the topography were discounted. This would lead to a decrease of $0.34 \mathrm{~m}$ w.e in the mean specific mass balance of Morteratschgletscher. We conclude that it is important for mass balance modelling to take into account the topographic effects on shortwave radiation. The mean specific mass balance changes about $0.67 \mathrm{~m}$ w.e. if the free-atmospheric air temperature differs by $1{ }^{\circ} \mathrm{C}$, and $0.17 \mathrm{~mm}$ w.e. if precipitation changes by $10 \%$.

In the future, this mass-balance model will be used for several purposes. Firstly, the sensitivity of the specific mass balance to climate changes will be studied in more detail. Secondly, a mass-balance reconstruction of Morteratschgletscher will be generated from historical meteorological records.

Acknowledgements - We would like to thank the people of the Ice \& Climate Group of the IMAU, reviewers G. Wendler and R. Hock, and Scientific Editor, R. Naruse, for numerous helpful comments made on the original draft of this paper. We are grateful to Angie Souren for improving the English, and Meteo Schweiz for providing the meteorological data.

\section{REFERENCES}

Arnold, N.S.I., Willis, I.C., Sharp, M.J., Richards, K.S. and Lawson, W.J. 1996. A distributed surface energy-balance model for a small valley glacier, I, Development and testing for Haut Glacier d'Arolla, Valais, Switzerland. Journal of Glaciology, 42(140), 77-89.

Braithwaite, R.J. 1995. Positive degree-day factors for ablation on the Greenland ice sheet studied by energy-balance modelling. Journal of Glaciology, 41(137), 153-160.

Dozier, J. and Frew, J. 1990. Rapid calculation of terrain parameters for radiation modeling from digital elevation data. IEEE Transactions on Geosciences and Remote Sensing, 28(5), 963-969. 
Escher-Vetter, H. 2000. Modelling meltwater production with a distributed energy balance method and runoff using a linear reservoir approach - results from Vernagtferner, Oetztal Alps, for the ablation seasons 1992 to 1995. Zeitschrift für Gletscherkunde und Glazialgeologie, 36, 119-150.

Greuell, W. 1992. Hintereisferner, Austria: mass-balance reconstruction and numerical modelling of the historical length variations. Journal of Glaciology, 38(129), 233-244.

Greuell, W., Knap, W.H. and Smeets, P.C. 1997. Elevational changes in meteorological variables along a midlatitude glacier during summer. Journal of Geophysical Research, 102(D22), 25,941-25,954.

Greuell, W. and Böhm, R. 1998. 2 m temperatures along melting mid-latitude glaciers, and implications for the sensitivity of the mass balance to variations in temperature. Journal of Glaciology, 44(146), 9-20.

Gueymard, C. 1993. Critical analysis and performance assessment of clear-sky solar irradiance models using theoretical and measured data. Solar Energy 51(2), 121-138, 1993.

Hock, R. and Noetzli, C. 1997. Areal melt and discharge modelling of Storglaciären, Sweden. Annals of Glaciology, 24, 211-216.

Hock, R. 1999. A distributed temperature index ice and snow melt model including potential direct solar radiation. Journal of Glaciology, 45(149), 101-111.

Houghton, H.G. 1954. On the annual heat balance of the Northern Hemisphere. Journal of Meteorolgy, 11(1), 1-9.

Iqbal, M. 1983. An Introduction to Solar Radiation. New York, Academic Press.

Konzelmann, T., Van de Wal, R.S.W., Greuell, W., Bintanja, R., Henneken, E.A.C. and Abe-Ouchi, A. 1994. Parameterization of global and longwave incoming radiation for the Greenland Ice Sheet. Global and Planetary Change, 9, 143-164.

Meyers, T.P. and Dale, R.F. 1983. Predicting daily insolation with hourly cloud height and coverage. Journal of Climate and Applied Meteorology, 22(4), 537-545.

Oerlemans, J. 1992. Climate sensitivity of glaciers in southern Norway: application of an energy-balance model to Nigardsbreen, Hellstugubreen and Alfotbreen. Journal of Glaciology, 38(129), 223-232.

Oerlemans, J. and Knap, W.H. 1998. A 1 year record of global radiation and albedo in the ablation zone of Morteratschgletscher, Switzerland. Journal of Glaciology, 44(147), 231-238.

Oerlemans, J. 2000a. Analysis of a 3 year meteorological record from the ablation zone of Morteratschgletscher, Switzerland: energy and mass balance. Journal of Glaciology, 46(155), 571-579.

Oerlemans, J. 2000b. Holocene glacier fluctuations: is the current rate of retreat exceptional? Annals of Glaciology, 31, 39-44.

Oerlemans, J. 2001. Glaciers and Climate Change. Rotterdam, A.A. Balkema Publishers.

Oerlemans, J. and Grisogono, B. 2002. Glacier wind and parameterisation of the related surface heat flux. Tellus, 54A(5), 440-452.

Oerlemans, J. and Klok, E.J., 2002. Energy balance of a glacier surface: analysis of AWS data from the Morteratschgletscher, Switzerland. Arctic, Antarctic and Alpine Research, 34(123), 115-123.

Schneeberger, C., Albrecht, O., Blatter, H., Wild, M. and Hock, R. 2001. Modelling the response of glaciers to a doubling in atmospheric $\mathrm{CO}_{2}$ : a case study of Storglaciären, northern Sweden. Climate Dynamics, 17(11), 825-834. 
Schwarb, M. 2000. The Alpine precipitation climate. Evaluation of a high-resolution analysis scheme using comprehensive rain-gauge data. Diss. ETH No. 13911, Institute for Climate Research, ETH Zürich.

Smith, W.L. 1966. Note on the relationship between total precipitable water and surface dewpoint. Journal of Applied Meteorology, 5(5), 726-727.

Wallinga, J. and Van de Wal, R.S.W. 1998. Sensitivity of Rhonegletscher, Switzerland, to climate change: experiments with a one-dimensional flowline model. Journal of Glaciology, 44(147), 383-393. 
Note to Chapter 4: Modelled climate sensitivity of the mass balance of Morteratschgletscher and its dependence on albedo parameterisation :

"This is a preprint of an article accepted for publication in International Journal of Climatology Copyright (C (2003) (Royal Meteorlogical Society)" 


\title{
MODELLED CLIMATE SENSITIVITY OF THE
MASS BALANCE OF MORTERATSCHGLETSCHER AND ITS DEPENDENCE ON ALBEDO \\ PARAMETERISATION*
}

\begin{abstract}
This chapter presents a study of the climate sensitivity of the mass balance of Morteratschgletscher in Switzerland. We ran a two-dimensional mass balance model for the period 1980 to 2002 and compared our mass-balance simulations with measurements carried out on Morteratschgletscher and six other glaciers. We calculated the mass-balance sensitivity by perturbing the air temperature by values ranging from -2 to $+2 \mathrm{~K}$ and precipitation by values ranging from -20 to +20 percent. The mass-balance sensitivity to temperature and precipitation are $-59 \mathrm{~cm}$ w.e. $\mathrm{a}^{-1} \mathrm{~K}^{-1}$ and at $17 \mathrm{~cm}$ w.e. $\mathrm{a}^{-1}$ per 10 percent respectively. The albedo parameterisation that we used for these simulations relates the snow albedo to snow age and snow depth, whereas it considers the ice albedo constant in time and space. As the chosen albedo scheme is often the largest error source in mass-balance models, we investigated the impact of using three other albedo parameterisations on mass-balance sensitivity. One parameterisation uses ice albedo values that vary in space and were acquired from a Landsat image. Another parameterisation calculates the snow albedo from accumulated daily maximum temperatures since snowfall. The third parameterisation is the simplest and uses two constant albedo values, one for snow and one for ice. The differences between the mass-balance sensitivities calculated from the different albedo parameterisations are generally small. However, when the simplest parameterisation is used, the mass-balance sensitivity to temperature decreases to -52 $\mathrm{cm}$ w.e. $\mathrm{a}^{-1} \mathrm{~K}^{-1}$. This is mainly due to the constant snow albedo, which implies that the albedo feedback is not fully considered. For an accurate estimate of the mass-balance sensitivity, the albedo parameterisation should capture the process of a decreasing snow albedo when a snow pack gets older or thinner.
\end{abstract}

\footnotetext{
" Based on: Klok, E.J. and Oerlemans, J. 2003. Modelled climate sensitivity of the mass balance of Morteratschgletscher and its dependence on albedo parameterisation. International Journal of Climatology, submitted.
} 


\subsection{INTRODUCTION}

As volume and mass balance of glaciers vary with changing climate, many model studies and measurements have been carried out to investigate this link (e.g. Oerlemans and Hoogendoorn, 1989; Oerlemans, 1992; Jóhannesson et al., 1995, Greuell and Böhm, 1998; Vallon et al., 1998; Kayastha et al. 1999; Klok and Oerlemans, 2002 (Chapter 3); De Ruyter de Wildt and Oerlemans, 2003).

Generally, net shortwave radiation is the most important energy source for the melting process of glaciers. Therefore, glacier melt rates depend to a large degree on the surface albedo. Van de Wal et al. (1992) concluded from measurements on Hintereisferner (Austria) that $70 \%$ of the variation in ablation is explained by differences in the surface albedo. Nevertheless, within mass-balance models, the albedo scheme is often regarded as the largest source of error (Arnold et al., 1996; Klok and Oerlemans, 2002 (Chapter 3)). Usually, albedo parameterisations cannot account for all spatial and temporal variations in the surface albedo. Several studies demonstrated that the modelled mass balance is very sensitive to small changes in the albedo. Oerlemans and Hoogendoorn (1989) showed that for a perturbation in the surface albedo of 0.1 , the change in the mass balance of a fictitious glacier in the Alps varies between 0.5 to $1.5 \mathrm{~m}$ w.e. $\mathrm{a}^{-1}$, depending on elevation. The largest sensitivity was found at the glacier terminus. Munro (1991) found a change in the mass balance of $0.66 \mathrm{~m}$ w.e. $\mathrm{a}^{-1}$ for Peyto glacier, Canada, when the albedo was increased by $5 \%$ and a change of $-0.83 \mathrm{~m}$ w.e. $\mathrm{a}^{-1}$ when the albedo was decreased by $5 \%$. In the latter two studies, the albedo perturbation was applied to both snow and ice surfaces. Klok and Oerlemans (2002) (Chapter 3) investigated the effect of a change in only the ice albedo for Morteratschgletscher and found a lower sensitivity. The mass balance decreased with $0.15 \mathrm{~m}$ w.e. $\mathrm{a}^{-1}$ when the ice albedo was lowered with 0.08 .

Also the mass-balance sensitivity to a change in climate depends to a large extent on the parameterisation of albedo and albedo feedback. The albedo feedback enhances the response of the mass balance to a change in climate in the sense that changes in temperature and snowfall influence the melt rate and the average albedo of the glacier, which in turn influences the melt rate. Several processes are responsible for a change in average glacier albedo when, for instance, the temperature increases. First of all, a temperature increase causes more melting. Therefore, snow disappears earlier in the melt season, the duration of the period of exposed glacier ice increases, and the average albedo becomes lower. Secondly, a temperature increase influences the growth of ice crystals, resulting in larger grain sizes, which have a lower albedo. Thirdly, increased melt rates result in a larger melt water content at the surface, which also causes a decrease in albedo. 
Fourthly, increased melt rates result in thinner snow packs and lower albedos because the effect of the lower albedo of the underlying ice or debris is greater when snow depth decreases. Lastly, a temperature increase also leads to a decrease in snowfall. Less fresh snow implies lower albedos and also implies thinner snow packs and a longer duration of the period of exposed ice.

Greuell and Böhm (1998) demonstrated the effect of the albedo feedback on the mass-balance sensitivity of an Austrian glacier (Pasterze). They showed that the sensitivity to a warming of $1 \mathrm{~K}$ increased by $91 \%$ (from -0.47 to $-0.90 \mathrm{~m}$ w.e. $\mathrm{a}^{-1}$ ). De Ruyter de Wildt and Oerlemans (2003) investigated the effect of the albedo parameterisation on the mass-balance sensitivity of Vatnajøkull. They found a mass-balance sensitivity of $-0.65 \mathrm{~m} \mathrm{w}$.e. $\mathrm{a}^{-1}$ for an increase in temperature of $1 \mathrm{~K}$ when they modelled the snow albedo as a function of snow age. However, when they used a constant snow albedo of 0.72 , the mass-balance sensitivity decreased by $25 \%$.

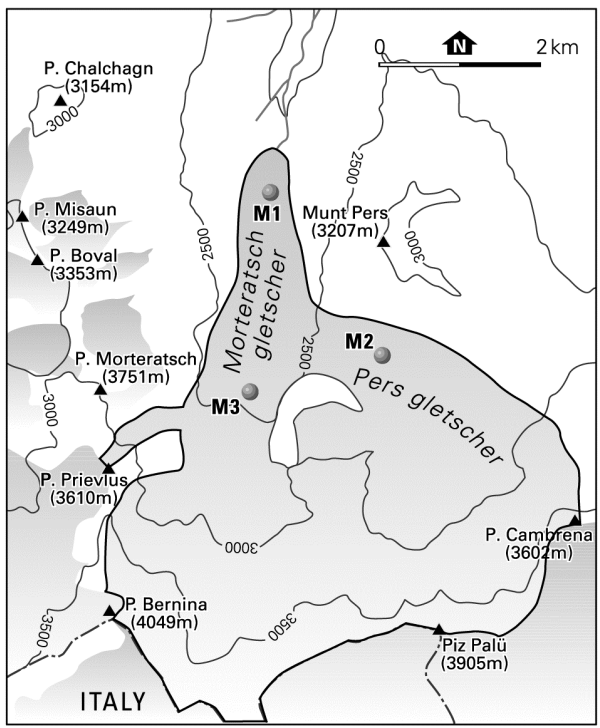

Figure 4.1: Morteratschgletscher $\left(17 \mathrm{~km}^{2}\right)$. Outlines of the glacier are indicated as well as the locations of the weather stations (M1, M2 and M3).

To address the impact of the albedo parameterisation on the modelled mass balance, this study evaluates in more detail the differences between various albedo parameterisations. We focused on the modelled response of the mass balance to climate change. For this purpose, we used the twodimensional mass-balance model of Klok and Oerlemans (2002) (Chapter 3). They developed this model to investigate the spatial distribution of the energy and mass-balance fluxes of a glacier. They applied it to Morteratsch- 
gletscher located in southeast Switzerland $\left(46^{\circ} 24^{\prime} \mathrm{N} 8^{\circ} 02^{\prime} \mathrm{E}\right)$ (Figure 4.1), and simulated the mass balance for two years: 1999 and 2000.

For the present research, we ran the model for a period of 23 years: from 1980 to 2002. We also applied the model to Morteratschgletscher and used meteorological input from synoptic weather stations located near the glacier. We briefly describe the mass-balance model in Section 4.2. The albedo parameterisation that we used for the simulations follows Oerlemans and Knap (1998). We studied the performance of the model and compared the modelled mass balance with accumulation and ablation measurements carried out on the glacier tongue (described in Section 4.3). We also examined differences between the modelled mass balance of Morteratschgletscher and mass-balance measurements carried out on other glaciers in the Alps (Section 4.4). Then, we calculated the annual mass balance of Morteratschgletscher over the period 1980 to 2002 by using three other albedo parameterisations. The different albedo parameterisations are explained in Section 4.5. We estimated the mass-balance sensitivity to changes in air temperature and precipitation for the four albedo parameterisations. We perturbed these variables over the period 1980-2002 and then computed the average change in the mass balance. We present and discuss the results in Sections 4.6 and 4.7.

\subsection{THE TWO-DIMENSIONAL MASS-BALANCE MODEL}

As we used the two-dimensional mass-balance model of Klok and Oerlemans (2002) (Chapter 3), we only give a brief explanation here and refer to the earlier Chapter 3 for a more extensive discussion.

The mass-balance model is based on the surface energy balance of a glacier. Its spatial resolution is $25 \mathrm{~m}$ and half-hourly time steps are used. The model accounts for the effects of shading, slope, aspect, obstruction of the sky and reflection from the surrounding slopes on the incoming shortwave radiation. The albedo of each grid cell is estimated with the method of Oerlemans and Knap (1998), in which the snow albedo depends on the snow depth and the time since the previous snowfall event. We defined a snowfall event as a day with a snowfall $>3 \mathrm{~mm}$ w.e. The parameterisation of the turbulent heat fluxes follows the model of Oerlemans and Grisogono (2002). The turbulent exchange coefficient of this parameterisation was used to tune the model results to glacier melt measured at M1 (Klok and Oerlemans, 2002 (Chapter 3)). The conductive heat flux into the glacier is estimated from a simple 2-layer subsurface model. The temperature of the lowest boundary is fixed at $273.15 \mathrm{~K}$ because measurements indicated that the glacier is temperate (Schwerzmann, personal communication).

The model is driven by meteorological input from synoptic weather stations of Meteo Schweiz located in the vicinity of Morteratschgletscher. 
We used half-hourly means of air temperature, relative humidity and incoming shortwave radiation from the stations Samedan and Corvatsch. Samedan is located at $1705 \mathrm{~m}$ a.s.l. and about $12 \mathrm{~km}$ from the Morteratschgletscher and Corvatsch at $3315 \mathrm{~m}$ a.s.l. and about $8.5 \mathrm{~km}$ from the glacier. Shortwave radiation was used to estimate cloud cover, which is needed for the shortwave and longwave radiation parameterisations. We computed the amount of snowfall from daily precipitation data measured at Pontresina and used a precipitation gradient of $0.5 \mathrm{~mm} \mathrm{a}^{-1} \mathrm{~m}^{-1}$. Pontresina is located at $1774 \mathrm{~m}$ a.s.l., at about $8 \mathrm{~km}$ from the glacier.

We ran the model for 23 years (1980 to 2002). The first two years were used to initiate the model because we did not have a complete input data set for these years. Temperature measurements at Corvatsch began at 17 October 1980, and at Samedan and Corvatsch, relative humidity recordings started at 13 May 1981. For the period up to these dates, average temperatures or relative humidity were used, based on the available data. We did not incorporate the results for the first two years into this study.

\subsection{COMPARISON OF SIMULATIONS WITH MEASUREMENTS}

To study the performance of the model, we compared simulated snow depth, surface melt and mass balance with measurements carried out at the locations M1, M2 and M3 (Figure 4.1). The Institute for Marine and Atmospheric Research Utrecht operates automatic weather stations there and measures among others snow depth, ablation and surface height from stakes, sonic rangers and snow density profiles (Klok and Oerlemans, 2002 (Chapter 3); Oerlemans and Klok, 2002).

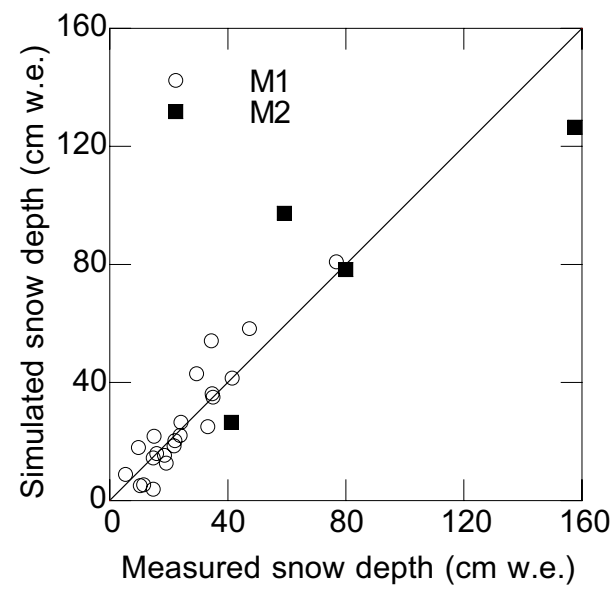

Figure 4.2: Simulated snow depth as function of measured snow depth at M1 and M2. 


\subsubsection{SNOW DEPTH}

We derived snow depth from snow profiles taken at M1 and M2. At M1, snow pits have been dug at an average frequency of three times each winter since 1995. At M2, four snow profiles have been taken since 2000. Figure 4.2 reveals that simulated and measured snow depth are close to the 1:1 line, especially for M1. Figure 4.3 shows simulated and measured snow depth as function of time, for M1. For this location, the mean difference between simulated and measured snow depth is $1 \mathrm{~cm}$ w.e. and the standard deviation $7 \mathrm{~cm}$ w.e. For M2, the mean difference is $-2 \mathrm{~cm}$ w.e. and the standard deviation $26 \mathrm{~cm}$ w.e. On average, measured snow depth at M1 was overestimated with $4 \%$, and it was underestimated with $3 \%$ for M2.

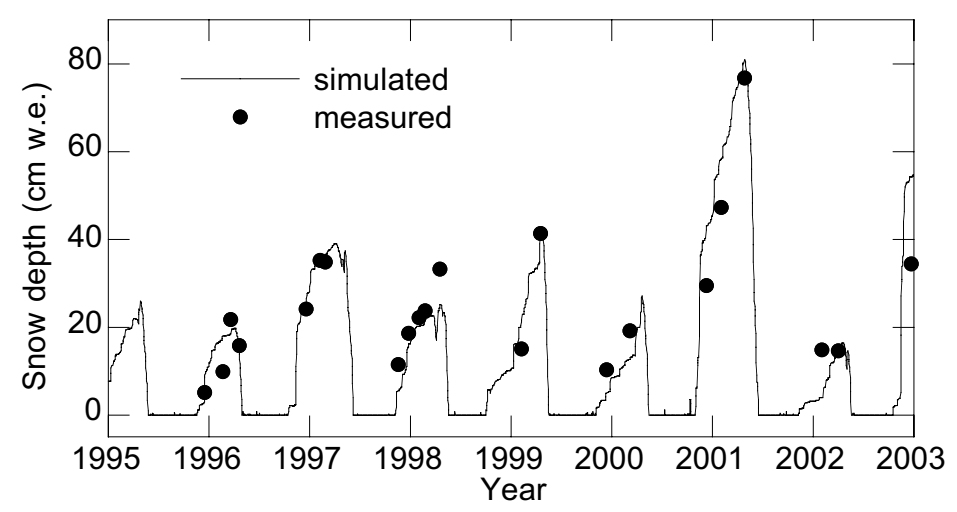

Figure 4.3: Simulated and measured snow depth at M1 as function of time.

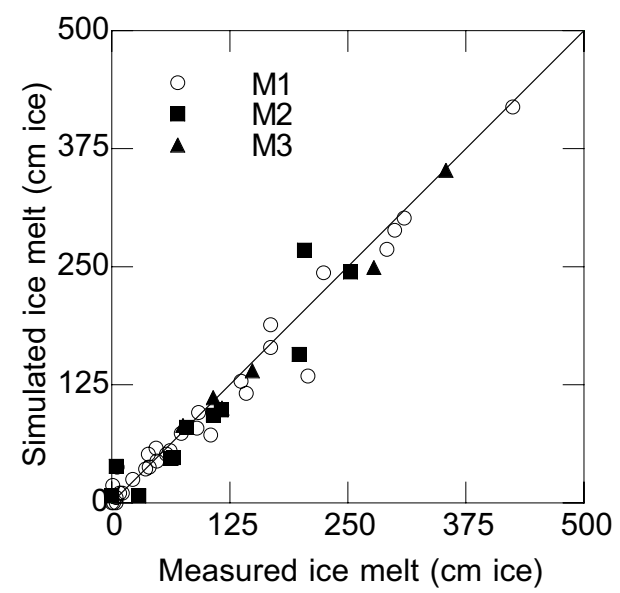

Figure 4.4: Simulated surface melt between two stake readings as function of measured surface melt estimated from three stakes at each location. 


\subsubsection{SURFACE MELT}

Stake readings are carried out at all three locations all the time. At each location, three stakes are drilled into the ice. The distance between the stakes is typically $20 \mathrm{~m}$. Surface melt is estimated as the average of three stake readings. At M1, stake measurements have been made at an average frequency of about four times per year since 1995, at M2 four times per year since 1999, and at M3, three times a year since 1999.

Figure 4.4 shows the amount of simulated ice melt between two stake readings as function of measured melt derived from the stakes. The mean difference between simulations and measurements is $-2,-2$ and $-5 \mathrm{~cm}$ ice for M1, M2 and M3 respectively. This implies that the model slightly underestimates ice melt at all locations. The respective standard deviations are 16, 24 and $11 \mathrm{~cm}$ ice. At M1, total accumulated simulated surface melt was 3\% less than measured from stakes. At M2, it was 3\% less and at M3, $4 \%$ less.

At all locations, also sonic rangers measure surface melt. For M1, a continuous record since 1998 was available. Records for periods in 1999 and 2000 were available for M2 and M3. Table 4.1 presents the results of the comparisons between surface ice melt derived from the sonic rangers and simulated ice melt. At M1, simulated surface melt is overestimated by $2 \%$ compared to the measurements, but at the other two locations simulated ice melt is underestimated by $\sim 10 \%$.

Table 4.1: Measured (from the sonic ranger) and simulated surface melt ( $m$ w.e.).

\begin{tabular}{lllll}
\hline Location & Period & $\begin{array}{l}\text { Measured } \\
\text { mice }\end{array}$ & $\begin{array}{l}\text { Simulated } \\
\text { m ice }\end{array}$ & $\begin{array}{l}\text { Difference } \\
\text { m ice }\end{array}$ \\
\hline M1 & 15 Jul 1998 - 20 Sep 2002 & 29.37 & 30.09 & 0.72 \\
M2 & 29 Jul 1999 - 26 Sep 1999 & 2.19 & 1.94 & -0.25 \\
M2 & 28 Jun 2000 - 20 Sep 2000 & 3.27 & 2.70 & -0.57 \\
M3 & 30 Jul 1999 - 22 Sep 1999 & 2.32 & 2.09 & -0.23 \\
M3 & 28 Jun 2000 - 16 Sep 2000 & 3.48 & 3.40 & -0.08 \\
\hline
\end{tabular}

Figure 4.5 depicts accumulated simulated surface ice melt at M1 and compares them to data from the sonic ranger and the stake readings. The arrow indicates the start of the record of the sonic ranger. The stake readings record starts one year later. The accumulated simulated surface melt is in between the two measured records. At the end of the ablation period of 2002 (indicated by a dotted line), the simulations overestimated accumulated ice melt by $0.79 \mathrm{~m}$ ice compared to data from the sonic ranger and underestimated accumulated ice melt by $1.6 \mathrm{~m}$ ice compared to the stake measurements. This implies that the surface mass balance at M1 is very well simulated, but the discrepancy between stakes and sonic ranger is 
large. The difference is $8 \%$, which can be regarded as a measure of the accuracy of the measured ice melt.

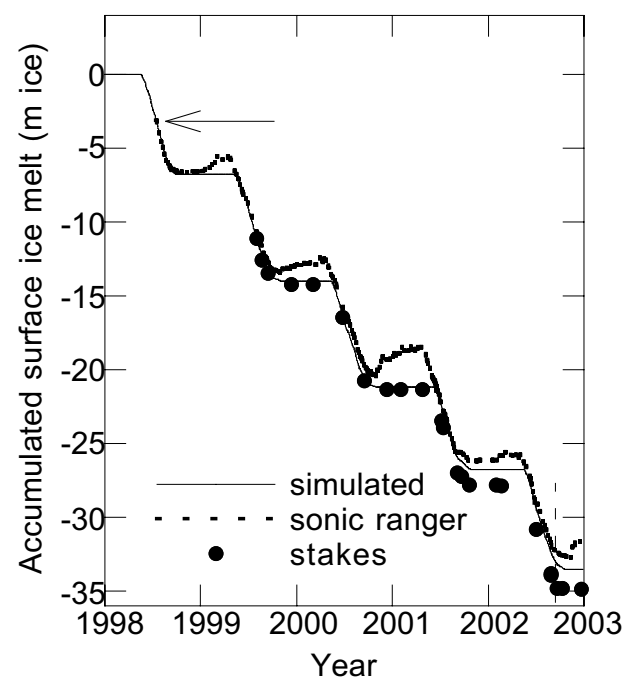

Figure 4.5: Surface ice melt at M1 simulated with the mass-balance model and measured with stakes and sonic ranger. The sonic ranger also shows snow depth ( $m$ snow) in the winter months. The arrow indicates the start of the sonic data record and the dotted line indicates the end of the ablation period of 2002.

\subsection{MASS-BALANCE CALCULATIONS FOR THE PERIOD 1980-2002}

The net mass balance of a glacier is normally measured over a hydrological year, which runs from 1 October to 30 September. We calculated the net mass balance over this period for Morteratschgletscher from 1982 until 2002. Net mass balance, snowfall and melt are depicted in Figure 4.6. All simulated net mass balances are negative, except for 2001. Compared to the other years, this year received most snow: $197 \mathrm{~cm}$ w.e., which is $81 \%$ more than the average over 1982-2002. The average net balance is $-78 \mathrm{~cm}$ w.e. Years with high annual snowfall often coincide with low annual melt rates and vice versa (see years 1997, 1998, 2001). This is presumably due to the albedo feedback because high snowfall amounts signify a shorter duration of the period of bare ice and thus a higher average albedo, which in turn leads to a decrease in the melt rate.

We compared the modelled annual mass balance of Morteratschgletscher to the measured mass balance of six nearby glaciers (Figure 4.7). Overall, the simulated net mass balance of Morteratschgletscher is somewhat lower than the measurements of these six glaciers. This might be caused by regional differences in climate or by the uncertainties in the 
model calculations. For instance, snowfall could have been underestimated for the accumulation area. Due to the absence of measurements in the accumulation area, we could not validate the mass balance model for this area.

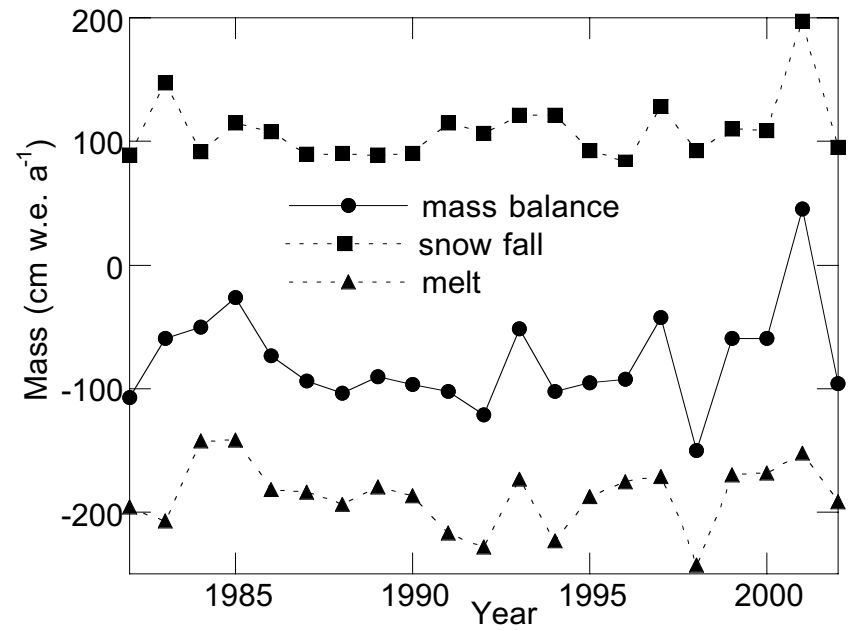

Figure 4.6: Simulated net mass balance by using albedo parameterisation (I), annual snowfall, and melt averaged over Morteratschgletscher.

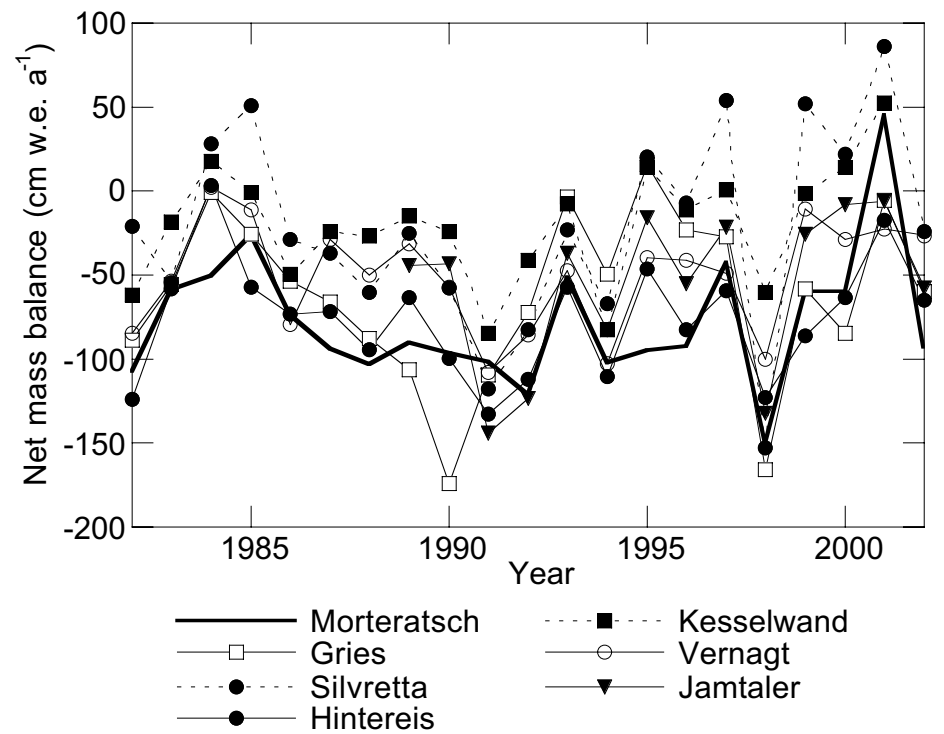

Figure 4.7: Simulated net mass balance of Morteratschgletscher and measured net mass balance of six other glaciers in the Alps (see Table 4.2). 
Table 4.2: Coordinates and distance from Morteratschgletscher of six glaciers, and the correlation coefficient of the measured net mass balance with the modelled net mass balance of Morteratschgletscher (1982-2002).

\begin{tabular}{llll}
\hline Glacier & Coordinates & $\begin{array}{l}\text { Distance from } \\
\text { Morteratsch- } \\
\text { gletscher }(\mathrm{km})\end{array}$ & $R$ \\
\hline Griesgletscher & $46^{\circ} 26^{\prime} \mathrm{N} 8^{\circ} 20^{\prime} \mathrm{E}$ & 123 & 0.59 \\
Silvretta & $46^{\circ} 51^{\prime} \mathrm{N} 10^{\circ} 05^{\prime} \mathrm{E}$ & 51 & 0.91 \\
Hintereisferner & $46^{\circ} 48^{\prime} \mathrm{N} 10^{\circ} 46^{\prime} \mathrm{E}$ & 78 & 0.73 \\
Kesselwandferner & $46^{\circ} 50^{\prime} \mathrm{N} 10^{\circ} 48^{\prime} \mathrm{E}$ & 82 & 0.75 \\
Vernagtferner & $46^{\circ} 53^{\prime} \mathrm{N} 10^{\circ} 49^{\prime} \mathrm{E}$ & 86 & 0.60 \\
Jamtalerferner & $46^{\circ} 52^{\prime} \mathrm{N} 10^{\circ} 10^{\prime} \mathrm{E}$ & 55 & 0.70 \\
\hline
\end{tabular}

Table 4.2 lists the coordinates of the glaciers, the distance to the Morteratschgletscher and the correlation coefficient with the modelled mass balance of Morteratschgletscher. The mass-balance measurements of Silvretta correlates best with the modelled mass balance $(R=0.91)$. This glacier is also closest to Morteratschgletscher. All mass-balance records show a dramatic low net mass balance in 1998. Besides, all measured net balances have a maximum at 1995, except for the simulated mass balance of Morteratschgletscher. This could be explained by large regional differences in snowfall. Laternser and Schneebeli (2003) showed that in the area of Morteratschgletscher, snow depths were $80 \%$ less for 1995 compared to the long-term mean, while in some other parts of the Alps snow depths were $80 \%$ more than normal.

\subsection{AlBEDO PARAMETERISATIONS}

The foregoing results were calculated by using the albedo parameterisation of Oerlemans and Knap (1998), which we call parameterisation (I). In addition, we applied three other common-used parameterisations to simulate the mass balance and its sensitivity to climate change and to investigate any resulting differences. We explain each parameterisation in this section. Table 4.3 at the end of this section gives a summary.

\subsubsection{PARAMETERISATION I}

The albedo parameterisation developed by Oerlemans and Knap (1998) defines glacier albedo, $\alpha^{(i)}$ as a function of snow depth: 


$$
\alpha^{(i)}=\alpha_{\text {snow }}{ }^{(i)}+\left(\alpha_{\text {ice }}-\alpha_{\text {snow }}{ }^{(i)}\right) \exp \left(\frac{-d}{d *}\right)
$$

where $\alpha_{\text {snow }}$ is the albedo of snow, $\alpha_{i c e}$ the albedo of ice, $d$ is the snow depth (mm w.e.) and $d^{*}$ a characteristic snow depth scale (11 mm w.e.). By relating snow albedo to snow depth, one assumes that the underlying ice or debris influences the surface albedo of snow. The snow albedo also depends on the time since the previous snowfall event. The time since the previous snowfall event actually acts as a surrogate variable for the increase in grain size, melt water, and impurity content when snow gets older. The albedo of snow is calculated from:

$$
\alpha_{\text {snow }}^{{ }^{(i)}}=\alpha_{\text {firn }}+\left(\alpha_{\text {frsnow }}-\alpha_{\text {firn }}\right) \exp \left(\frac{s-i}{t *}\right)
$$

where $\alpha_{\text {firn }}$ is the albedo of firn (0.53), $\alpha_{\text {frnnow }}$ is the fresh snow albedo (0.9), s is the time since the previous snowfall event (in days), $i$ is the actual time (in days) and $t^{*}$ is a time scale (21.9 days). When the snow depth is zero, the albedo equals the ice albedo, which is constant in time and space (0.34). The numerical values of the parameters mentioned above were found by Oerlemans and Knap (1998) using a data set from the weather station at M1 of one year (1995/1996) (Figure 4.1). The values of $\alpha_{\text {frsnow }}$ and $d^{*}$ were chosen to fit the measurements at M1 (Klok and Oerlemans, 2002 (Chapter 3)).

\subsubsection{PARAMETERISATION II}

A disadvantage of the preceding parameterisation is that the ice albedo is constant in space, while in reality the ice albedo varies across the glacier due to, for instance, variations in debris concentration. Therefore, we used Landsat TM and ETM+ images to estimate the ice albedo for each grid cell of the mass-balance model. We calculated an average ice albedo from two Landsat scenes (Figure 4.8). We chose 21 August 2000 and 15 September 2000 (Klok et al., 2003 (Chapter 2)) because these images were acquired rather late in the ablation season when a large part of the glacier is free of snow. Grid cells with an albedo greater than 0.5 were assumed to be snow. We assigned a value of 0.4 for the ice albedo to grid cells that were covered by snow at both images or not calculated at all due to shading or too steep slopes. It turned out that the resulting mean ice albedo of the ablation area is about 0.23 , which is much lower than 0.34 used in parameterisation (I). This is mainly due to debris. The glacier tongue is characterised by bands of low albedo at the sides and high albedo at the middle of the glacier tongue, relating to ice with higher and lower debris concentrations (Klok et al., 2003 
(Chapter 2)). In short, parameterisation (II) equals parameterisation (I), but uses an ice albedo that varies in space and is constant in time.

Note that we only used the Landsat images to include the spatial variation in ice albedo. We did not account for the temporal variation in ice albedo, for which a large time series of Landsat images would be required.

Meanwhile, the temporal resolution of useful Landsat images is low, due to the short return period of the satellite and the restriction of cloudless days and days with small solar zenith angles (Klok et al., 2003 (Chapter 2)).

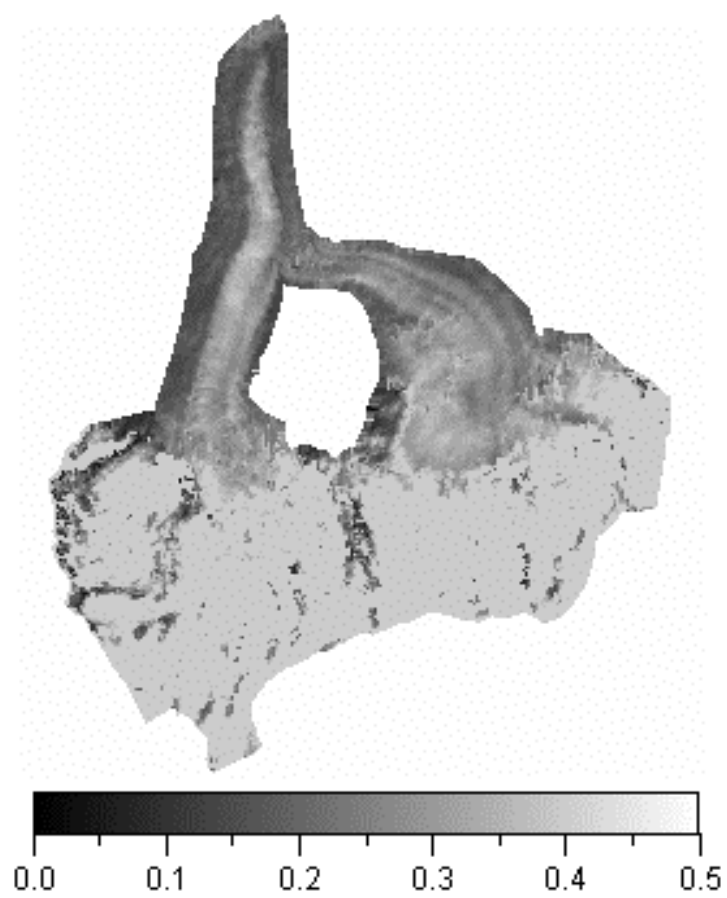

Figure 4.8: Landsat-derived surface ice albedo for Morteratschgletscher.

\subsubsection{PARAMETERISATION III}

In parameterisations (I) and (II), the snow albedo is a function of time since the previous snowfall event. Instead as a function of time, the snow albedo is sometimes presented as a function of the temperature sum since the previous snowfall event (e.g. Winther, 1993; Henneman and Stefan, 1999; Brock et al., 2000). Comparable to time since snowfall as in parameterisations (I) and (II), also the temperature since the previous snowfall event is a proxy for the increase in grain size and impurity content, which leads to lower albedos. Therefore, the third parameterisation uses a temperature sum. It is a combination of the method of Brock et al. (2000), which is based on measurements during an ablation season at Haut Glacier d'Arolla in Switzerland and the parameterisation of Winther (1993), which is based on 
albedo measurements during a winter period at Helligsdaghaugden, a research site in Norway. Brock et al. (2000) calculated albedos for deep snow ( $>0.5 \mathrm{~cm}$ w.e.) and shallow snow ( $<0.5 \mathrm{~cm}$ w.e.), where the surface albedo depends on the accumulated maximum temperature since snowfall. For deep snow, they used a logarithmic function of the accumulated daily maximum temperature $>0{ }^{\circ} \mathrm{C}$. In contrast, Winther (1993) used a linear model and estimated the snow albedo as function of the accumulated maximum temperature in ${ }^{\circ} \mathrm{F}(!)$ and also solar radiation. We found that for deep snow, the albedo was better estimated by the linear model of Winther (1993) than with the method of Brock et al. (2000), as the snow albedo also decays when temperatures are below melting point. However, for our calculations, we did not use the temperature in ${ }^{\circ} \mathrm{F}$ but accumulated daily maximum temperature relative to $-20{ }^{\circ} \mathrm{C}\left(T_{\text {sum }}\right)$. The albedo for shallow snow and the albedos for the transition between deep and shallow snow were calculated according to Brock et al. (2000). The final equations read:

$$
\begin{aligned}
& \alpha_{d s}^{(i)}=0.9-0.000485 * T_{\text {sum }} \\
& \alpha_{s s}^{(i)}=\alpha_{i c e}+0.304 \exp \left(-0.00735 T_{\text {sum }}\right) \\
& \alpha^{(i)}=\left(1-\exp \left(-\frac{d}{24}\right)\right) \alpha_{d s}^{(i)}+\exp \left(-\frac{d}{24}\right) \alpha_{s s}^{(i)}
\end{aligned}
$$

where $\alpha_{d s}$ is the albedo of deep snow and $\alpha_{s s}$ the albedo of shallow snow. For large values of $T_{\text {sum }}$ the albedo of deep snow may decrease to below the albedo of shallow snow. Therefore, ads is constrained by a lower limit that equals $\alpha_{s s}$. The coefficients of Equations (4.3) and (4.4) were found by using data sets of M1, similar to the calibration procedure of parameterisation (I). For the ice albedo, we used the Landsat ice albedo, as with parameterisation (II).

\subsubsection{PARAMETERISATION IV}

Oerlemans and Knap (1998) also investigated the performance of simpler albedo models than parameterisation (I), but concluded that parameterisation (I) performs best. They found a correlation coefficient of 0.93 for modelled and measured surface albedo at M1. However, simulations were not dramatically worse $(\mathrm{R}=0.88)$ for the simplest model, when effects of snow depth and ageing were excluded. Therefore, the fourth parameterisation only uses two values: a constant value for the snow albedo (0.75) and a constant value for the ice albedo (0.34). The ice albedo is 
used when the snow depth is zero, else the surface albedo equals the snow albedo.

Table 4.3: Summary of the albedo parameterisations and change in mass balance $(B)$ due to a perturbation in temperature $(T)$ in $\mathrm{cm}$ w.e. $a^{-1} \mathrm{~K}^{-1}$ and precipitation $(P)$ in $\mathrm{cm}$ w.e. $a^{-1} 10 \%^{-1}$, calculated for each parameterisation from data plotted in Figure 4.10.

\begin{tabular}{lllll}
\hline Parameterisation & Variables & Ice albedo & $d B / d T$ & $d B / d P$ \\
\hline (I) & snow depth, snow age & 0.34 & -59 & 17 \\
(II) & snow depth, snow age & $\begin{array}{l}\text { derived from } \\
\text { Landsat image }\end{array}$ & -62 & 17 \\
(III) & snow depth, & $\begin{array}{l}\text { derived from } \\
\text { temperature sum }\end{array}$ & -62 & 17 \\
(IV) & - & 0.34 & -52 & 14 \\
\hline
\end{tabular}

\subsection{RESULTS FROM DIFFERENT ALBEDO PARAMETERISATIONS}

\subsubsection{MASS BALANCE}

Figure 4.9 shows the modelled net mass balance between 1982 and 2002 for the different albedo parameterisations. The mean net mass balance over 1982-2002 is $-76,-94,-92$ and $-95 \mathrm{~cm}$ w.e. for parameterisation I, II, III and IV respectively. When a matrix of correlation coefficients is calculated, the simplest parameterisation (IV) appears to deviate most. Results of parameterisation (I), (II) and (III) correlate well due to a variable snow albedo, although the use of the Landsat ice albedo leads to more ablation and a lower net mass balance. This is caused by the low mean ice albedo of the ablation area (0.23) derived from the Landsat images compared to 0.34 used in parameterisation (I). It is, however, questionable if the simulated melt rates at the sides of the glacier tongue are realistic when the Landsat ice albedo is used. The very low albedos at these locations are a result of high debris concentrations, which also cause an insulating effect and this impedes the melt-enhancing effect of a low albedo. However, the massbalance model does not take this insulating effect into account.

\subsubsection{MASS-BALANCE SENSITIVITY}

Even if the mean ablation is similar for different albedo parameterisations, one cannot be sure that the sensitivity is similar as well. For this reason, we also tested the mass-balance sensitivity to a change in climate for the four albedo parameterisations. 


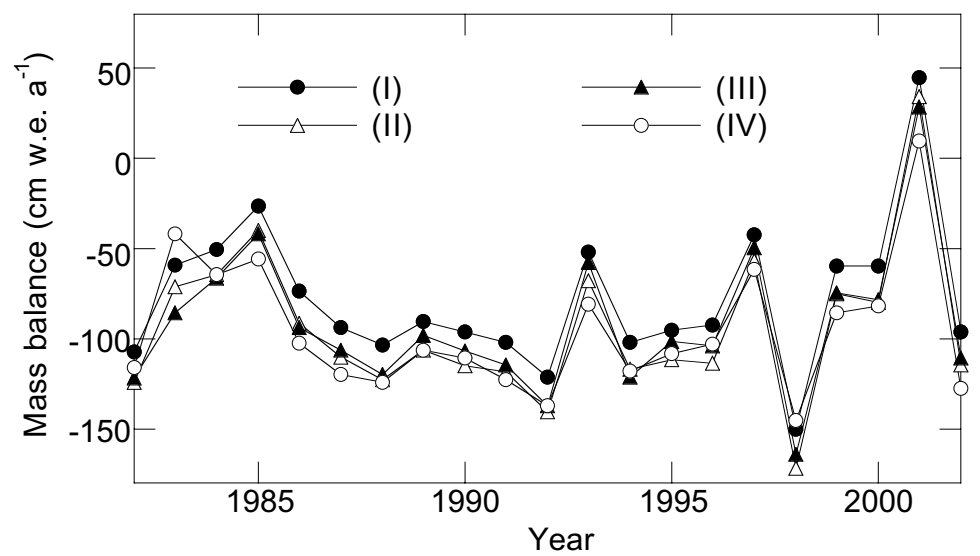

Figure 4.9: Simulated net mass balance from four different albedo parameterisations.
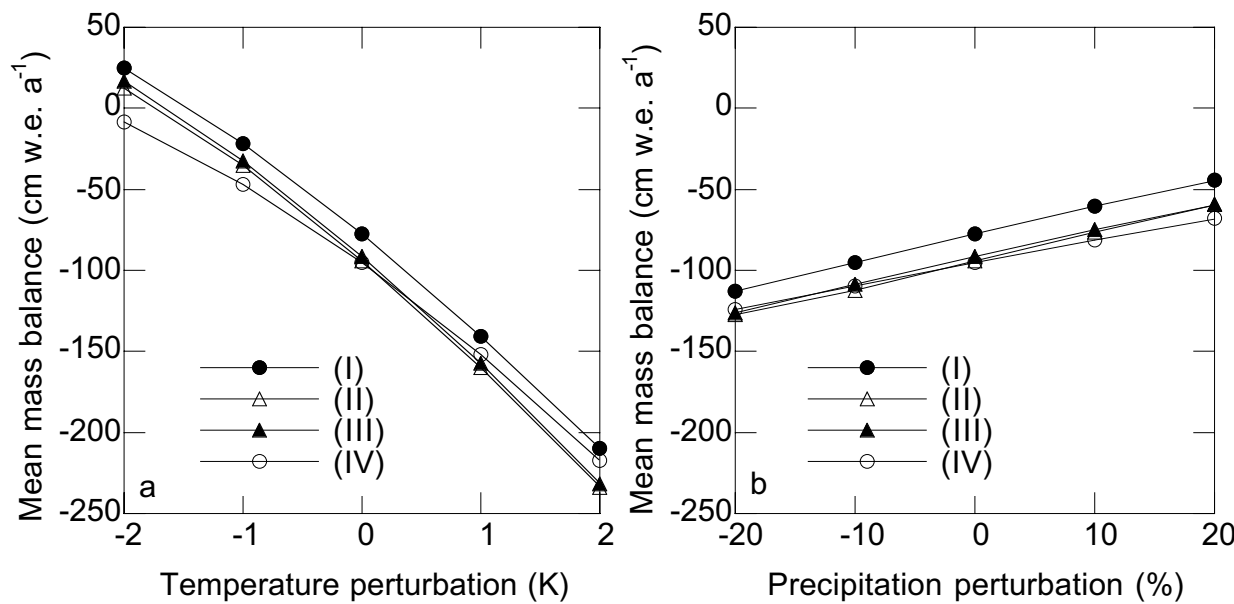

Figure 4.10: Change in the mean net mass balance (1982-2002) of

Morteratschgletscher for perturbations in air temperature (a) and precipitation (b) calculated from four different albedo parameterisations.

We defined mass-balance sensitivity as the change in the mean net mass balance over 1982-2002 due to a perturbation in the climate. We only investigated the mass-balance sensitivity to air temperature and precipitation (Figure 4.10 and Table 4.3). Generally, the results do not differ much for the four albedo parameterisations. The mass-balance sensitivity to a change in temperature is greatest for parameterisations (II) and (III), which use ice albedos derived from Landsat images. Parameterisation (IV) shows the lowest sensitivity because it does not account for the decrease in snow albedo when snow gets older or the snow pack gets thinner, meaning that the albedo feedback regarding snow is not fully covered. Besides, the 
ice albedo of parameterisation (IV) is greater than the average Landsatderived ice albedo. This implies a smaller difference between the albedos of snow and ice, causing a smaller albedo feedback when the period of exposed ice increases and thus a lower sensitivity. This also explains the difference between parameterisation (I) and (II). Hence, the average lower albedo rather than the spatial distribution of the Landsat-derived ice albedo is the reason for the larger sensitivity of parameterisation (II) compared to (I).

Figure 4.11 shows how the mass-balance sensitivity varies with elevation. The sensitivity is lower in the accumulation area because the albedo feedback is smaller. Namely, in the accumulation area, a change in temperature or precipitation only influences the snow albedo and does not result in a change in the duration of the period of exposed ice.

Parameterisation (IV) leads to sensitivities that, at all elevations, are smaller than the results of the other parameterisations.

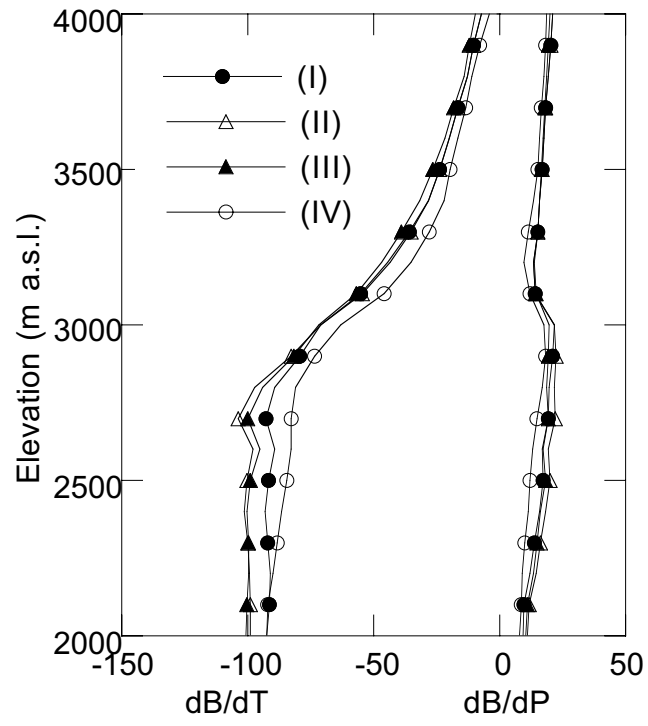

(cm w.e. $\left.\mathrm{a}^{-1} \mathrm{~K}^{-1}\right) \quad\left(\mathrm{cm}\right.$ w.e. $\left.\mathrm{a}^{-1} 10 \%^{-1}\right)$

Figure 4.11: Climate sensitivity with regard to perturbations in air temperature and precipitation as function of elevation, as calculated from four different albedo parameterisations.

\subsection{DISCUSSION}

The mass-balance sensitivities to perturbations in air temperature and precipitation as calculated from different albedo parameterisations confirm that when ageing of snow is taken into account, the mass-balance sensitivity 
increases (Table 4.3). Using a Landsat-derived ice albedo for each grid cell, instead of using a constant value for the entire ablation area, increases the mass-balance sensitivity to temperature. This is not due to the spatial variation of the surface albedo, but is associated with the fact that the mean ice albedo derived from the Landsat images is smaller $(\sim 0.23)$ than the constant ice albedo that is used (0.34).

However, the differences between the results of the different albedo parameterisations are not large. The mass-balance sensitivity to temperature as derived from the most comprehensive parameterisations (II and III) is only $19 \%$ larger than the simplest parameterisation (IV). This is in agreement with the results of De Ruyter de Wildt and Oerlemans (2003) mentioned in the introduction. Using Landsat-derived ice albedos instead of a constant ice albedo causes an increase in the mass-balance sensitivity of $5 \%$. Differences between parameterisation (II) and (III) are negligible. The results indicate that for an accurate estimate of the mass-balance sensitivity, the albedo parameterisation should capture the snow albedo decrease when the snow pack gets older or thinner. The snow albedo can be either modelled as function of snow age or as function of the accumulated daily maximum temperatures since the previous snowfall event.

Although this research indicates that the sensitivity of the massbalance to a change in climate is influenced little by the type of albedo parameterisation, we underline that small changes in surface albedo could still lead to large changes in calculated melt rates. These changes can be of similar magnitude as a warming of $1{ }^{\circ} \mathrm{C}$ would cause (Oerlemans and Hoogendoorn, 1989; and Oerlemans, 1992). Therefore, for an accurate calculation of surface melt rates it is important to use albedo parameterisations that capture the spatial and temporal albedo variations well.

A type of albedo parameterisation that we did not include in this research is one in which the ice albedo increases with elevation. Oerlemans (1991) related the ice albedo to the distance from the equilibrium line altitude (ELA) because, so he argued, on many glaciers the amount of accumulated dust, soot, and liquid water increases when going downglacier. This parameterisation thus calculates the lowest albedos for the glacier terminus. It also captures the process that retreating glaciers become often more heavily debris-covered, resulting in lower ice albedos because glacier retreat is related to an increase in the ELA. However, Landsat images revealed that the ice albedo of Morteratschgletscher is not clearly a function of elevation (Klok et al., 2003 (Chapter 2)). For this reason, we did not use this parameterisation to Morteratschgletscher, but it might be applicable for other glaciers. The mass-balance sensitivity calculated from this parameterisation would likely be larger than the sensitivities calculated from parameterisations I to IV because of the dependence of the ice albedo on the ELA. It causes an albedo feedback that results in a greater massbalance sensitivity. 
Acknowledgements - We are grateful to Roderik van de Wal for his helpful comments on this research. We thank Angie Souren for improving the English, and Meteo Schweiz for providing the meteorological data.

\section{REFERENCES}

Arnold, N.S.I., Willis, I.C., Sharp, M.J., Richards, K.S. and Lawson, W.J. 1996. A distributed surface energy-balance model for a small valley glacier, I, Development and testing for Haut Glacier d'Arolla, Valais, Switzerland. Journal of Glaciology, 42(140), 77-89.

Brock, B.W., Willis, I.C. and Sharp, M.J. 2000. Measurements and parameterisation of albedo variations at Haut Glacier d'Arolla, Switzerland. Journal of Glaciology, 46(155), 675-688.

De Ruyter de Wildt, M.S. and Oerlemans, J. 2003. A calibrated mass balance model for Vatnajökull, Iceland. Jökull, in press.

Greuell, W. and Böhm, R. 1998. 2 m temperatures along melting mid-latitude glaciers, and implications for the sensitivity of the mass balance to variations in temperature. Journal of Glaciology, 44(146), 9-20.

Henneman, H.E. and Stefan, H.G. 1999. Albedo models for snow and ice on a freshwater lake. Cold Regions Science and Technology, 29, 31-48.

Jóhannesson, T., Sigurdsson, O., Laumann ,T. and Kennet, M. 1995. Degree-day glacier mass balance modelling with applications to glaciers in Iceland, Norway and Greenland. Journal of Glaciology, 41(138), 345-358.

Kayastha, R.B., Ohata, T. and Ageta, Y. 1999. Application of a mass-balance model to a Himalayan glacier. Journal of Glaciology, 45(151), 559-567.

Klok, E.J. and Oerlemans, J. 2002. Model study of the spatial distribution of the energy and mass balance of Morteratschgletscher, Switzerland. Journal of Glaciology, 48(163), 505-518.

Klok, E.J., Greuell, W. and Oerlemans, J. 2003. Temporal and spatial variation of the surface albedo of Morteratschgletscher, Switzerland, as derived from 12 Landsat images. Journal of Glaciology, accepted.

Laternser, M. and Schneebeli, M. 2003. Long-term snow climate trends of the Swiss Alps (1931-99). International Journal of Climatology, 23, 733-750.

Munro, D.S. 1991. A surface energy exchange model of glacier melt and net mass balance. International Journal of Climatology, 11, 689-700.

Oerlemans, J., and Hoogendoorn, N.C. 1989. Mass-balance gradients and climatic change. Journal of Glaciology, 35(121), 399-405.

Oerlemans, J. 1991. A model for the surface mass balance of ice masses: part I. Alpine glaciers. Zeitschrift für Gletscherkunde und Glazialgeologie, 27/28, 63-83.

Oerlemans, J. 1992. Climate sensitivity of glaciers in southern Norway: applications of an energy-balance model to Nigardsbreen, Hellstugubreen and Alfotbreen. Journal of Glaciology, 38(129), 223-232.

Oerlemans, J. and Knap, W.H. 1998. A 1 year record of global radiation and albedo in the ablation zone of Morteratschgletscher, Switzerland. Journal of Glaciology, 44(147), 231-238.

Oerlemans, J. and Grisogono, B. 2002. Glacier wind and parameterisation of the related surface heat flux. Tellus, A 54, 440-452. 
Oerlemans, J. and Klok, E.J. 2002. Energy balance of a glacier surface: analysis of AWS data from the Morteratschgletscher, Switzerland. Arctic, Antarctic and Alpine Research, 34(123), 115-123.

Vallon, M., Vincent, C. and Reynaud, L. 1998. Altitudinal gradient of mass-balancesensitivity to climatic change from 18 years of observations on glacier d'Argentière, France. Journal of Glaciology, 44(146), 93-96.

Van de Wal, R.S.W., Oerlemans, J. and Van der Hage, J.C. 1992. A study of ablation variations on the tongue of Hintereisferner, Austrian Alps. Journal of Glaciology, 38(130), 319-324.

Winther, J.G. 1993. Short- and long-term variability of snow albedo. Nordic Hydrology, 24, 199-212. 


\section{Climate ReCONSTRUCTIONS DeRIVED FROM GLOBAL GLACIER LENGTH RECORDS INCLUDING A CASE-STUDY FOR EUROPEAN} GLACIERS $^{*}$

Abstract - Glaciers have fluctuated in historic times and the length fluctuations of many glaciers are known. From these glacier length records, a climate reconstruction described in terms of a reconstruction of the equilibrium line altitude (ELA) or the mass balance can be extracted. In order to derive a climate signal from numerous glacier length records, a model is needed that takes into account the main characteristics of a glacier, but uses little information about the glacier itself. Therefore, a simple analytical model was developed based on the assumption that the change in glacier length can be described by a linear response equation. The model takes into account the geometry of the glacier, the length response time and the mass balance - surface elevation feedback. The model was tested on seventeen European glacier length records. The results revealed that the ELA of these glaciers increased on average $54 \mathrm{~m}$ between 1920 and 1950. The results were compared to mass balance reconstructions calculated with a numerical flowline model and derived from historical temperature and precipitation records. The findings indicate that the analytical model is useful to gain information about historical mass balance rates and ELAs. Then, we derived historic fluctuations in the ELA on the basis of nineteen glacier length records from different parts of the world. The results show that all glaciers of this global data set experienced an increase in the ELA between 1900 and 1960 . Between 1910 and 1959, the average increase was $33 \pm 8 \mathrm{~m}$. This implies that during the first half of the twentieth century, the climate was warmer or drier than before. The ELAs decreased to lower elevations after around 1960 up to 1980, when most of our ELA reconstructions end. These results can be translated into a global temperature increase of $0.8 \pm 0.2 \mathrm{~K}$ and a sea level rise of 0.3 $\mathrm{mm} \mathrm{a}^{-1}$ for the period $1910-1959$.

\footnotetext{
"Based on: Klok, E.J. and Oerlemans, J. 2003. Deriving historical equilibrium-line altitudes from a glacier length record by linear inverse modelling. The Holocene, 13(3), 343-351; and Klok, E.J. and Oerlemans, J. 2003. Climate reconstructions derived from global glacier length records. Arctic, Antarctic and Alpine Research, submitted.
} 


\subsection{INTRODUCTION}

Glacier length records contain information on how climate has changed. This information often complements historical meteorological data, as glacier length records generally extend further back in time. Besides, glacier records are often from remote areas and higher altitudes, for which meteorological data are scarce (IPCC, 2001). Hence, glacier length records form an alternative method for climate reconstruction for periods and locations for which instrumental or proxy indicators are inadequate or contradicting. Extracting climatic information from glacier length records implies inverse modelling. Normally, the climate signal extracted from length records is represented as a mass-balance history or as a reconstruction of the equilibrium line altitude (ELA). ELA reconstructions resemble transient climate changes more properly than glacier length changes, as the glacier length is subject to the length response time and the sensitivity of a glacier.

Callendar (1950) was probably the first who attempted to extract a climate signal from the dimensions of a glacier. He presented a relation between the height of the firn line and the glacier length, including the width at the glacier snout, the glacier width and slope at the firn line altitude and a constant ratio between the accumulation and ablation area. Other simple methods to reconstruct the ELA are (I) the median elevation of a glacier (Manley, 1959), which is the elevation midway between the glacier snout and the base of the headwall, (II) the THAR (Toe-to-Headwall Altitude Ratio), which is a fraction of the height range of the glacier (Meierding, 1982), and (III) the ratio of the accumulation area to the total area (AAR) (Porter, 1975). Benn and Lehmkuhl (2000) discussed the applicability of these and other commonly used methods for different glacier types. Haeberli and Hoelzle (1995) developed a simple parameterisation scheme, build on four geometric parameters (glacier length and area, minimum and maximum elevation). They reconstructed changes in the mass balance of glaciers in the European Alps.

However, none of the methods above considers the response time of a glacier. Nye (1965) was the first who used a numerical method to infer the mass-balance history of a glacier from its length fluctuations. Oerlemans (1997), Wallinga and Van de Wal (1998) and Mackintosh and Dugmore (2000) used a numerical flowline model and the procedure of dynamic calibration to derive a mass-balance history. The advantage of a numerical flowline model is that the geometry, the climate sensitivity and the response time of each particular glacier are taken into account. However, numerical flowline models need lots of information, which is not always available. Therefore, they cannot be applied to a large number of glacier records. 


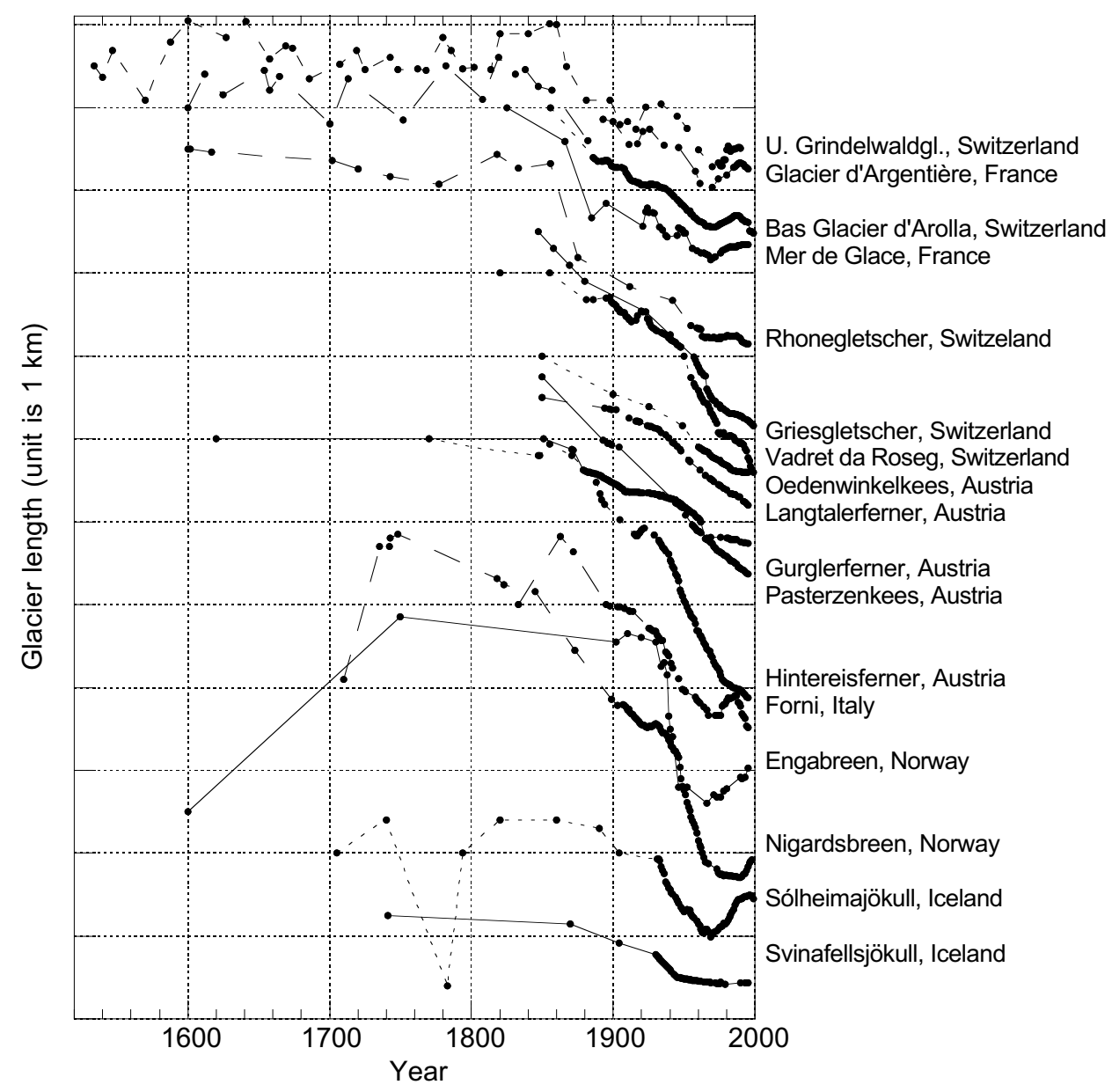

it takes the response time and the geometry of the glacier as well as the mass balance-surface height feedback into account. The model is described in Section 5.2.

As accurate model input data, for instance on the glacier geometry or the mass-balance regime, is not available for some glaciers, we investigated 
the effects of the uncertainties in the input data on the ELA reconstruction. This sensitivity study is presented in Section 5.3.

As a start, we performed a case study and tested the analytical model for seventeen European glaciers, the length records of which are shown in Figure 5.1. At the top of the graph, glaciers from the western Alps are shown, followed by glaciers from the eastern Alps, Scandinavia and Iceland. These seventeen glaciers, which all retreated between 1850 and 1980, were selected because their length records are among the longest of all European glacier records. We calculated reconstructions of the mass balance and ELA with the analytical model and compared the results with climate reconstructions derived from other methods (Section 5.4).

We then extended this investigation to global glacier length changes and derived historic fluctuations in the equilibrium line altitude (ELA) on the basis of nineteen glacier length records from different parts of the world. So far, the climatic interpretation of worldwide glacier length fluctuations has been studied occasionally. More frequently, length fluctuations of single glaciers or glaciers in one specific region were investigated, e.g. the European Alps (Haeberli and Hoelzle, 1995), the Central Italian Alps (Pelfini and Smiraglia, 1997), Scandinavia (Bogen et al., 1989), the Patagonian Ice Fields (Warren and Sugden, 1993; Aniya, 1999), the North Cascade glaciers (Pelto and Hedlund, 2001), Northern Eurasia (Solomina, 2000), Tien Shan (Savoskul, 1997), New Zealand (Chinn, 1996) and the tropics (Kaser, 1999). On the other hand, Oerlemans (1994) compared the retreat of 48 glaciers from different regions of the world. He estimated from this a global linear warming trend of $0.66 \mathrm{~K}$ per century, but did not take the response time of the glaciers into account. Hoelzle et al. (2003) also investigated 90 glaciers worldwide. They estimated -from cumulative glacier length changes- a global mean specific mass balance of $-0.25 \mathrm{~m}$ w.e. $\mathrm{a}^{-1}$ since 1900 . The analytical model that we used for the climatic interpretation of length fluctuations is more sophisticated than the models of Oerlemans (1994) and Hoelzle et al. (2003), as we corrected for the length response time and treated the geometry of each glacier more comprehensively.

In Section 5.5, we describe the nineteen glaciers of our global data set. The ELA and mass-balance reconstructions derived from the length records are presented in Section 5.6. The results are also interpreted in terms of changes in air temperature (Section 5.6.4). Section 5.7 contains a discussion of the results and Section 5.8 a summary. 


\subsection{THE ANALYTICAL MODEL}

\subsubsection{LINEAR RESPONSE EQUATION}

A glacier responds to a change in the mass balance (and the ELA) by changing its length. The size of the length change depends on several factors, such as the geometry, the slope and the mass-balance profile of the glacier. For relatively small length fluctuations compared to the total glacier length, it is assumed that the change in glacier length can be described by a linear response equation:

$$
\frac{d L^{\prime}(t)}{d t}=-\frac{c E^{\prime}(t)+L^{\prime}(t)}{t_{r L}}
$$

where $L^{\prime}(t)$ is the glacier length with regard to a reference length $\left(L_{0}\right)(\mathrm{m}), t$ is time (a), $c$ is the climate sensitivity $(-), E^{\prime}(t)$ is the ELA with regard to a reference altitude $\left(E_{0}\right)(\mathrm{m})$ and $t r_{L}$ is the length response time of the glacier (a) (see Figure 5.2 for explanation of the symbols). The concept of this analytical model was first put forward by Oerlemans (2001).

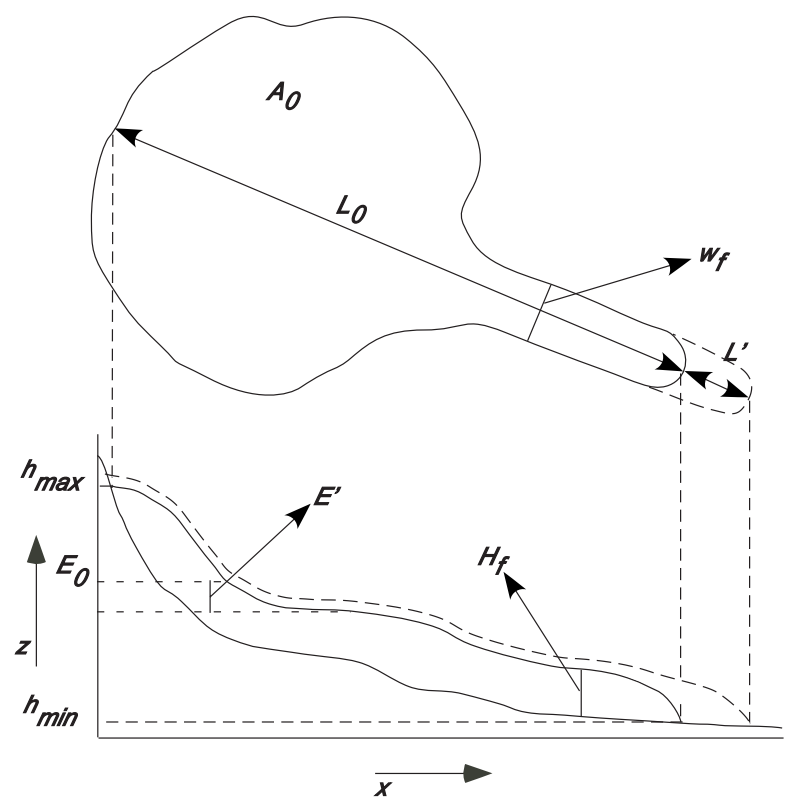

Figure 5.2: Schematic outline of a glacier, showing some of the parameters of the analytical model.

The reference length, $L_{0}$, is calculated as the mean of a glacier length record. The climate sensitivity $(c)$ is a factor that relates a change in the 
glacier's steady-state length to a change in the ELA. For large length fluctuations, the analytical model is not valid because the glacier geometry can change significantly when the glacier retreats or advances over a large distance. As a result, the response time and the climate sensitivity cannot be kept constant.

The inverse of the linear response equation can be used to calculate the historic ELAs:

$$
E^{\prime}(t)=-\frac{1}{c}\left(L^{\prime}+t_{r L} \frac{d L^{\prime}}{d t}\right)
$$

If $E^{\prime}(t)$ is multiplied by the mass-balance gradient at the equilibrium line altitude $\left(\beta_{E}\right)$, this equation can be used to calculate a mass-balance reconstruction $\left(B^{\prime}(t)\right)$. Methods to estimate the length response time and the climate sensitivity are given in Section 5.2.2. First, how the time derivative of a length record can be calculated is described.

Generally, glacier length records are not smooth records (see Figure 5.1). Linear interpolation between the observed data points is applied, assuming that the glaciers have not fluctuated substantially during the periods between these points. It is likely that they were not larger during the period in between the data points, otherwise moraines would have been deposited. However, glaciers could have been smaller during these periods. Taking the time derivative from these length records, which are needed for Equation (5.2), is not a straightforward exercise because the derivatives will be discontinuous at the data points. To obtain smooth time derivatives, we tried to fit polynomials to the length records and to calculate the time derivative of these polynomials. However, we found that not every length record can be represented well by a polynomial fit of a certain degree. We then used Fourier functions to describe the length records and calculate the time derivatives. The advantage of Fourier series is that this method allows separation of time scales. Nevertheless, most length records only show a retreat in length and little fluctuations. The results revealed that these length records especially are difficult to describe by Fourier decompositions. The use of cubic spline interpolation leads to smooth length records. However, this method often causes an increase in the maxima of the length records and was therefore rejected.

We concluded that a better solution would be to apply a Gaussian filter to the length records and to calculate the time derivatives with central differences. A Gaussian filter is a weighted average, and the weight for each year $\left(w_{i}\right)$ is defined by a Gaussian function. The filtered length record $L^{\prime}(t)$ can be calculated with: 


$$
L^{\prime}(t)=\frac{\sum_{-N}^{N} w_{i} \Lambda^{\prime}(t+i)}{\sum_{-N}^{N} w_{i}}
$$

where $\Lambda^{\prime}(t)$ is the original length record, as shown in Figure 5.1. The Gaussian function is defined as:

$$
w_{i}=e^{-i^{2} / \tau^{2}}
$$

where $\tau$ is the timescale. As we concentrated on fluctuations in the ELA occurring on a decadal timescale, the timescale of the Gaussian filter was taken as 10 years. Accordingly, $N$ was taken as 15 years. Figure 5.3 gives an example of the filtered length record and its time derivative of Hintereisferner. The time derivative does not show any discontinuities at the data points.

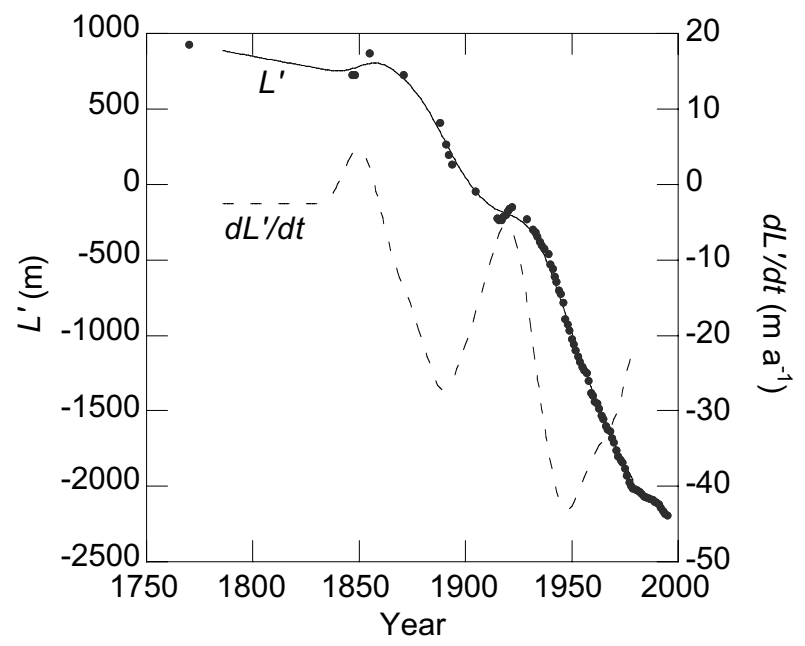

Figure 5.3: The length record of Hintereisferner filtered with the Gaussian filter and the time derivative of the length record (dashed line). The black dots indicate the individual data points.

\subsubsection{CALCULATION OF THE LENGTH RESPONSE TIME AND THE CLIMATE SENSITIVITY}

The length response time and the climate sensitivity of a glacier can be determined by a numerical flowline model, as done previously for Hintereisferner (Greuell, 1992), Pasterzenkees (Zuo and Oerlemans, 1997a), Unterer Grindelwaldgletscher (Schmeits and Oerlemans, 1997), Rhonegletscher (Wallinga and Van de Wal, 1998), Nigardsbreen (Oerlemans, 1997), Glacier 
d'Argentière (Huybrechts et al., 1989) and Sólheimajökull (Mackintosh, 2000). However, we prefer a simpler method based on a perturbation analysis on the continuity equation (Oerlemans, 2001). After Reynolds decomposition and neglecting higher-order terms of the continuity equation for a glacier volume, a perturbation equation is obtained:

$$
\frac{d V^{\prime}}{d t}=\overline{H_{0}} \frac{d A^{\prime}}{d t}+A_{0} \frac{d \overline{H^{\prime}}}{d t}
$$

where $V^{\prime}$ is the glacier volume with regard to the reference volume $\left(\mathrm{m}^{3}\right), \overline{H^{\prime}}$ is the mean glacier thickness with regard to the reference thickness $\left(\overline{H_{0}}\right)$ $(\mathrm{m})$, and $A^{\prime}$ is the glacier area with regard to the reference area $\left(A_{0}\right)\left(\mathrm{m}^{2}\right)$. The reference situation of the glacier is thus defined by $L_{0}$ and $A_{0}$. According to Equation (5.5), a change in glacier volume is directly coupled to a change in the area and the thickness of a glacier.

It is assumed that a change in the glacier area is only related to a glacier length fluctuation. The corresponding volume change is then calculated by multiplying the length change by the width and the thickness of the glacier tongue. The width of the glacier tongue is assumed to be constant. If we also assume that the change in glacier thickness is proportional to the change in glacier length, the volume change of a glacier can be written as:

$$
\frac{d V^{\prime}}{d t}=\left(w_{f} H_{f}+\eta A_{0}\right) \frac{d L^{\prime}}{d t}
$$

where $\eta$ is a constant that relates the mean glacier thickness to the glacier length, $w_{f}$ is the characteristic width $(\mathrm{m})$ and $H_{f}$ the characteristic thickness of the glacier tongue $(\mathrm{m})$ (see Figure 5.2).

Changes in the glacier volume are caused by changes in the mass balance, described by:

$$
\frac{d V^{\prime}}{d t}=A_{0} B^{\prime}+A_{0} \beta \overline{H^{\prime}}+w_{f} B_{f} L^{\prime}
$$

The first term on the right hand side is the volume change caused by a perturbation of the mass-balance rate, $B^{\prime}(\mathrm{m})$. $B^{\prime}$ can be expressed in a change in the ELA $\left(E^{\prime}\right)$ by dividing $B^{\prime}$ by the mass-balance gradient at the equilibrium line altitude $\left(\beta_{E}\right)$. The second term is a volume change resulting from the feedback between the mass balance and the surface elevation of the glacier. $\beta$ is the average mass-balance gradient over the glacier and $\overline{H^{\prime}}$ can be described as $\eta L^{\prime}$. The last term represents a volume change due to a 
change in glacier length, where $B_{f}$ is the melt rate at the glacier terminus (m). Combining and rewriting Equation (5.6) and (5.7) yields:

$$
\frac{d L^{\prime}}{d t}=\frac{\beta_{E} A_{0}}{\eta A_{0}+w_{f} H_{f}} E^{\prime}+\frac{\eta \beta A_{0}+w_{f} B_{f}}{\eta A_{0}+w_{f} H_{f}} L^{\prime}
$$

Comparing this equation with Equation (5.1), the length response time and the climate sensitivity can be derived:

$$
\begin{aligned}
& t_{r L}=-\frac{\eta A_{0}+w_{f} H_{f}}{\eta \beta A_{0}+w_{f} B_{f}} \\
& c=\frac{\beta_{E} A_{0}}{\eta \beta A_{0}+w_{f} B_{f}}
\end{aligned}
$$

We calculated the climate sensitivity and the length response time of each glacier with these equations. It should be noted that Equation (5.9), the expression for the length response time, also holds for the volume response time because volume and length changes are coupled (Equation (5.6)). Normally, the volume response time is shorter than the length response time because the glacier volume is more directly affected by changes in the mass balance (Oerlemans, 1997). Therefore, length response times calculated with Equation (5.9) are expected to be shorter than the real length response times.

If the mass balance - surface elevation feedback is not taken into account (i.e. $\boldsymbol{\eta}=0$ ), the length response time (Equation (5.9)) corresponds to the volume time scale derived by Jóhannesson et al. (1989). The volume time scale of Jóhannesson is always shorter than the length response time calculated with Equation (5.9). Furthermore, the climate sensitivity decreases if the mass balance - surface elevation feedback is discounted. If we also assume that the glacier's width is constant along the glacier, the climate sensitivity corresponds to the often-used expression reported in Paterson (1994):

$$
\frac{d L^{\prime}}{d B^{\prime}}=\frac{L_{0}}{B_{f}}
$$

However, most glaciers do not have a uniform width. Normally, the glacier tongue is narrower than the mean glacier width. In that case, Equation (5.11) underestimates the climate sensitivity. 
We obtained most input data to run the model from Haeberli et al. (1998) and from topographical maps. $\beta_{E}$ and $\beta$ were calculated from massbalance measurements. However, mass-balance measurements were not available for all glaciers, and if absent, the mean of the mass-balance gradients of nearby glaciers was used. The thickness of the glacier snout $\left(H_{f}\right)$ was derived from glacier slope and length. If we assume a constant driving stress, the ice thickness at any point on the glacier can be calculated from the surface slope (Paterson, 1994). The surface slope multiplied by the glacier thickness is then a constant, and the thickness of the glacier snout follows:

$$
H_{f}=\frac{\bar{H} \cdot s}{s_{f}}
$$

where $s_{f}$ is the surface slope at the glacier snout, estimated from a topographical map, and $s$ is the average surface slope of the glacier. We derived $s$ from the maximum elevation, the minimum elevation and the length of the glacier. $\bar{H}$ is the mean glacier thickness, which we calculated from an expression proposed by Oerlemans (2001):

$$
\bar{H}=\left(\frac{\mu L}{1+v_{S}}\right)^{1 / 2}
$$

where $L$ is the glacier length $(\mathrm{m})$ and $m$ and $n$ are constants $(\sim 9 \mathrm{~m}$ and $\sim 30$ respectively) determined by a numerical model (Oerlemans, 2001). Taking the derivative of Equation (5.13) yields an expression for $\eta$ :

$$
\eta=\frac{d \bar{H}}{d L}=\frac{1}{2}\left(\frac{\mu}{(1+v s) L}\right)^{1 / 2}
$$

A typical value for $\eta$ is 0.006 .

This analytical model thus takes into account the length response time of the glacier. This implies that the ELA reconstruction shifts backward in time as the length response time increases, which also influences the amplitude of the ELA fluctuations. The geometry of the glacier is included in the model, mainly defined by the width of the glacier tongue and the glacier area. Glaciers with relatively small glacier tongues compared to the total surface area will therefore have larger climate sensitivities and response times. Furthermore, the effect of the mass balance - surface elevation feedback is included. For steep glaciers, $\eta$ is small (the surface elevation changes little when the glacier length changes), implying a weak 
mass balance - surface elevation feedback, resulting in shorter length response times and lower climate sensitivities.

\subsection{PARAMETER SENSITIVITY}

Climate sensitivity and length response time are determined by eight parameters. These parameter values may contain errors because some of them are unknown or difficult to estimate. We therefore investigated the effect of a change in these parameters on length response time and climate sensitivity and, finally, on the ELA reconstruction of a fictitious glacier. Table 5.1 lists the parameter values of this fictitious glacier. The values are supposed to represent an average valley glacier and lead to a length response time of 85 years and a climate sensitivity of 70 .

Table 5.1: Parameters of the fictitious glacier.

\begin{tabular}{ll}
\hline Parameter & Value \\
\hline$L_{0}$ & $15 \mathrm{~km}$ \\
$A_{0}$ & $20 \mathrm{~km}^{2}$ \\
$s$ & $10^{\circ}$ \\
$s_{f}$ & $10^{\circ}$ \\
$w_{f}$ & $500 \mathrm{~m}$ \\
$B_{f}$ & $-5 \mathrm{~m} \mathrm{w}$.e. $\mathrm{a}^{-1}$ \\
$\beta$ & $0.005 \mathrm{~m}$ w.e. $\mathrm{a}^{-1} \mathrm{~m}^{-1}$ \\
$\beta_{E}$ & $0.007 \mathrm{~m}$ w.e. $\mathrm{a}^{-1} \mathrm{~m}^{-1}$ \\
\hline
\end{tabular}

We changed each of these parameters by $30 \%$. The resulting length response times and climate sensitivities are plotted in Figure 5.4. They aremost sensitive to changes in the melt rate at the glacier terminus, the width of the glacier tongue and the mass-balance gradient at the equilibrium line altitude. Also, the glacier area seems to influence the value of $t r_{L}$ and $c$ substantially. Nevertheless, we do not expect the surface area to be an important contributor to the uncertainties in $t_{L}$ and $c$, as it is often known within $10 \%$. An increase in the melt rate at the glacier tongue or an increase in its width both lead to shorter response times, as both of them cause a larger mass turnover. However, an increase in the width of the glacier tongue also implies that more ice needs to be transported down the glacier to make up for an equal change in glacier length. This counterbalances the effect of a larger mass turnover on $t r_{L}$. Therefore, the length response time is more sensitive to melt rate than to width of the glacier tongue. Regarding climate sensitivity, changes in glacier width or melt rate at the glacier terminus lead to the same effect. Generally, $t r_{L}$ and $c$ change into the same direction when one of the input parameters is varied. 

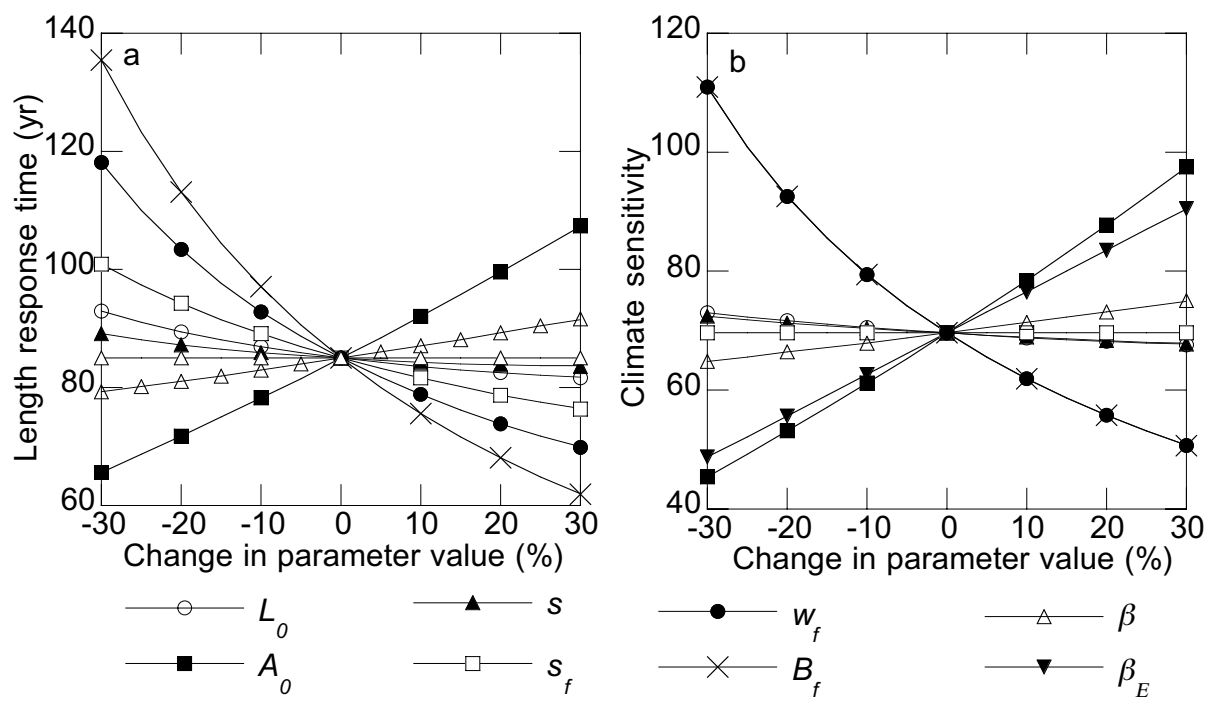

Figure 5.4: Length response time (a) and climate sensitivity (b) as function of a change in the input parameters. In $(a), B_{f}$ and $w_{f}$ coincide. ( $L_{0}$ : reference glacier length, $A_{0}$ : reference glacier area, s: mean surface slope, $s_{f}$ surface slope of the glacier snout, $w_{f}$ : width of glacier tongue, $B_{f}$; melt rate at the glacier terminus, $\beta_{E}$ : mass-balance gradient at the ELA, $\beta$ : mass-balance gradient of the glacier).

As a second step, we determined the effect of a change in length response time and climate sensitivity on the ELA reconstruction of this fictitious glacier. We derived historic ELAs from a (fictitious) length record, which we defined as a sine function with an amplitude $\left(L^{\prime}{ }_{\text {max }}\right)$ of $1.5 \mathrm{~km}$ and a period $(P)$ of 300 years. Instead of smoothing this record with a Gaussian filter and calculating the derivatives with central differences, we directly inserted this function and its time derivative in Equation (5.2). This leads to:

$$
E^{\prime}(t)=-\lambda \sin \left(2 \pi \frac{t+\varphi}{P}\right)
$$

where $\lambda$ and $\varphi$ are the amplitude and the phase difference of the ELA reconstruction (see Figure 5.5) and are described by:

$$
\lambda=\frac{1}{c} \sqrt{1+\left(2 \pi \frac{t r_{L}}{P}\right)^{2}} L_{\text {max }}^{\prime}
$$




$$
\varphi=\frac{1}{4} P-\frac{P}{2 \pi} \arctan \left(\frac{P}{2 \pi t r_{L}}\right)
$$

Figure 5.5 shows the length and the reconstructed ELA as function of time. The amplitude of the ELA reconstruction thus depends on the period of the length record, the length response time and the climate sensitivity. The reconstruction experiences a phase difference depending on the length response time. For very large length response times, the phase difference approaches $0.25 P$.

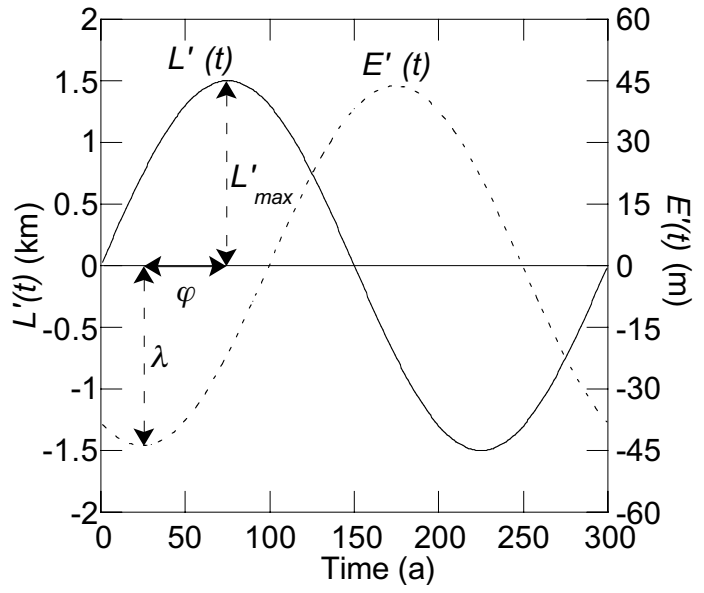

Figure 5.5: Length record and reconstructed ELAs of the fictitious glacier. The length response time is 85 years and the climate sensitivity 70 .

We varied the length response time between 65 and 123 years and the climate sensitivity between 53 and 101 . These numbers are the limits set by a change of $25 \%$ (plus or minus) in the most sensitive parameter, $B_{f}$ (Figure 5.4). The effects on the amplitude and phase difference of the ELA reconstruction are plotted in Figure 5.6. The amplitude varies roughly from 30 to $59 \mathrm{~m}$ and the phase difference from 18 to 30 years. Note that an increase in $t r_{L}$ leads to larger amplitudes and an increase in $c$ to lower amplitudes. The total effect on the ELA reconstruction constitutes the sum of both, and is therefore smaller than the individual effects. Figure $5.6 \mathrm{c}$ shows that the total effect on the amplitude of the ELA reconstruction is at maximum $10 \%$, when the melt rate at the glacier tongue is varied by $25 \%$.

Based on this sensitivity test, we conclude that the length response time and the climate sensitivity are most sensitive to uncertainties in the width of the glacier tongue, the melt rate at the glacier snout and the massbalance gradient at the equilibrium line altitude. The effect of these 
uncertainties on the final ELA reconstruction is, at most, $10 \%$ in the amplitude, and a phase difference of 6 .
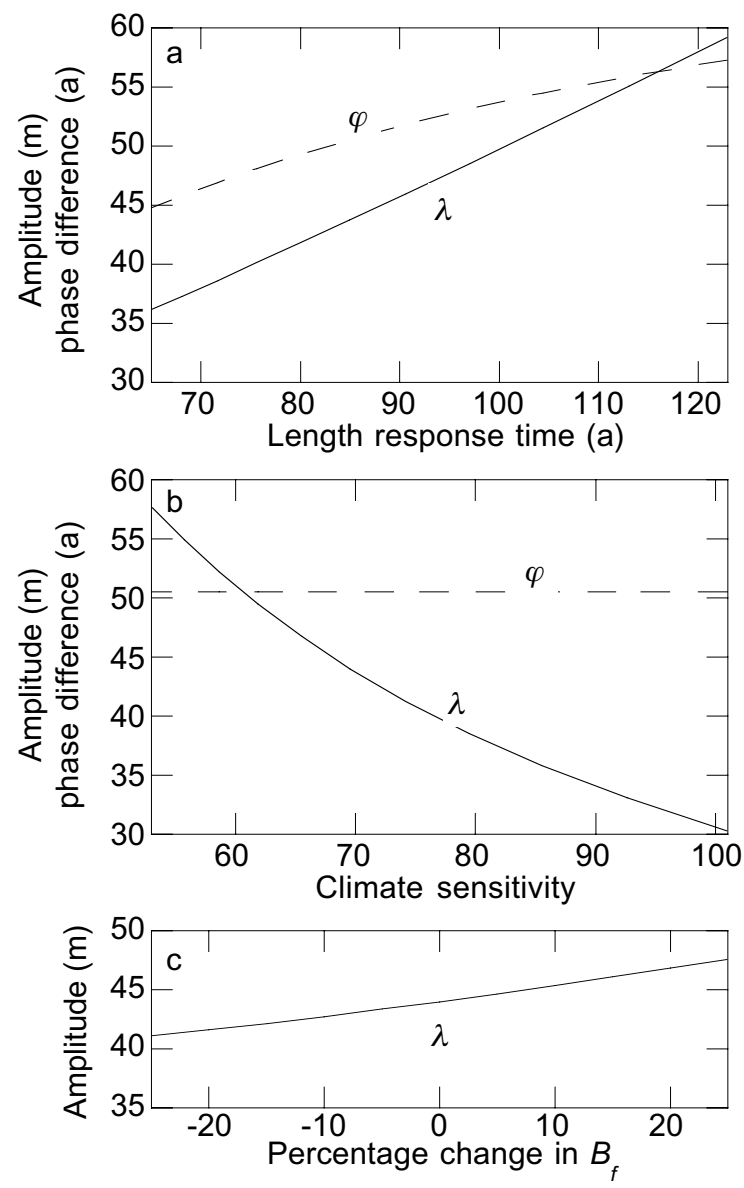

Figure 5.6: Amplitude (solid) and phase (dashed) of the ELA reconstruction of the fictitious glacier, when $t r_{L}$ is varied and c kept at $70(a)$, when $c$ is varied and $t_{L}$ is kept constant at $85 a(b)$, and when $B_{f}$ is varied by $25 \%$ (c).

Of course, this test provides no evidence that an uncertainty in the input parameters always leads to small changes in the ELA reconstructions because other glaciers may have different input parameters and length records than our fictitious glacier. Therefore, we also carried out a sensitivity test for Nigardsbreen, a glacier for which we have a long length record. We investigated the effect on the ELA reconstruction when the most sensitive parameters $\left(B_{f}, w_{f}\right.$ and $\left.\beta_{E}\right)$ were changed within their uncertainty ranges (Figure 5.7). This test indicates that the uncertainty in the width of the glacier tongue has the largest impact on the ELA reconstruction of Nigardsbreen, leading to a standard deviation of $4 \mathrm{~m}$ in $E^{\prime}(t)$, and a 
maximum deviation in the ELA of $9 \mathrm{~m}$ for the ELA maximum, which occurred in 1978.

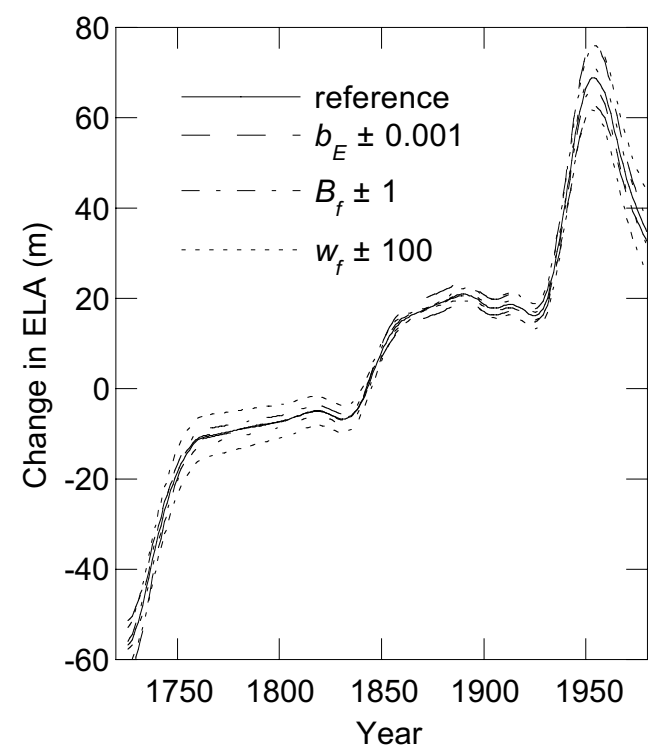

Figure 5.7: ELA reconstruction for Nigardsbreen for different values of the input parameters.

\subsection{CASE STUDY: EUROPEAN GLACIERS}

We tested the analytical model on length records of seventeen European glaciers (Figure 5.1). The length response times and climate sensitivities calculated from Equations (5.9) and (5.10) were compared to values derived from numerical flowline models (Section 5.4.1). The ELA reconstructions, which are presented in Section 5.4.2, were compared to reconstructions derived from numerical models and from temperature and precipitation records (Section 5.4.3).

\subsubsection{LENGTH RESPONSE TIME AND CLIMATE-SENSITIVITY RESULTS}

Table 5.2 shows the length response times and the climate sensitivities for the seventeen European glaciers calculated with the analytical model. For some glaciers the climate sensitivity, the length response time and the volume response time calculated with numerical models are given. The analytical length response times were expected to be shorter than the numerical length response times because the analytical length response time is in fact a volume response time (see Section 5.2.2). However, the results indicate that the analytical length response times correspond better 
to the numerical length response times than to the numerical volume response times. Hintereisferner is an exception because the numerical length response time of Hintereisferner (94a) is much longer than the analytical length response time (62 a).

The differences between the numerical and analytical values can be associated with topographical effects. For instance, the climate sensitivity increases if the glacier tongue reaches a point where the valley is narrow or the bed slope small. A numerical model takes into account these topographical features, whereas the analytical method assumes a constant bed slope and a constant width of the glacier tongue.

Table 5.2: Climate sensitivities and length response times calculated by the analytical method (ana) and by numerical models (num) and volume response times calculated by numerical models for several European glaciers; the numerical values are taken from literature referenced in this chapter.

\begin{tabular}{llllll}
\hline Glacier & $\begin{array}{l}\text { Climate } \\
\text { sensitivity }\end{array}$ & \multicolumn{2}{l}{$\begin{array}{l}\text { Length response } \\
\text { time (a) }\end{array}$} & $\begin{array}{l}\text { Volume } \\
\text { response } \\
\text { time (num) } \\
(a)\end{array}$ \\
\hline ana & num & ana & num & (a) \\
\hline Glacier d'Argentière & 25 & 35 & 33 & $27-45$ & \\
Mer de Glace & 57 & & 56 & & \\
Bas Glacier d'Arolla & 16 & & 48 & & \\
Rhonegletscher & 31 & 32 & 53 & 58 & 36 \\
Griesgletscher & 17 & & 61 & & \\
U. Grindelwaldgletscher & 64 & 49 & 52 & $34-45$ & \\
Vadret da Roseg & 29 & & 52 & & \\
Gurglerferner & 30 & & 41 & & \\
Oedenwinkelkees & 9 & & 37 & & \\
Langtalerferner & 27 & & 59 & & \\
Pasterzenkees & 32 & 32 & 62 & $70-137$ & $34-50$ \\
Hintereisferner & 25 & 31 & 62 & $79-109$ & $56-78$ \\
Forni & 62 & & 76 & & \\
Engabreen & 39 & & 53 & & \\
Nigardsbreen & 84 & 63 & 64 & $63-73$ & $38-47$ \\
Sólheimajökull & 53 & 26 & 87 & $65-73$ & $58-72$ \\
Svinafellsjökull & 20 & & 60 & & \\
\hline & & & & &
\end{tabular}

\subsubsection{RECONSTRUCTIONS OF THE EQUILIBRIUM LINE ALTITUDE}

The reconstructed equilibrium line altitudes of the seventeen European glaciers are shown in Figure 5.8. The ELAs of most glaciers show a similar pattern: after 1850 the ELAs increase, indicating a warmer period or less snowfall. At the beginning of the twentieth century, there is a small 
decrease in most ELAs. After that, the ELAs increase until around 1950 and then decrease slightly. The ELA reconstructions of Unterer

Grindelwaldgletscher and Glacier d'Argentière are amongst the longest records and show very similar fluctuations. However, the amplitudes of the fluctuations differ.

The ELA reconstruction of Rhonegletscher shows a large increase between 1850 and 1870 compared to the other reconstructions. This strong increase is probably an artefact of the analytical model, which uses a constant climate sensitivity and a constant length response time. Between 1850 and 1870, the terminus of Rhonegletscher rested on a small sloping surface, much smaller than the mean slope, implying that the glacier length was actually very sensitive to a change in the ELA. If a larger climate sensitivity was applied to Rhonegletscher, a smaller increase in the ELA

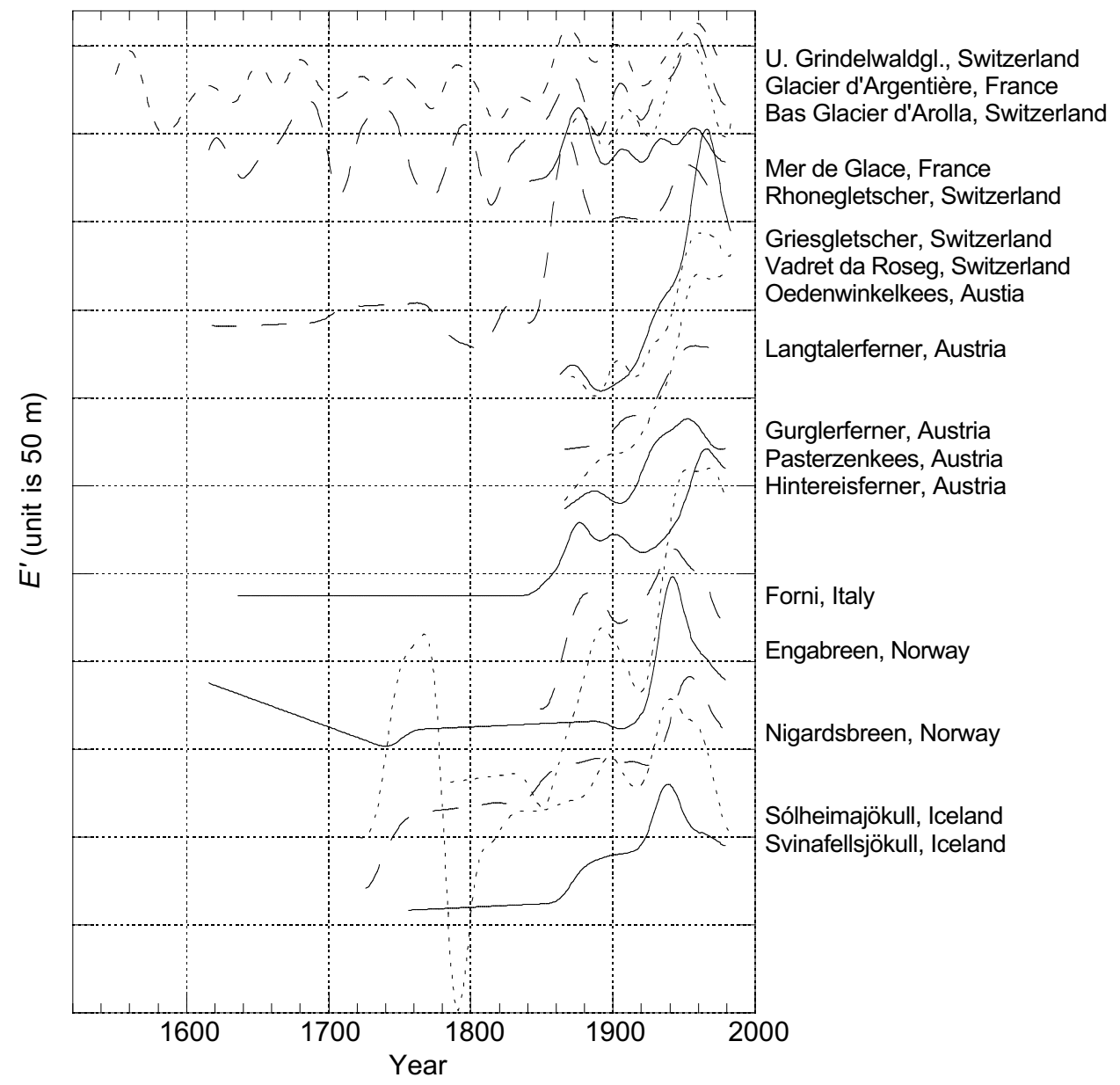

Figure 5.8: Reconstructed ELA records of seventeen European glaciers calculated with the analytical model. 
would have been calculated.

Hintereisferner reveals two very steep increases in the ELA after 1850, interrupted by significantly lower ELAs at the beginning of the twentieth century. The total increase in the ELA of Hintereisferner is rather large compared to other ELA reconstructions of glaciers in the Alps. The analytical model is probably less valid for Hintereisferner because the relative decrease in length over the total period of Hintereisferner is large: $30 \%$. The other glaciers in the Alps retreated on average $18 \%$.

Sólheimajökull's high ELAs around 1760 and low ELAs just before 1800 are necessary to explain its enormous retreat before and growth after 1780. Svinafellsjökull, however, does not show low ELAs before 1800. Still, the large ELA fluctuations of Sólheimajökull fit with documented changes in the Icelandic climate and sea ice extent (Ogilvie, 1992): during the 1780s, sea ice remained unusually close to Iceland. Besides, the large ELA fluctuations are confirmed by ELA reconstructions of Mackintosh and Dugmore (2000) that were calculated for Sólheimajökull with a numerical flowline model.

The ELA reconstructions of glaciers located in the same area exhibit resemblances. Therefore, means of the ELA reconstructions of the Icelandic and the Scandinavian glaciers and the glaciers of the western and eastern Alps were calculated (Figure 5.9). The eastern part of the Alps was separated from the western part by the $9^{\circ} \mathrm{E}$ meridian. Means were calculated over the period 1872-1974 because ELA reconstructions of all glaciers were performed for this period. The mean ELAs show an increase

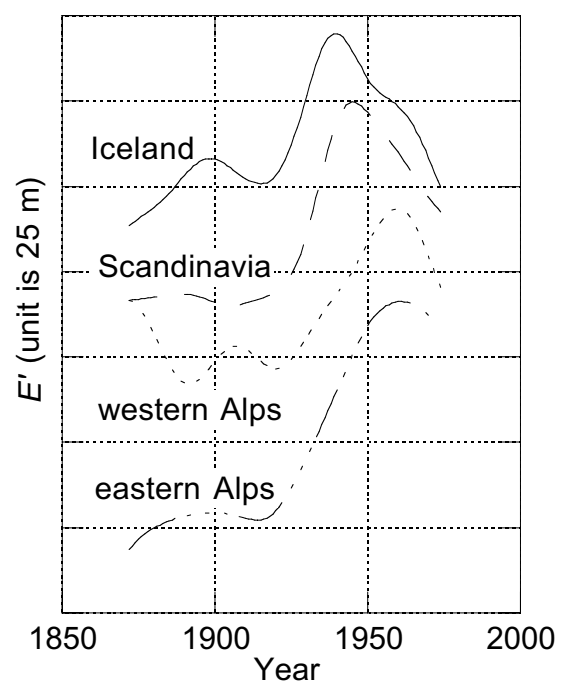

Figure 5.9: Means of the reconstructed ELA records of Scandinavia, Iceland, the eastern and the western Alps. 
after 1915. This is $45 \mathrm{~m}$ for the Icelandic glaciers, $59 \mathrm{~m}$ for the Scandinavian glaciers, $47 \mathrm{~m}$ for the western Alps and $64 \mathrm{~m}$ for the eastern Alps.

Apparently, air temperatures and snowfall have changed more in the eastern Alps than in the western Alps. The ELAs in northern Europe reached a maximum before 1950 and then decreased, unlike the ELAs of the Alps, which were at maximum after 1950 and show a smaller decrease after that. Furthermore, it is striking that the ELAs in the western Alps were also at a minimum before 1900, unlike the other ELA reconstructions.

\subsubsection{COMPARISON OF THE RESULTS WITH OTHER RECORDS}

It would be ideal to compare the ELA reconstructions with long records of ELA or mass-balance observations. However, these long observation records do not exist. Therefore, the results of the analytical model were compared with different types of data: results from a simple method and from a numerical model and from historical temperature and precipitation records.

Haeberli and Hoelzle (1995) calculated the average change in the mass balance over 1850-1970 from 13 length records of glaciers in the Alps. They assumed that the glaciers were stationary at the beginning and at the end of this period, and between 1890 and 1925. Subsequently, they supposed that a full dynamic response to a step change in the mass balance would explain the glaciers' retreat over these period. They then calculated an average mass loss of $-0.33 \pm 0.09 \mathrm{~m}$ w.e. $\mathrm{a}^{-1}$ during $1850-1970$. Mass-balance changes over the same period were also calculated for the glaciers in the Alps with the analytical model. The average of the mass-balance changes resulted in -0.21 $\pm 0.16 \mathrm{~m}$ w.e $\mathrm{a}^{-1}$, which is smaller compared to the step change in mass balance calculated by Haeberli and Hoelzle. The difference between the results of the two methods could be explained by the different approaches. First, the analytical model takes into account the response time and does not assume steady state situations before 1850 and after 1970. Second, Haeberli and Hoelzle use Equation (5.11) to determine the climate sensitivity of a glacier, which underestimates the climate sensitivity.

Figure 5.10 shows how the analytical ELA reconstruction of Nigardsbreen compares to the ELA reconstruction calculated from a numerical model (Oerlemans, 1997). The variation in the ELA reconstructions is of the same size, but there is a phase difference between the two reconstructions. Although the time at which the ELAs start to decrease or increase is similar, the locations of the maxima and minima differ. Firstly, this difference could be due to the numerical model, which uses a succession of step functions. Nine step functions were used to obtain the numerical ELA reconstruction as shown in Figure 5.10. Increasing the number of step functions will certainly influence the ELA reconstruction and probably lead to a reconstruction that is closer to the analytical 


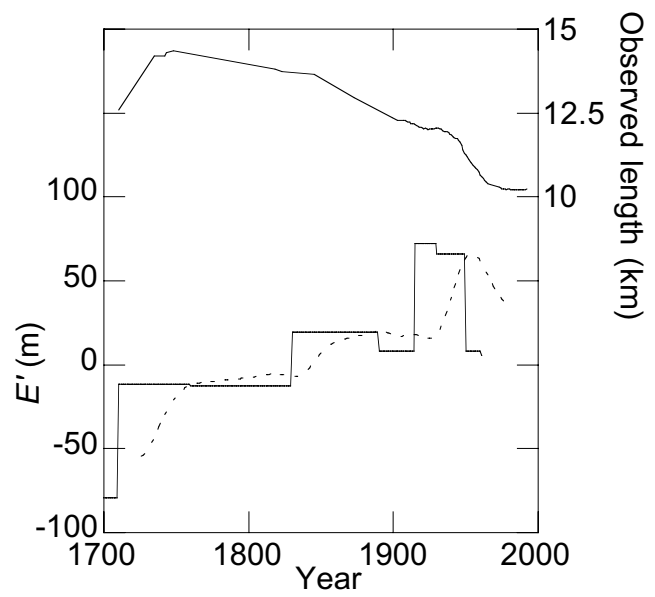

Figure 5.10: ELA reconstruction of Nigardsbreen calculated with the analytical model (dashed) and computed with a numerical model (solid) (Oerlemans, 1997)

(thin line); and the observed length record.

reconstruction. Secondly, the analytical model is based on the assumption that the glacier length directly responds to a change in the ELA. However, from numerical studies it is clear that glacier volume does indeed respond immediately to a change in the ELA, but glacier length starts reacting somewhat later. Therefore, in the analytical model, a change in the ELA is closer followed by a length change. In the numerical model, it takes more time for the glacier length to respond to a change in the ELA. The analytical ELA reconstruction is accordingly shifted forward in time compared to the numerical reconstruction. Thirdly, numerical models may respond too slowly to a mass-balance change due to the grid point spacing, which was $100 \mathrm{~m}$ for Nigardsbreen.

Comparing a mass-balance reconstruction with climate records is difficult because changes in the mass balance can be due to fluctuations in temperature, precipitation, sunshine duration or solar radiation. A method to derive a mass-balance history from historical meteorological data is using seasonal sensitivity characteristics (Oerlemans and Reichert, 2000). A seasonal sensitivity characteristic is the dependence of the mass balance on monthly anomalies in temperature and precipitation. Figure 5.11 shows the seasonal sensitivity characteristics of Griesgletscher and Rhonegletscher calculated by Oerlemans and Reichert (2000) from a mass-balance model of Oerlemans (1992). The figure illustrates that the mass balance of Rhonegletscher is more sensitive to changes in precipitation than the mass balance of Griesgletscher. Furthermore, a temperature increase in winter does not change the mass balance of Griesgletscher and hardly influences the mass balance of Rhonegletscher. 

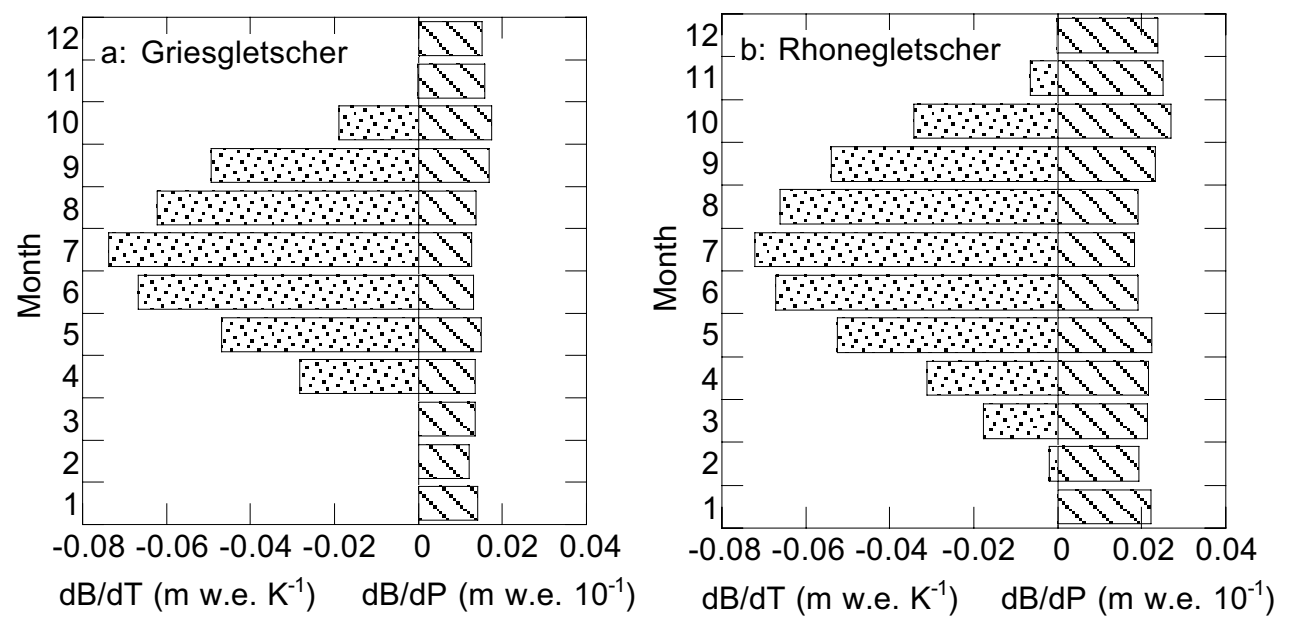

Figure 5.11: Seasonal sensitivity characteristics of Griesgletscher (a) and

Rhonegletscher (b) calculated from a mass-balance model (Oerlemans and Reichert, 2000).

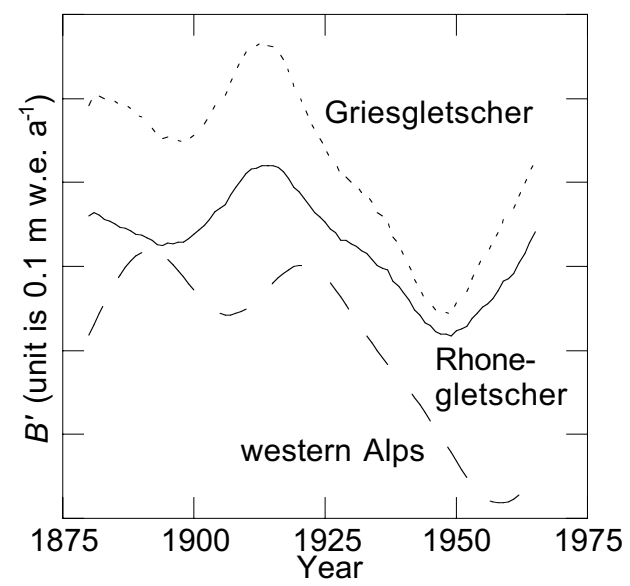

Figure 5.12: Mean mass-balance reconstruction of glaciers in the western Alps (dashed) and mass-balance reconstructions calculated with seasonal sensitivity characteristics of Griesgletscher (dotted) and Rhonegletscher (solid). A Gaussian filter is applied to the mass-balance reconstructions.

Mass-balance reconstructions of these two glaciers in the Alps were calculated from the seasonal sensitivity characteristics and compared with the reconstructions calculated with the analytical model. Therefore, long records of monthly precipitation and temperature anomalies were needed. The monthly precipitation of Beatenberg (Switzerland) and the monthly homogenised high-elevation (above $1500 \mathrm{~m}$ a.s.l.) temperature record of $46^{\circ}$ 
$\mathrm{N}, 8^{\circ} \mathrm{E}$ taken from Böhm et al. (2001) were used for both glaciers. The massbalance reconstructions calculated from the seasonal sensitivity characteristics were then filtered with a Gaussian filter.

The mass-balance reconstructions of Griesgletscher and Rhonegletscher and the mean mass-balance history of the glaciers of the western part of the Alps calculated with the analytical model are shown in Figure 5.12. The mass-balance reconstructions show similar fluctuations with amplitudes of similar magnitude. However, there is again a phase difference between the reconstructions. The analytical mass-balance reconstruction is shifted about 10 years forward in time, which is less than the phase difference between the analytical and the numerical model results.

\subsubsection{CONCLUSIONS OF THE CASE-STUDY}

Application of the analytical model to seventeen European glaciers shows that the model is useful to derive a climate signal from a glacier length record. The calculated mass-balance fluctuations are in agreement with mass-balance reconstructions derived from numerical models and from temperature and precipitation records using seasonal sensitivity characteristics. The length response times and climate sensitivities calculated with the analytical model are in agreement with values calculated from numerical models.

However, the ELA reconstructions calculated with the analytical model are shifted forward in time by a decade compared to the numerical mass-balance reconstruction and the mass-balance reconstructions calculated from temperature and precipitations records. This is due to the model assumption that glacier length immediately responds to a change in the mass balance. Another limitation of the model is that topography is represented in a schematic way. The topography is especially important when the slope of the bedrock and the valley width change along the glacier. Then, the climate sensitivity and the length response time depend considerably on the position of the terminus, which in turn will influence the mass-balance reconstruction. Therefore, the analytical model is not suitable for glaciers with strong variations in the slope and width of the glacier valley.

\subsection{GLOBAL GLACIERS AND THEIR LENGTH RECORDS}

Building a data set of useful length records of worldwide glaciers was difficult because most non-European glaciers have only been measured since the beginning of the twentieth century. We aimed to find records that go back to before 1900. A second demand of our data set was that the length 
fluctuations needed to be small $(<\sim 20 \%)$ compared to the total glacier length, to justify the assumption of a quasi-linear response. Thirdly, the glacier type was bound to be valley or outlet. Lastly, we needed information about the geometry and the mass balance to calculate the response time and the climate sensitivity. This led to a collection of fourteen glaciers from countries other than European, to which we added five European records to obtain a global picture (Figure 5.13).

The glaciers of our data set are located in six regions: Canada, U.S.A., South America, Europe, Asia and New Zealand. All of them have retreated over the previous century, but $60 \%$ of them also slightly advanced

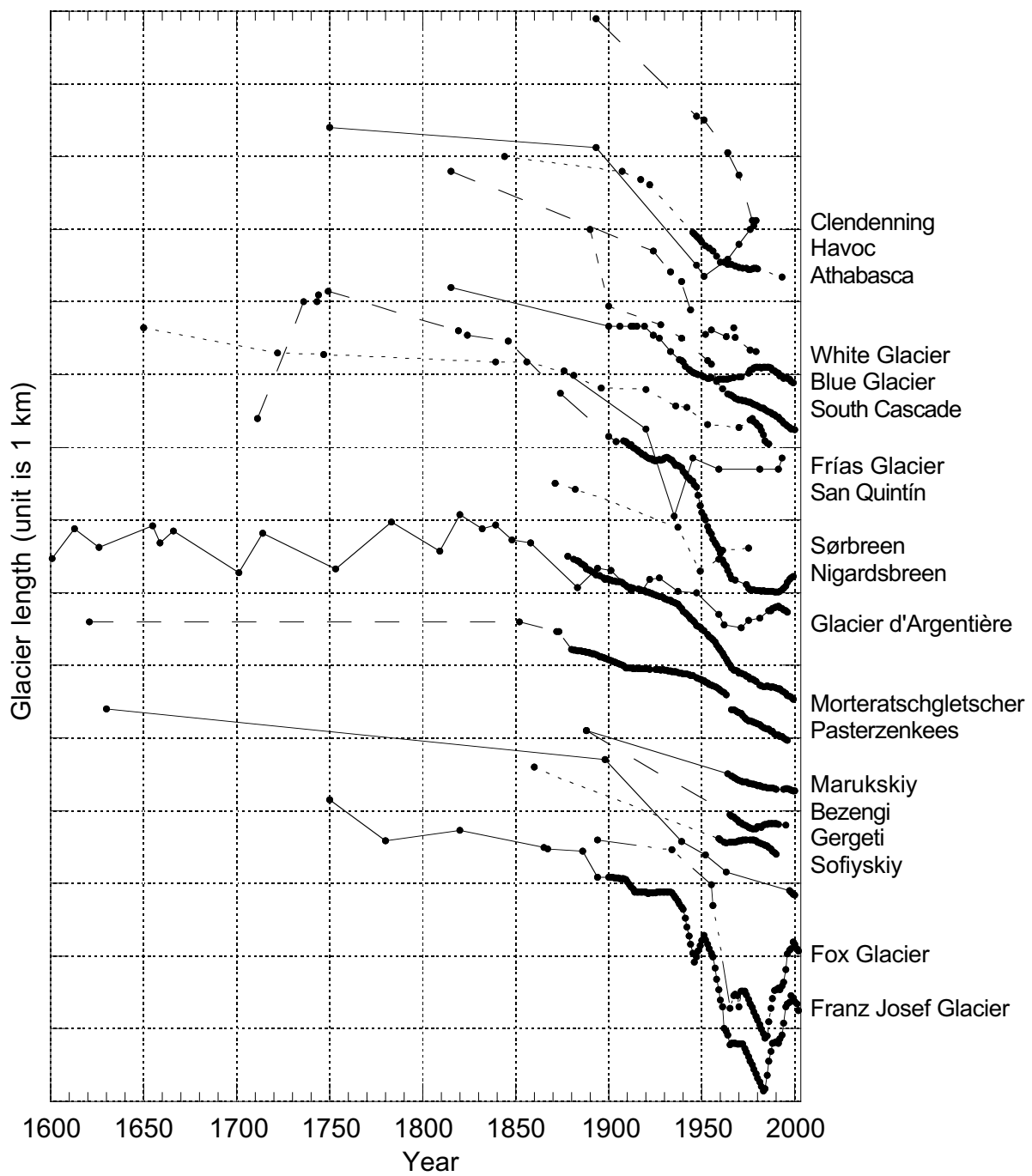

Figure 5.13: Glacier length fluctuations of the nineteen glaciers of our data set. 
Table 5.3: Model parameters of the nineteen glaciers, the calculated length response time $\left(t_{r L}\right)$, climate sensitivity $(c)$, and the mean annual precipitation ( $\mathrm{Zuo}$ and Oerlemans, 1997b). The first five letters of their names abbreviate the glacier names. ( $L_{0}$ : reference glacier length, $A_{0}$ : reference glacier area, s: mean surface slope, $s_{f}:$ surface slope of the glacier snout, $w_{f}$ : width of glacier tongue, $B_{f}$ melt rate at the glacier terminus, $\beta_{E}$ : mass-balance gradient at the ELA, $\beta$ : mass-balance gradient of the glacier)

\begin{tabular}{lllllllllllll}
\hline Glacier & $\begin{array}{l}L_{0} \\
(\mathrm{~km})\end{array}$ & $\begin{array}{l}A_{0} \\
(\mathrm{~km})\end{array}$ & $\begin{array}{l}s \\
(\%)\end{array}$ & $\begin{array}{l}s_{f}(\%) \\
(\%)\end{array}$ & $\begin{array}{l}w_{f} \\
(\mathrm{~m})\end{array}$ & $\begin{array}{l}B_{f} \\
(m w . e .\end{array}$ & $\beta$ & $\beta_{E}$ & $\begin{array}{l}\left.\left.t_{L}\right)^{-1}\right) \\
(a)\end{array}$ & $\begin{array}{l}c \\
P_{a n n} \\
\left(m a^{-1}\right)\end{array}$ \\
\hline Clend & 11.1 & 26.5 & 15 & 8 & 500 & -8 & 0.0052 & 0.0065 & 80 & 49 & 2.5 \\
Havoc & 7.0 & 9.5 & 19 & 30 & 250 & -6.9 & 0.0052 & 0.0065 & 46 & 36 & 2.5 \\
Athab & 9.3 & 15.0 & 17 & 8 & 550 & -4.7 & 0.0058 & 0.0064 & 102 & 43 & 0.75 \\
White & 3.3 & 3.8 & 27 & 35 & 290 & -5.6 & 0.010 & 0.010 & 18 & 16 & 4 \\
Blue & 4.3 & 5.5 & 27 & 160 & 400 & -5.7 & 0.010 & 0.010 & 8 & 10 & 4 \\
South & 3.1 & 2.9 & 16 & 10 & 400 & -6 & 0.0105 & 0.023 & 27 & 26 & 2.5 \\
Frías & 6 & 10.5 & 21 & 10 & 400 & -12 & 0.0110 & 0.017 & 33 & 38 & 3 \\
Sanqu & 60 & 765.0 & 3 & 5 & 8500 & -15.8 & 0.0150 & 0.015 & 76 & 128 & 2 \\
Sørbr & 9 & 15 & 20 & 8 & 800 & -4 & 0.005 & 0.006 & 105 & 32 & 0.7 \\
Nigar & 9.6 & 48.2 & 17 & 23 & 500 & -10 & 0.0079 & 0.0086 & 68 & 84 & 4 \\
Argen & 9.4 & 15.6 & 16 & 16 & 400 & -12.2 & 0.0078 & 0.0071 & 34 & 25 & 2 \\
Morte & 7.0 & 17.2 & 29 & 6 & 650 & -6.5 & 0.0046 & 0.0065 & 88 & 29 & 2 \\
Paste & 9.4 & 19.8 & 17 & 10 & 750 & -5.8 & 0.004 & 0.007 & 62 & 32 & 2 \\
Maruk & 4.0 & 3.1 & 17 & 10 & 500 & -2.5 & 0.0100 & 0.0061 & 91 & 19 & 1.5 \\
Bezen & 17.6 & 31.1 & 17 & 10 & 450 & -7.2 & 0.0014 & 0.0042 & 85 & 42 & 1.5 \\
Gerge & 8.5 & 7.1 & 30 & 20 & 200 & -3.9 & 0.0014 & 0.0042 & 78 & 37 & 1.5 \\
Sofiy & 7.0 & 20 & 20 & 10 & 500 & -5 & 0.0054 & 0.0073 & 97 & 63 & 0.375 \\
Fox & 13.2 & 34.7 & 24 & 5 & 350 & -23 & 0.011 & 0.017 & 56 & 92 & 1.87 \\
Franz & 10.3 & 32.6 & 25 & 8 & 425 & -22 & 0.011 & 0.017 & 38 & 72 & 1.87 \\
\hline
\end{tabular}

after 1950 (Figure 5.13). Retreat rates, total retreat and periods of retreat vary widely between the glaciers. Table 5.3 gives information about the geometry and the mass-balance regime of the glaciers. These parameter values were used as model input. The length records and the input data were either collected or estimated from data of the World Glacier Monitoring Service (Haeberli et al., 1998), the World Glacier Inventory, from Dyurgerov (2002) or from other references mentioned in the text.

\subsubsection{CANADA}

The three Canadian glaciers of the data set are Athabasca (Rockies), Clendenning and Havoc (Coast Mountains). Athabasca is an outlet glacier 
of the Columbia Ice Field, an ice cap of roughly $325 \mathrm{~km}^{2}$. The glacier flows over three icefalls into an alpine valley (Reynolds and Young, 1997). It has retreated rapidly since 1910 until 1960, after which a slowdown in the retreat rate occurred. Clendenning and Havoc, two valley type glaciers, are located closer to the ocean and their glacier termini reach further down ( \pm $1000 \mathrm{~m}$ a.s.l.) than Athabasca ( $\pm 1950 \mathrm{~m}$ a.s.l.). The length records of Clendenning and Havoc do not show similar patterns, although both are located in the Clendenning valley. This could be attributed to differences in glacier geometry because the glacier tongue of Havoc is much steeper and narrower.

\subsubsection{U.S.A.}

White and Blue Glaciers are located in the Olympic Mountains, which is $\pm 55 \mathrm{~km}$ from the Pacific Ocean. The climate of the Olympic mountains is strongly maritime and involves the greatest precipitation of any area in the U.S.A., excluding Alaska and Hawaii (Armstrong, 1989). Blue Glacier has a steeper and narrower glacier tongue than White Glacier and has retreated less. South Cascade lies in the North Cascade Range, $250 \mathrm{~km}$ from the ocean. This glacier receives less snow $( \pm 3 \mathrm{~m}$ w.e.) than White and Blue Glaciers ( \pm 4 m w.e.) (Rasmussen and Conway, 2001). Mass-balance measurements have been carried out on Blue Glacier (Conway et al., 1999) and South Cascade (Krimmel, 2000). Armstrong (1989) showed that Blue Glacier had a slightly positive mass balance between 1956 and 1986 (0.3 m) and Krimmel (1989) found a mean negative balance for South Cascade $(-0.22$ m) for 1959 to 1985 . Blue Glacier has not retreated significantly since 1950, while the length record of South Cascade shows an ongoing retreat. Rasmussen and Conway (2001) concluded that South Cascade has been more out of balance than White Glacier, which they ascribed to differences in geometry between the two glaciers, rather than in climate.

\subsubsection{SOUTH AMERICA}

Frías Glacier (Argentina) is an outlet glacier situated on the east side of Mount Tronador. This ice cap is the northernmost ice body of Argentina. Measurements from a weather station in the Rio Frías Valley of Frías Glacier indicated that the annual precipitation amounts to $4300 \mathrm{~mm} \mathrm{a}^{-1}$ (Perez Moreau, 1945). The glacier fluctuations have been recorded since 1976 and Villalba et al. (1990) dated oscillations of Frías Glacier by using tree-ring analysis. Between 1850 and 1900, the retreat rate was $7 \mathrm{~m} \mathrm{a}^{-1}$ and increased to $10 \mathrm{~m} \mathrm{a}^{-1}$ between 1910 and 1940 .

San Quintín is further south than Frías Glacier and is the largest glacier of our data set. It is a piedmont outlet glacier of the North Patagonian Ice Field in Chile. San Quintín flows to the west, onto an 
outwash plain. It receives between 3700 and $6700 \mathrm{~mm}$ precipitation per year. Winchester and Harrison (1996) investigated the ice front retreats and advances and concluded that precipitation is the main factor controlling the fluctuations. The length record of San Quintín shows a peculiar glacier retreat just before 1935 from which it recovers after 1935, which does not show up in the other length records.

\subsubsection{EUROPE}

Sørbreen is a glacier on Jan Mayen, the northernmost island on the Mid-Atlantic Ridge $\left(71^{\circ} \mathrm{N}, 8^{\circ} \mathrm{W}\right)$. This glacier flows southwards to the ocean, from the 2277- $\mathrm{m}$ high Beerenberg volcano. The climate is cool oceanic with an annual mean air temperature of $-1.2{ }^{\circ} \mathrm{C}$ at sea level. The island is surrounded with pack ice during winter and spring (Anda et al., 1985). Nigardsbreen is an outlet glacier in Norway, flowing from the largest ice cap of continental Europe (Jostedalsbreen) in a southeasterly direction. It is a maritime glacier, located close to the Atlantic ocean. It advanced very rapidly between 1710 and 1748 and after 1988, it slightly advanced again. Pohjola and Rogers (1997) claimed that this advance is due to enhanced westerly maritime flow after 1980 leading to high winter accumulation and low summer ablation.

Glacier d'Argentière (France), Morteratschgletscher (Switzerland) and Pasterzenkees (Austria) are valley glaciers in the European Alps, where the climate is more continental. Glacier d'Argentière has been documented well, regarding the numerous fluctuations registered before 1850. Its length record is the longest of our data set and has been studied by Huybrechts et al. (1989). Glacier d'Argentière advanced after 1970, in contrast to Morteratschgletscher and Pasterzenkees. Pasterzenkees is the longest glacier of the Austrian Alps. It retreated roughly during two periods: between 1870 and 1910 and after 1930 (Zuo and Oerlemans, 1997a).

\subsubsection{ASIA}

Marukskiy, Bezengi and Gergeti are valley glaciers in the Caucasus Mountains. Their length records contain only a few measurements, which explains the straight lines in Figure 5.13. The mass-balance gradient of these glaciers is relatively small and the melt rate at the glacier tongue is low (Table 5.3). The maximum elevation of Bezengi and Gergeti is over $5000 \mathrm{~m}$ a.s.l. Sofiyskiy glacier is located in the Altai Mountains of central Asia, a border region between Russia and Mongolia. It is a so-called continental, summer-accumulation type glacier. Sofiyskiy glacier is a valley type glacier consisting of three basins. The most rapid retreat of Sofiyskiy glacier occurred between 1900 and 1940 (Pattyn et al., 2003; De Smedt and Pattyn, 2003). 


\subsubsection{NeW ZeALAND}

Fox and Franz Josef are valley glaciers in the maritime climate of the Southern Alps of New Zealand. They receive between 5 and $15 \mathrm{~m}$ precipitation per year. Their glacier tongues lie at very low elevations, 425 and $305 \mathrm{~m}$ a.s.l. for Franz Josef and Fox Glaciers respectively (Hooker and Fitzharris, 1999). The length records show similar patterns: a rapid retreat after 1940 and a major advance after 1982. This advance phase is characterised by higher precipitation and is also related to a higher frequency of El Niño events (Hooker and Fitzharris, 1999).

\subsection{RESULTS FOR WORLDWIDE GLACIERS}

\subsubsection{LENGTH RESPONSE TIMES AND CLIMATE SENSITIVITIES}

We calculated the length response time and climate sensitivity with Equations (5.9.) and (5.10) for all nineteen glaciers and plotted the values in Figure 5.14 (see also Table 5.3 for the precise values of $t r_{L}$ and $c$ ). Maritime glaciers often have high climate sensitivities (San Quintín, Fox, Nigardsbreen and Franz Josef), since they have large mass-balance gradients. However, the glaciers of the U.S.A. (South Cascade, White and Blue), which are also located in maritime areas, have low climate sensitivities. This is due to their small surface areas and relative wide glacier tongues. Athabasca Glacier has the longest length response time, which is partly caused by its low melt rate at the glacier terminus. Blue

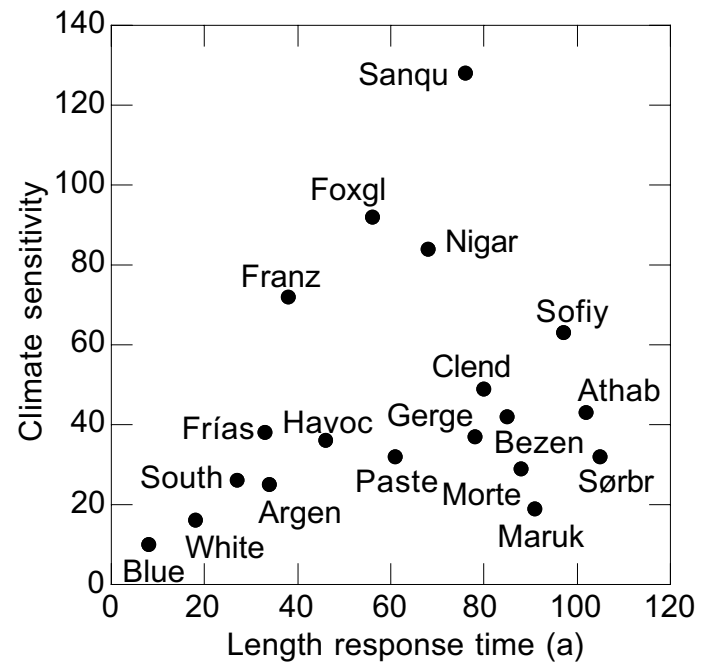

Figure 5.14: Climate sensitivity and length response time for all glaciers. The first five letters of their names abbreviate the names of the glaciers. 
Glacier has the shortest length response time and the lowest climate sensitivity. Since this glacier is situated on a steep slope, the contribution of the mass balance - surface height feedback to $t r_{L}$ and $c$ is small.

\subsubsection{ELA RECONSTRUCTIONS}

Figure 5.15 shows the reconstructed ELAs. Athabasca and Havoc show similar fluctuations in the ELA although the ELA of Havoc started to increase some years before 1900 and that of Athabasca some years after 1900. The ELA reconstruction of Clendenning shows neither any resemblances with the other Canadian ELAs nor with the reconstructions for the U.S.A. because the ELA does not stabilise around 1950. The reconstructed ELAs of White and Blue Glaciers are similar, but the fluctuation in White Glacier's ELA is larger.

The ELAs of Frías and San Quintín show hardly any correspondence. The ELA of San Quintín decreases exceptionally after 1920. As San Quintín is a piedmont glacier and not a valley glacier, it could be argued whether its ELA reconstruction is reliable. However, the rapid decrease could be explained by an increase in precipitation between 1919 and 1935 (Winchester and Harrison, 1996). Winchester and Harrison (1996) also found that precipitation is a more dominant factor than air temperature in controlling the fluctuations of San Quintín.

The ELA of the European glaciers increased between 1920 and 1950. Sørbreen reached a maximum ELA before 1950 and the other glaciers after 1950. Morteratschgletscher's increase in the ELA is large compared to the other ELA reconstructions in the European Alps. Bogen et al. (1989) found that the increase in the ELA of Nigardsbreen that occurred between 1925 and 1955 is related to a series of excessive warm summers.

Marukskij, Bezengi and Gergeti all show slowly increasing ELAs until 1950-1970 and a decrease afterwards. The ELA of Sofiyskiy increases rapidly around 1900 and starts decreasing already after 1930.

The reconstructed ELAs of Fox and Franz Josef show very similar patterns, with a rapid increase in the ELA after 1920 until 1960. The high ELAs around 1960 are strongly linked with changes in the circulation patterns over the southwest Pacific region (Fitzharris et al., 1992). At that time, summer pressures over New Zealand were higher than normal due to a pole-ward shift of the subtropical high, favoring clearer skies and more ablation. Moreover, snow accumulation was unusually low in the 1960 s and 1970s.

\subsubsection{WORLDWIDE PATTERN IN ELA FLUCTUATIONS}

For all glaciers, ELA reconstructions were calculated for the period between 1910 and 1959. We therefore estimated an average worldwide 

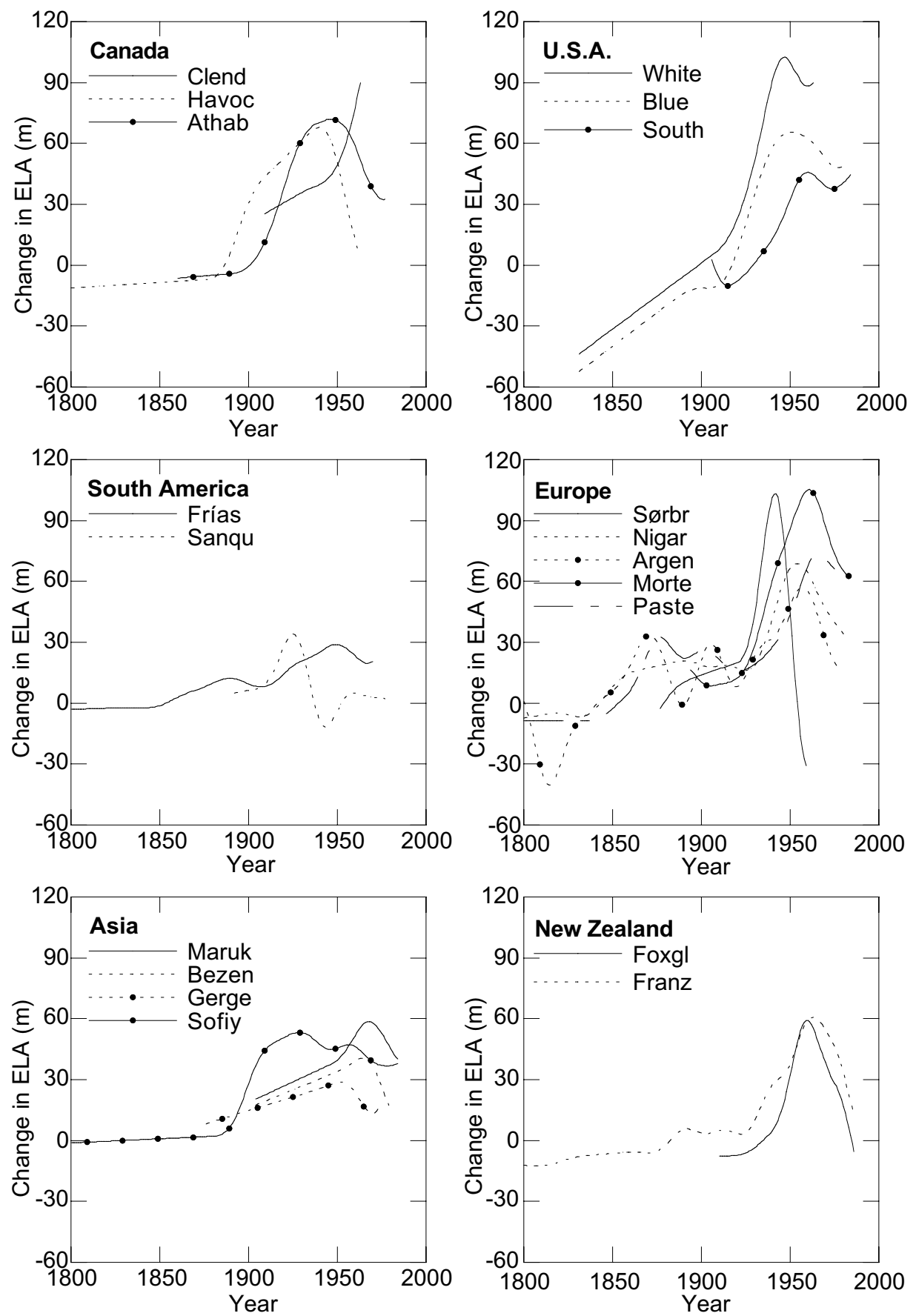

Figure 5.15: ELA reconstructions for all glaciers plotted separately for six regions.

The first five letters of their names abbreviate the names of the glaciers. 
change in the ELA for this period (Figure 5.16a). The average ELA increased by $33 \mathrm{~m}$ between 1910 and 1959, with a standard error of $8 \mathrm{~m}$. According to Figure 5.15, this increase was most pronounced in the U.S.A. and New Zealand and less in Asia. Generally, the reconstructed ELAs increased strongly during the first fifty years of the twentieth century. Except for San Quintín, they all decreased again in the second half of the twentieth century until 1980, when most of our ELA reconstructions end. This implies that the first half of the twentieth century was warmer or drier than the period before 1900. After 1960, the climate returned to a situation that favours lower ELAs.
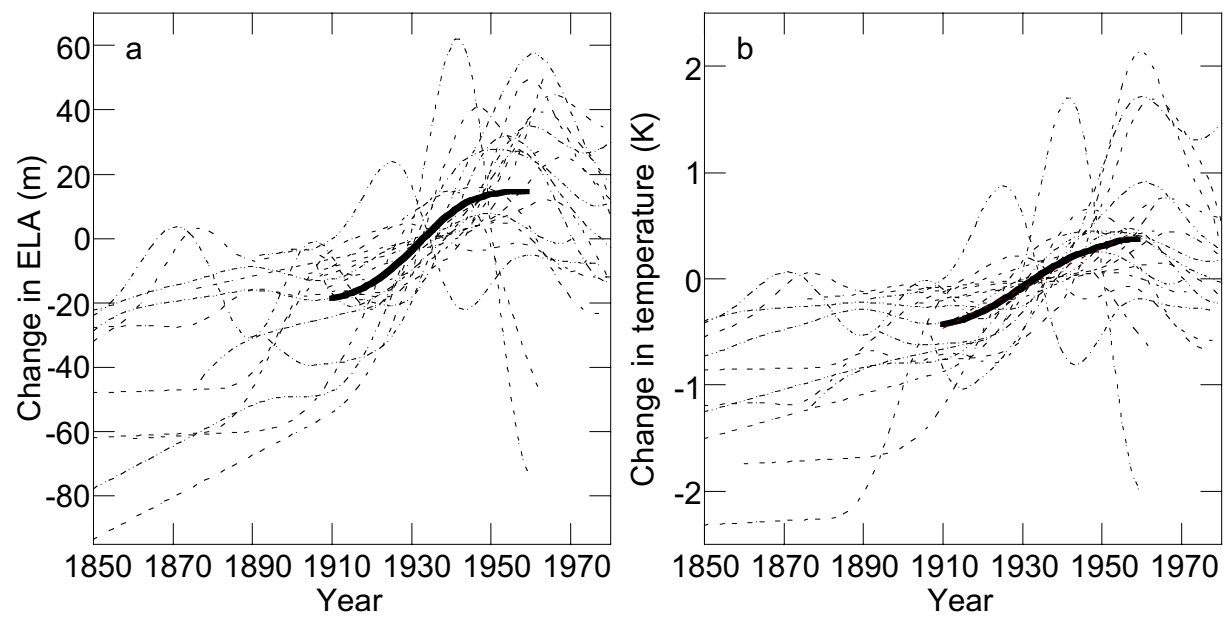

Figure 5.16: (a) All ELA reconstructions (dashed) and the average ELA reconstruction (solid). The ELA reconstruction of each glacier is shifted compared to Figure 5.15 in order to obtain a mean $E^{\prime}(t)$ of zero over the period 1910 to 1959. (b) Same as Figure 5.16a, but for temperature reconstructions.

\subsubsection{RECONSTRUCTIONS OF TEMPERATURE}

If we assume that the changes in the ELA were solely due to temperature variations, we can derive historic trends in air temperature from the ELA reconstructions. We then only need to know the sensitivity of the glacier mass balance to the temperature. A change in the ELA $\left(E^{\prime}(t)\right)$ can be easily translated into a mass-balance change $\left(B^{\prime}(t)\right)$ by multiplying it with the mass-balance gradient. We estimated for each glacier the sensitivity of the mass balance to a change in temperature $\left(T^{\prime}(t)\right)$ by using a parameterisation of Oerlemans (2001):

$$
\frac{B^{\prime}(t)}{T^{\prime}(t)}=-0.271\left(P_{a n n}\right)^{0.597}
$$


Oerlemans (2001) based this parameterisation on calculations with a massbalance model applied to a set of thirteen glaciers. The sensitivity is a function of mean annual precipitation $\left(P_{a n n}\right)$ and increases for wetter climates. We chose, for each glacier, a value for the annual precipitation, based on the compiled data of Zuo and Oerlemans (1997b) (Table 5.3). Figure $8 b$ shows the calculated temperature reconstructions for each glacier and an average temperature trend. Between 1910 and 1959, the average increase in air temperature was $0.8 \mathrm{~K}$ and the standard error in the mean $0.2 \mathrm{~K}$. The calculated linear trend in temperature was $0.19 \mathrm{~K}$ per decade.

\subsection{DiscUSSION}

Our results agree with those of the IPCC (2001) on an increase in the global surface air temperature between 1910 and 1945 if we assume that the ELA fluctuations were solely explained by changes in temperature. In addition, cooling during the period 1946 to 1975 in the Northern Hemisphere (IPCC, 2001) is consistent with the observed lowering in our reconstructed ELAs. However, the warming rate reported by the IPCC for the period 1910-1945 is less ( $0.14 \mathrm{~K}$ per decade) than estimated from the ELA reconstructions for 1910 to 1959 ( $0.19 \mathrm{~K}$ per decade). This may be associated with the fact that we excluded precipitation and cloudiness as possible causes of the ELA fluctuations. Besides, we estimated this global temperature increase from only a few glacier records that are also not evenly distributed over the globe.

The IPCC also concluded that the Southern Hemisphere has been warming more uniformly during the twentieth century compared with the Northern Hemisphere and shows warming between 1946 and 1975 too. This is in contrast with the decreasing ELAs of the glaciers in New Zealand, unless precipitation has increased simultaneously. Regional differences from the hemispherical mean could also account for this discrepancy.

Our results do not give rise to the conclusion that there was a second period (1976 to 2000) of global warming, as claimed by the IPCC (2001). This is because most of our reconstructed ELAs do not extend beyond 1980, due to the time span of the length records and the Gaussian filter that we applied.

As we related changes in the ELA to changes in the specific mass balance, we could as well determine the mean specific mass balance for each glacier between 1910 and 1959. Averaged over all glaciers, this results in a mean specific mass balance of $-0.18 \mathrm{~m}$ w.e. $\mathrm{a}^{-1}$ with a standard error of $0.04 \mathrm{~m}$ w.e. $\mathrm{a}^{-1}$. If we assume this value to be representative for all glaciers in the world, the mean rise in sea level due to the retreating glaciers can be roughly estimated. Assuming an area of $527900 \mathrm{~km}^{2}$ for all of the world's 
small ice caps and glaciers excluding Greenland and Antarctica (Zuo and Oerlemans, 1997b), the estimated total rise in sea level is $1.3 \mathrm{~cm}$ over the period 1910-1959 and the mean rate is $0.3 \mathrm{~mm} \mathrm{a}^{-1}$. This rate is in accordance with the estimated contribution of glaciers to sea level rise for the period 1910-1990 reported by the IPCC (2001). However, we should realise that this estimate is not very accurate, as we did not include any information from glaciers in Alaska and north-east Canada, which are highly glacierised areas. Neither did we use a weighted average to account for the size of each glacierised region.

\subsection{SUMMARY}

The purpose of this study was to extract information on the past climate from glacier length fluctuations by means of deriving historical ELAs or mass-balance recnstructions. The model that we developed for extracting ELAs from glacier length fluctuations is a simple analytical one, based on the assumption that the change in length can be described by a linear response equation. Its advantage is that it takes the response time and the geometry of the glacier as well as the mass balance - surface height feedback into account. Furthermore, it requires less information about a glacier than is needed for a numerical model.

We carried out a sensitivity test for a fictitious glacier and found that the uncertainty in the width of the glacier tongue, the melt rate at the glacier terminus and the mass-balance gradient have the largest impact on the ELA reconstruction. More specifically, for Nigardsbreen, the standard deviation in the ELA reconstruction due to uncertainties in the input parameters was estimated to be $4 \mathrm{~m}$.

We performed a case-study, in which we tested the analytical model on length records of seventeen European glaciers. The results indicate that the model is useful to derive a climate signal from a glacier length record. The calculated mass-balance fluctuations are in agreement with massbalance reconstructions derived from numerical models and from temperature and precipitation records using seasonal sensitivity characteristics. However, the ELA reconstructions calculated with the analytical model are shifted forward in time by a decade compared to the numerical mass-balance reconstruction and the mass-balance reconstructions calculated from temperature and precipitations records. The analytical model is not suitable for glaciers with strong variations in the slope and width of the glacier valley and only valid for relatively small glacier length fluctuations.

We then extracted information on the past climate from glacier length fluctuations for nineteen glaciers from different parts of the world. The results show that all glaciers of our data set experienced an increase in the 
ELA between 1900 and 1960. The average increase between 1910 and 1959 is $33 \mathrm{~m}$. After around 1960 until 1980, the ELAs decreased to lower elevations. This implies that during the first half of the twentieth century, climate was warmer or drier than before. The results support the evidence that an average global temperature increase took place between 1910 and 1945 and a sea level increase of $0.3 \mathrm{~mm} \mathrm{a}^{-1}$ (IPCC, 2001). The ELA reconstructions also reveal regional differences. Changes in the ELA were most pronounced for North America, Europe and New Zealand. After 1960 up to 1980, the climate reverted to conditions supporting lower ELAs.

Acknowledgements - We would like to thank Martin Hoelzle and Regula Frauenfelder of the WGMS for providing the glacier length records, Reichert Böhm for the temperature records and Maurice Schmeits for the precipitation record. We are grateful to a number of people who supplied us with useful data and information on glaciers: Ricardo Villalba, Mike Demuth, Frank Pattyn, Bert De Smedt, Trevor Chinn, Andrey Glazovsky and $\mathrm{Al}$ Rasmussen. We thank the members of the Ice \& Climate group of the IMAU and and especially Wouter Greuell, Andrew Mackintosh, Aleth Bolt and Angelina Souren for their helpful comments.

\section{REFERENCES}

Anda, A., Orheim, O. and Mangerud, J. 1985. Late Holocene glacier variations at Jan Mayen. Polar Research, 3 n.s., 129-140.

Aniya, M. 1999. Recent glacier variations of the Hielos Patagónicos, South America, and their contribution to sea-level change. Arctic, Antarctic and Alpine Research, 31(2), 165-173.

Armstrong, R.L. 1989. Mass balance history of Blue Glacier, Washington, USA. In Oerlemans, J., editor, Glacier fluctuations and climatic change, Dordrecht: Kluwer Academic Publishers, 183-192.

Benn, D.I. and Lehmkuhl, F. 2000. Mass balance and equilibrium-line altitudes of glaciers in high-mountain environments. Quaternary International, 65/66, 15-29.

Bogen, J., Wold, B. and Østrem, G. 1989. Historic glacier variations in Scandinavia. In Oerlemans, J., editor, Glacier fluctuations and climatic change, Dordrecht: Kluwer Academic Publishers: 109-128.

Böhm, R., Auer, I., Brunetti, M., Maugeri, M., Nanni, T. and Schöner, W. 2001. Regional temperature variability in the European Alps 1760-1980 from homogenized instrumental time series. International Journal of Climatology, 21(14), 1779-1801.

Callendar, G.S. 1950. Note on the relation between the height of the firn line and dimensions of a glacier. Journal of Glaciology, 1(8), 459-461.

Chinn, T.J. 1996. New Zealand glacier responses to climate change of the past century. New Zealand Journal of Geology and Geophysics, 39, 415-428.

Conway, H., Rasmussen, L.A., Marshall, H.P. 1999. Annual mass balance of Blue glacier, U.S.A.: 1955-97. Geografiska Annaler, 81A(4), 509-520. 
De Smedt, B. and Pattyn, F. 2003. Numerical modelling of historical front variations and dynamic response of Sofiyskiy Glacier, Altai Mountains, Russia. Annals of Glaciology, 37: in press.

Dyurgerov, M.B. 2002. Glacier mass balance and regime: data of measurements and analysis. In: Meier, M. F. and Armstrong, R. (Eds.), Occasional Paper, vol. 55. Institute of Arctic and Alpine Research, University of Colorado, Boulder, CO, $88 \mathrm{pp}$.

Fitzharris, B.B., Hay, J.E. and Jones, P.D. 1992. Behaviour of New Zealand glaciers and atmospheric circulation changes over the past 130 years. The Holocene, 2(2), 97-106.

Greuell, W. 1992. Hintereisferner, Austria: mass balance reconstruction and numerical modelling of the historical length variations. Journal of Glaciology, 38(129), 233-244.

Haeberli, W. and Hoelzle., M. 1995. Application of inventory data for estimating characteristics of and regional climate-change effects on mountain glaciers: a pilot study with the European Alps. Annals of Glaciology, 21, 206-212.

Haeberli, W., Hoelzle, M., Suter, S., and Frauenfelder, R., editors 1998. Fluctuations of glaciers 1990-1995. Paris: IAHS/UNESCO.

Hoelzle, M., Haeberli, W., Dischl, M., and Peschke, W. 2003. Secular glacier mass balances derived from cumulative glacier length changes. Global and Planetary Change, 790, 1-12.

Hooker, B.J., and Fitzharris, B.B. 1999. The correlation between climatic parameters and the retreat and advance of Franz Josef Glacier, New Zealand. Global and Planetary Change, 22, 39-48.

Huybrechts, P., de Nooze, P., and Decleir, H. 1989. Numerical modelling of Glacier $\mathrm{d}^{\prime}$ Argentière and its historic front variations. In Oerlemans, J., editor, Glacier fluctuations and climatic change, Dordrecht: Kluwer Academic Publishers, 373-389.

IPCC, 2001. Climate Change 2001; The Scientific Basis. Contribution of Working Group I to the Third Assessment Report of the Intergovernmental Panel on Climate Change. Cambridge University Press, Cambridge, United Kingdom and New York, NY, USA, 881 pp.

Jóhannesson, T., Raymond, C. and Waddington, E. 1989. Time-scale for adjustment of glaciers to changes in mass balance. Journal of Glaciology, 35(121), 355-369.

Kaser, G. 1999. A review of the modern fluctuations of tropical glaciers. Global and Planetary Change, 22, 93-103.

Krimmel, R.M. 1989. Mass balance and volume of South Cascade Glacier, Washington 1958-1985. In Oerlemans, J. (ed.), Glacier fluctuations and climatic change, Dordrecht: Kluwer Academic Publishers, 193-206.

Krimmel, R.M. 2000. Water, Ice and Meteorological Measurements at South Cascade Glacier, Washington, 1999 Balance Year. USGS WRI-00-4139.

Mackintosh, A.N. and Dugmore, A.J. 2000. Modelling Holocene glacier fluctuations and climatic change in Iceland. Geolines, 11, 142-146.

Mackintosh, A.N. 2000. Glacier fluctuations and climatic change in Iceland. Ph.D. Thesis, Department of Geography, University of Edinburgh, Scotland.

Manley, G. 1959. The late-glacial climate of north-west England. Liverpool and Manchester Geological Journal, 2, 188-215.

Meierding, T.C. 1982. Late Pleistocene glacial equilibrium-line in the Colorado Front Range: A comparison of methods. Quaternary Research, 18, 289-310. 
Nye, J.F. 1965. A numerical method of inferring the budget history of a glacier from its advance and retreat. Journal of Glaciology, 35(121), 355-369.

Oerlemans, J. 1992. Climate sensitivity of glaciers in southern Norway: application of an energy-balance model to Nigardsbreen, Hellstugubreen and Alfotbreen. Journal of Glaciology, 38(129), 223-232.

Oerlemans, J. 1994. Quantifying global warming from the retreat of glaciers. Science, 264, 243-245.

Oerlemans, J. 1997. A flowline model for Nigardsbreen, Norway: projection of future glacier length based on dynamic calibration with the historic record. Annals of Glaciology, 24, 382-389.

Oerlemans, J. and Reichert, B.K. 2000. Relating glacier mass balance to meteorological data by using a seasonal sensitivity characteristic. Journal of Glaciology, 46(152), $1-6$.

Oerlemans, J. 2001. Glaciers and Climate Change. Rotterdam, A.A. Balkema Publishers, $148 \mathrm{pp}$.

Ogilvie, A. 1992. Documentary evidence for changes in the climate AD 1500-1800. In Bradley, R. and Jones, P., editors, Climate since AD 1500 , London: Routdledge, 92-117.

Paterson, W.S.B. 1994. The physics of glaciers. Third edition. Oxford: Elsevier.

Pelfini, M. and Smiraglia, C. 1997. Signals of 20th-century warming from the glaciers in the Central Italian Alps. Annals of Glaciology, 24, 350-354.

Pattyn, F., De Smedt, B., De Brabander, S., Van Huele, W., Agatova, A., Mistrukov, A., and Decleir, H. 2003. Ice dynamics and basal properties of Sofiyskiy Glacier, Altai Mountains, Russia based on DGPS and radio-echo sounding surveys. Annals of glaciology, 37: in press.

Pelto, M.S. and Hedlund, C. 2001. Terminus behavior and response time of North Cascade glaciers, Washington, U.S.A. Journal of Glaciology, 47(158), 497-506.

Perez Moreau, R.A. 1945. Reseña Botánica sobre los Parques Nacionales Nahuel Huapi, Los Alerces y Lanín. Anales del Museo de la Patagonia, 1, 253-276.

Pohjola, V.E. and Rogers, J.C. 1997. Atmospheric circulation and variations in Scandinavian glacier mass balance. Quaternary Research, 47, 29-36.

Porter, S.C. 1975. Equilibrium-line altitudes of late Quaternary glaciers in the Southern Alps, New Zealand. Quaternary Research, 5, 27-47.

Rasmussen, L.A. and Conway, H. 2001. Estimating South Cascade Glacier (Washington, U.S.A.) mass balance from a distant radiosonde and comparison with Blue glacier. Journal of Glaciology, 47(159), 579-588.

Reynolds, J.R. and Young, G.J. 1997. Changes in areal extent, elevation and volume of Athabasca Glacier, Alberta, Canada, as estimated from a series of maps produced between 1919 and 1979. Annals of Glaciology, 24, 60-65.

Savoskul, O.S. 1997. Modern and Little Ice Age glaciers in 'humid' and 'arid' areas of the Tien Shan, Central Asia: two different patterns of fluctuation. Annals of Glaciology, 24, 142-147.

Schmeits, M.J. and Oerlemans, J. 1997. Simulation of the historical variation in length of the Unterer Grindelwaldgletscher, Switzerland. Journal of Glaciology, 43(143), 152-164.

Solomina, O.N. 2000. Retreat of mountain glaciers of northern Eurasia since the Little Ice Age maximum. Annals of Glaciology, 31, 26-30. 
Villalba, R., Leiva, J.C., Rubulls, S., Suarez, J., and Lenzano, L. 1990. Climate, treering, and glacial fluctuations in the Rio Frías valley, Rio Negro, Argentina. Arctic and Alpine Research, 22(3), 215-232.

Wallinga, J. and Van de Wal, S.W. 1998. Sensitivity of Rhonegletscher, Switzerland, to climate change: experiments with a one-dimensional flowline model. Journal of Glaciology, 44(147), 383-393.

Warren, C.R. and Sugden, D.E. 1993. The Patagonian Icefields: A glaciological review. Arctic and Alpine Research, 25(4), 316-331.

Winchester, V. and Harrison, S. 1996. Recent oscillations of the San Quintín and San Rafael glaciers, Patagonian Chile. Geografiska Annaler, 78A, 35-49.

Zuo, Z. and Oerlemans, J. 1997a. Numerical modelling of the historic front variation and the future behaviour of the Pasterze glacier, Austria. Annals of Glaciology, 24, 234-241.

Zuo, Z. and Oerlemans, J. 1997b. Contribution of glacier melt to sea-level rise since AD 1865: a regionally differentiated calculation. Climate Dynamics, 13, 835-845. 


\section{NAWOORD}

Ik wilde een taart bakken, een hele speciale, eentje met een bereidingstijd van wel vier jaar! Ik was niet de eerste die dat zou doen. Er waren in de loop der tijd al tal van andere mensen geweest die zulke taarten hadden gebakken, maar elke taart was weer anders. De taarten verschilden van receptuur, van ingrediënten, van de bakkerij waar zij vandaan kwamen en soms ook van bereidingstijd, maar meestal stond er toch wel zo'n vier jaar voor.

Ik had besloten een ijstaart te gaan bakken en was erg blij toen ik hoorde dat ik dat kon gaan doen in de Utrechtse bakkerij en wel onder toezicht van dè Nederlandse expert in ijs! Hans, zoals deze ijsexpert genoemd werd, wist veel over de lekkerste recepten en ingrediënten van ijstaarten, maar, zei hij, voor een goede ijstaart diende ik voornamelijk zelf op zoek te gaan naar de juiste ingrediënten. Daarnaast, moest ik vooral veel experimenteren met alle bestanddelen die mij geboden werden. In het begin, toen ik nog vooral met de taartbodem bezig was, ging $i k$ toch vaak even bij Hans langs om zijn kennis te raadplegen. Naarmate ik me met de afwerking van de ijstaart ging bezighouden, kon ik het steeds beter alleen. Toch liep ik graag even bij Hans binnen, omdat zijn plezier in het vak aanstekelijk op mij werkte.

Tijdens de eerste jaren werkte naast mij in de bakkerij een jongen met de naam Dan. Hij was enorm behulpzaam in het vertalen van recepten van het Engels in het Nederlands en omgekeerd. Daarnaast zocht Dan altijd met plezier op internet naar de informatie die ik nodig had omtrent de ingrediënten van mijn ijstaart. Ten minste, als hij al niet zelf over deze informatie beschikte.

Tussendoor werden de lagen van mijn ijstaart geproefd, gewikt en gewogen door de andere ijsbakkers van de Utrechtse keuken. Tijdens zo'n keuring kreeg $i k$ vaak goede tips aangereikt hoe ik het geheel nog lekkerder kon maken en over wat er nog aan miste. Zo'n beetje halverwege mijn taart kwam Wouter mij helpen bij het bepalen van de juiste kleur van de poedersuiker. Ook voor en na die tijd wist hij de kwaliteit van mijn ijstaart aanzienlijk te verhogen door mij te attenderen op de nieuwste culinaire hoogstandjes in de ijstaartenbranche, of door mijn baksels voor te proeven en te bekritiseren.

Voor sommige bestanddelen van de taart, vooral voor de beste ijsingrediënten, moest ik op pad naar Zwitserland. Dat waren zeg maar de aangename uitjes tijdens het bakproces. Meestal ging ik niet alleen op reis. De eerste keer bijwoorbeeld ging Hans zelf mee om mij wegwijs te maken in het Zwitserse ijs. De keren daarna was ik met Wim of Henk. Zij wisten als geen ander hoe je als beste het lekkerste Zwitserse ijs kon bepalen met hun verfijnde stukjes techniek.

Terug in Utrecht zat ik dan weer achter het raampje van mijn bakoven te staren. Op de momenten dat mijn oven het leek te begeven, was Marcel er snel bij 
om de nodige reparaties uit te voeren. Gelukkig maar, want ik wist niet veel van ovens en heb er uiteindelijk drie versleten om mijn ijstaart te kunnen bakken.

De Utrechtse bakkerij bestond niet alleen uit bakkers van ijstaarten. Er waren er ook die gespecialiseerd waren in watertaarten en luchtig gebak. Tijdens de pauzes wisselden we onderling de beste recepten en lekkerste ingrediënten uit, maar we kletsten ook wel eens over niets. Dit gebeurde soms ook na een week van bakken onder het genot van een biertje.

Na een dag van hard werken was het altijd heerlijk om weer thuis te komen bij Bas. Meestal had hij al een lekker maaltje voor mij gekookt en zat hij klaar om de heetste nieuwtjes van de Utrechtse bakkerij te horen. Hij voorkwam dat ik me te dik maakte om mijn ijstaart. Zijn groot optimisme, zijn geruststellende woordjes van 'het komt wel goed' en zijn tal van activiteiten waarin hij mij betrok, gaven mij de energie die ik nodig had voor het bakken van mijn ijstaart.

Mijn lieve ouders genoten ook volop mee van mijn ijstaart en wilden graag alles van de nieuwste Zwitserse ijssoorten weten. Zij hadden er het volste vertrouwen in dat mijn ijstaart prachtig en lekker zou worden en steunden mij onvoorwaardelijk in de afwegingen die ik daarbij moest maken: onmisbare ingrediënten voor het laten slagen van een taart! Toch dreigde mijn taart soms in te zakken of vond ik hem echt nergens naar smaken. Op zulke momenten kwam mijn wonderdokter Janneke in actie. Met haar doortastende en verfrissende kijk op mijn werk, wist zij mijn taart weer tot een hemels gerecht om te toveren.

En uiteindelijk is mijn ijstaart gelukt, met dank aan mijn collegabakkers, familie en vrienden. 3 december wordt hij opgediend.

Hans, Bas, pap, mam, Margreet, Rob, Janneke, Jurgen, Francien, Marieke, Erik, Kees, Baldewijn, Nicole, Robert, Coen, Sylvie, Ron, Ivonne, Sigrid, Josephine, Natalie, Karen, Wouter, Marlies, Jan, Hanny, Bruce, Dan, Nicole, Andrew, Wim, Henk, Marcel, Michiel, Guy, Arjan, Ellen, Yvonne, Dirk, Jojanneke, Richard, Han, Carleen, Michiel, Elise, Karsten, Ottolien, Mark, Wim, Liesbet, Inge, Janine, Faezeh, Carina, Lianke, Martijn, Laura, Roderik, Marianne, Keith, Angie, Regine, Wouter, Helmut, Renji, Gerd, Aleth, Greg en Martijn, ik wil jullie ontzettend bedanken voor het nuttige commentaar, de begeleiding, de goede ideeën, de betrokkenheid, het vertrouwen, de discussies, de gezelligheid, de samenwerking, de leuke werksfeer, de steun, de liefde, de vriendschap, de afleiding en de relativering! 


\section{CURriculum VitAE}

Lisette Klok werd geboren op 15 maart 1976 in Bennekom. Op de zandgronden van de Veluwe groeide zij op. Zij doorliep haar middelbare schoolperiode aan het Christelijk Streeklyceum te Ede en in 1994 werd haar het VWO-diploma overhandigd. Toen verhuisde zij naar de uiterwaarden van Wageningen voor de studie Bodem, Water en Atmosfeer aan de toenmalige Landbouw Universiteit. Zij specialiseerde zich in meteorologie en volgde daarvoor colleges aan de Universiteit van Reading. Lisette liep stage bij de Klimatologische Dienstverlening van het KNMI. Haar eerste afstudeervak betrof een onderzoek naar de vorming en duur van dauw in een leliegewas. Aan de ETH van Zürich onderzocht zij in het kader van een tweede afstudeervak de afvoer van het smeltwater van de Rhonegletsjer. In september 1999 studeerde zij Cum Laude af. Gelijk daarna startte zij haar promotieonderzoek aan het IMAU (Instituut voor Marien en Atmosferisch onderzoek Utrecht). Ze werd begeleid in haar onderzoek naar de reactie van gletsjers op klimaatsverandering door Prof. J. Oerlemans. Gelukkig speelde het onderzoek zich niet alleen af achter de computer, maar deed zij ook veldwerk op de Morteratschgletsjer in Zwitserland. Andere leuke reisjes naar het buitenland maakte zij voor cursussen (Karthaus en Lapland) en conferenties (Nice, Innsbruck, Oslo en Zürich).

Lisette Klok was born on the 15th of March, 1976 in Bennekom, and grew up on the sandy soils of the Veluwe. She attended her secondary school at the Christelijk Streekyceum in Ede and completed her VWO education in 1994. Then, she moved to the floodplain of the Rhine by Wageningen for the study Soil, Water and Amosphere at the Agricultural University of that time. She specialised in meteorology and attended lectures at the University of Reading. She did a work placement at the Climatological Services Division of the KNMI. Her first graduation project included a study on dew formation and duration in a lily canopy. As a secondary graduation project, she investigated the melt water discharge of the Rhone glacier at the ETH in Zürich. She graduated Cum Laude in September 1999. Immediately afterwards, she started her PhD-research at the IMAU (Institute for Marine and Atmospheric research, Utrecht). Prof. J. Oerlemans supervised her research on the response of glaciers to climate change. Fortunately, her research not only contained computer work, but also field investigations on Morteratsch glacier in Switzerland. She enjoyed other foreign trips for study courses (Karthaus and Lapland) and conferences (Nice, Innsbruck, Oslo and Zürich). 


\section{LIST OF PUBLICATIONS}

Klok, E.J., Jasper, K., Roelofsma, K.P., Gurtz, J. and Badoux, A. 2001. Distributed hydrological modelling of a heavily glaciated Alpine river basin. Hydrological Sciences Journal, 46(4), 553-570.

De Ruijter de Wildt, M.S., Klok, E.J. and Oerlemans, J. 2002. Reconstruction of the mean specific mass balance of Vatnajökull (Iceland) with a Seasonal Sensitivity Characteristic. Geografiska Annaler, 85 A(1), 57-72.

Oerlemans, J. and Klok, E.J. 2002. Energy balance of a glacier surface: analysis of AWS data from the Morteratschgletscher, Switzerland. Arctic, Antarctic and Alpine Research, 34(123), 115-123.

Klok, E.J. and Oerlemans, J. 2002. Model study of the spatial distribution of the energy and mass balance of Morteratschgletscher, Switzerland. Journal of Glaciology, 48(163), 505-518.

Klok, E.J. and Oerlemans, J. 2003. Deriving historical equilibrium-line altitudes from a glacier length record by linear inverse modelling. The Holocene, 13(3), 343-351.

Klok E.J., Greuell, W. and Oerlemans, J. 2003. Temporal and spatial variation of the surface albedo of Morteratschgletscher, Switzerland, as derived from 12 Landsat images. Journal of Glaciology, accepted.

Oerlemans, J. and Klok, E.J. Effect of summer snowfall on glacier mass balance. Annals of Glaciology, accepted.

Klok, E.J. and Oerlemans, J. 2003. Climate reconstructions derived from global glacier length records. Arctic, Antarctic and Alpine Research, submitted.

Klok, E.J. and Oerlemans, J. 2003. Modelled climate sensitivity of the mass balance of Morteratschgletscher and its dependence on albedo parameterisation. International Journal of Climatology, submitted

\section{Non-reviewed}

Klok, E.J. 1998. Indices die de variabiliteit en de extremen van het klimaat beschrijven. Technical report; TR-211, KNMI, De Bilt.

Klok, E.J. and Roelofsma, K.P. 1999. Modelling of glacier and snow melt processes within the hydrological catchment model WaSiM-ETH. Rapport 85, Sectie Waterhuishouding, Wageningen Universiteit. 